ESRI

RESEARCH

SERIES

NUMBER 116

December

2020

\section{PATHWAYS TO CITIZENSHIP THROUGH NATURALISATION IN IRELAND}

SARAH GROARKE AND RÓISÍN DUNBAR

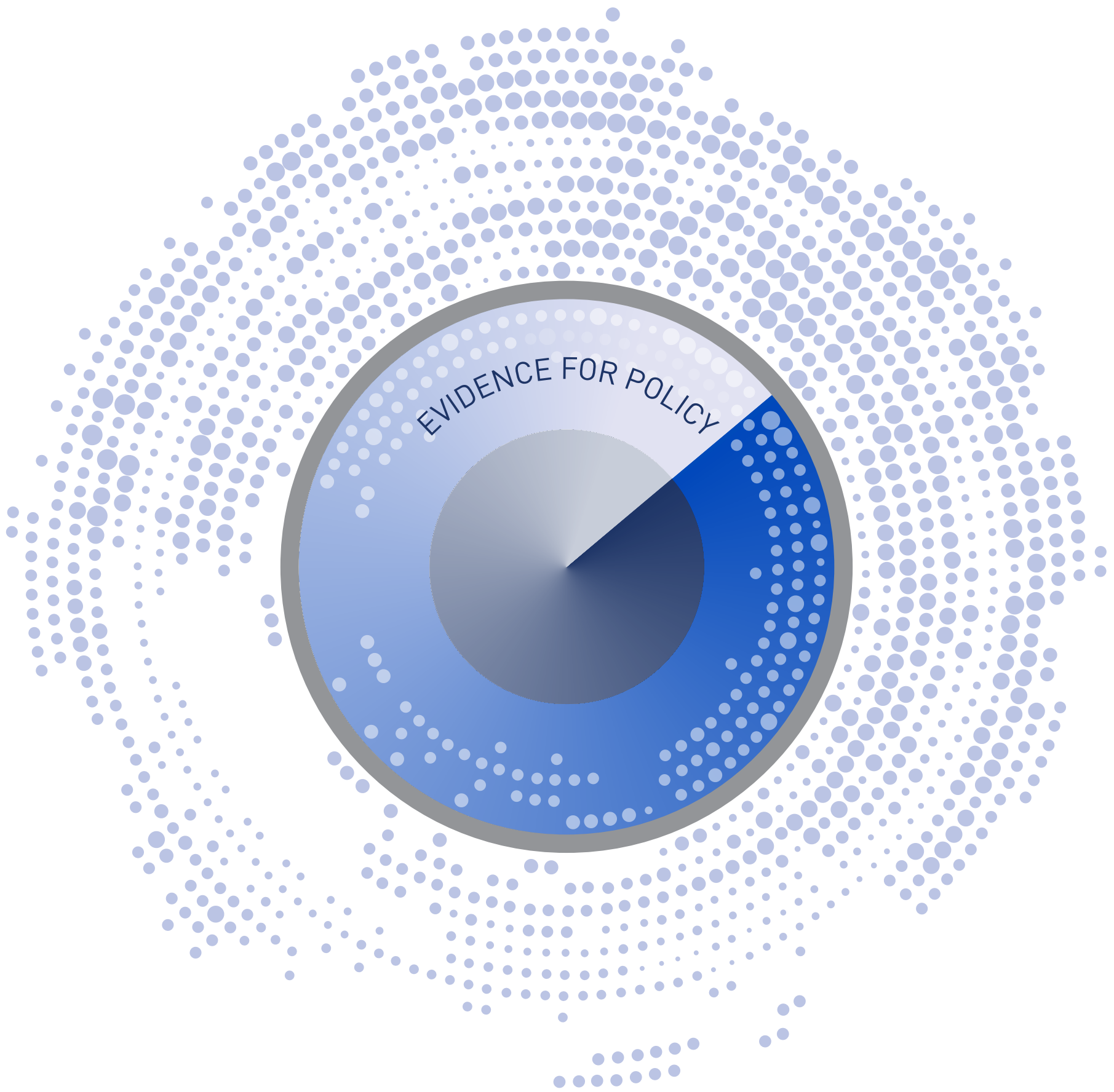

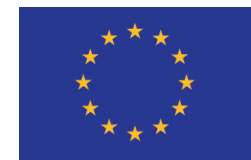

EMN Ireland is funded by the European Union's Asylum, Migration and Integration Fund and cofunded by the Department of Justice
An Roinn Dlí agus Cirt Department of Justice
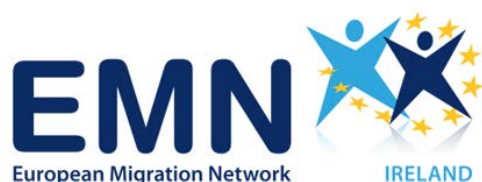

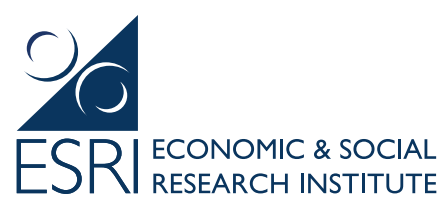




\section{PATHWAYS TO CITIZENSHIP THROUGH NATURALISATION IN IRELAND}

Sarah Groarke

Róisín Dunbar

December 2020

\section{RESEARCH SERIES}

\section{NUMBER 116}

Available to download from www.esri.ie

(C) The Economic and Social Research Institute

Whitaker Square, Sir John Rogerson's Quay, Dublin 2

ISBN 978-0-7070-0549-2

https://doi.org/10.26504/rs116

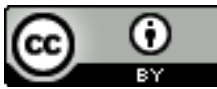

This Open Access work is licensed under a Creative Commons Attribution 4.0 International License (https://creativecommons.org/licenses/by/4.0/), which permits unrestricted use, distribution, and reproduction in any medium, provided the original work is properly credited. 


\section{ABOUT THE ESRI}

The mission of the Economic and Social Research Institute is to advance evidencebased policymaking that supports economic sustainability and social progress in Ireland. ESRI researchers apply the highest standards of academic excellence to challenges facing policymakers, focusing on 12 areas of critical importance to 21st Century Ireland.

The Institute was founded in 1960 by a group of senior civil servants led by Dr T.K. Whitaker, who identified the need for independent and in-depth research analysis to provide a robust evidence base for policymaking in Ireland.

Since then, the Institute has remained committed to independent research and its work is free of any expressed ideology or political position. The Institute publishes all research reaching the appropriate academic standard, irrespective of its findings or who funds the research.

The quality of its research output is guaranteed by a rigorous peer review process. ESRI researchers are experts in their fields and are committed to producing work that meets the highest academic standards and practices.

The work of the Institute is disseminated widely in books, journal articles and reports. ESRI publications are available to download, free of charge, from its website. Additionally, ESRI staff communicate research findings at regular conferences and seminars.

The ESRI is a company limited by guarantee, answerable to its members and governed by a Council, comprising 14 members who represent a cross-section of ESRI members from academia, civil services, state agencies, businesses and civil society. The Institute receives an annual grant-in-aid from the Department of Public Expenditure and Reform to support the scientific and public interest elements of the Institute's activities; the grant accounted for an average of 30 per cent of the Institute's income over the lifetime of the last Research Strategy. The remaining funding comes from research programmes supported by government departments and agencies, public bodies and competitive research programmes.

Further information is available at www.esri.ie 


\section{THE AUTHORS}

Sarah Groarke was a Policy Officer at the Irish National Contact Point of the European Migration Network (EMN Ireland), within the ESRI. Róisín Dunbar was an Intern at EMN Ireland.

\section{ACKNOWLEDGEMENTS}

In compiling this study, valuable assistance was received from representatives of Department of Justice. Thank you also to Catherine Cosgrave, Immigrant Council of Ireland. We would like to thank the internal and external reviewers for their review of the report and helpful suggestions. Thanks are also due to our colleagues Emma Quinn and Frances McGinnity for their guidance. Finally, we would also like to thank Sarah Burns for managing the publication of the report and Anna de Courcy for copy-editing the report.

\section{ABOUT THIS REPORT}

This EMN Ireland study looks at the conditions and procedure for acquiring citizenship through naturalisation in Ireland. The report builds on information gathered by way of a common template for an EU-level synthesis report Pathways to citizenship for third-country nationals in the EU, which is available on www.emn.ie and www.ec.europa.eu/emn.

This report has been accepted for publication by the Institute, which does not itself take institutional policy positions. All ESRI Research Series reports are peer reviewed prior to publication. The authors are solely responsible for the content and the views expressed. 



\section{TABLE OF CONTENTS}

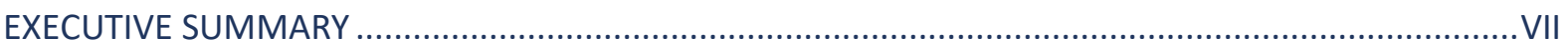

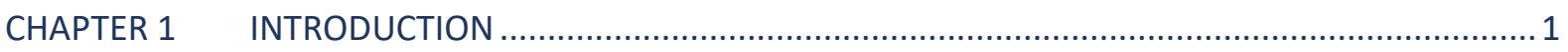

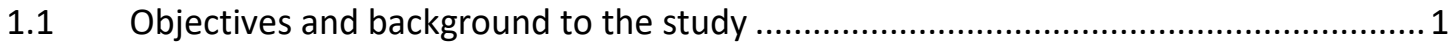

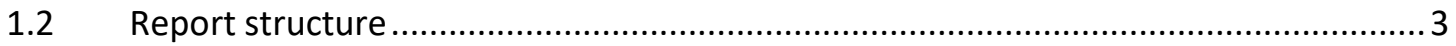

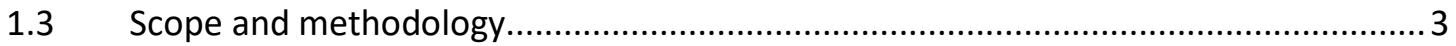

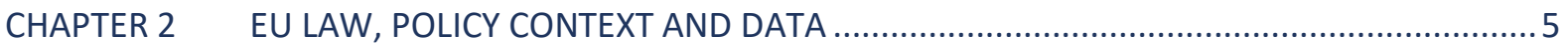

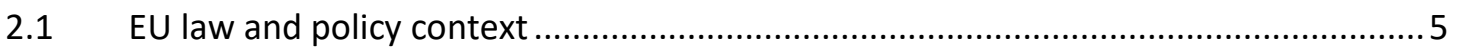

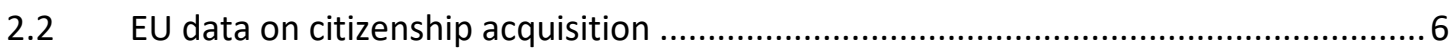

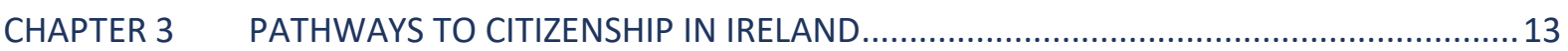

3.1 Modes of citizenship acquisition in Ireland............................................................ 13

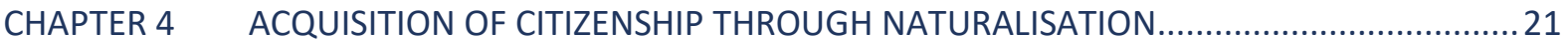

4.1 Conditions for the acquisition of citizenship through naturalisation .........................21

4.2 Naturalisation conditions for specific groups …..................................................... 44

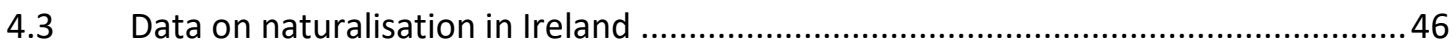

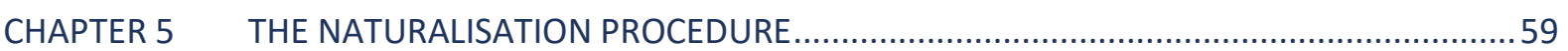

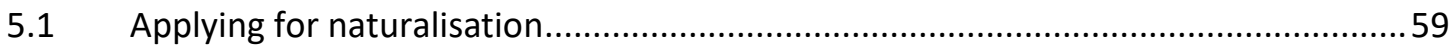

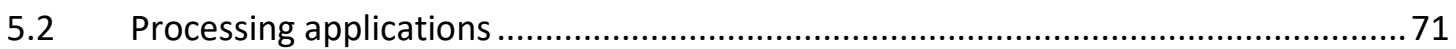

5.3 Negative decisions and judicial review .....................................................................

$5.4 \quad$ Revocation of a certificate of naturalisation .............................................................. 79

5.5 Measures adopted during COVID-19 restrictions ..................................................... 82

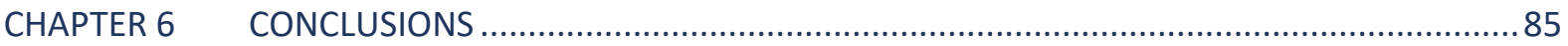

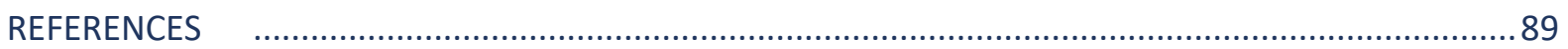

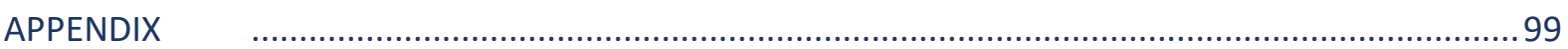




\section{LIST OF TABLES}

Table 4.1 Applications for naturalisation refused 2014-2018

Table 4.2 Acquisition of citizenship through naturalisation on the basis of marriage or civil partnership in Ireland 2014-2018 .56

Table 4.3 Modes of naturalisation of children in Ireland 2014-2018 57

Table 4.4 People with refugee status who naturalised in Ireland 2014-2018. .57

Table A.1 Naturalisation applications received and certificates issued in Ireland 2006-2018 ...99

\section{LIST OF FIGURES}

Figure 2.1 Acquisition of citizenship of an EU Member State 1998-2018 ................................. 7

Figure 2.2 Acquisition of citizenship of an EU Member State by nationality 2014-2018 ............. 8

Figure 2.3 Naturalisation rate of EU and non-EU nationals in EU Member States 2018 ............10

Figure 4.1 Naturalisation applications received and certificates issued in Ireland 2006-2018 ...49

Figure 4.2 Acquisition of citizenship by EU and non-EU nationality in Ireland 2014-2018_........52

Figure 4.3 Acquisition of citizenship by sex and EU/Non-EU nationality in Ireland 2014-2018 ..54

Figure 4.4 Acquisition of citizenship by age and EU/Non-EU nationality in Ireland 2014-2018..55 


\section{ABBREVIATIONS AND IRISH TERMS}

$\begin{array}{ll}\text { An Garda Síochána } & \text { Irish police } \\ \text { CJEU } & \text { Court of Justice of the European Union } \\ \text { Dáil } & \text { Lower house of the Irish parliament } \\ \text { EEA } & \text { European Economic Area, which comprises the EU Member } \\ & \text { States plus Iceland, Liechtenstein and Norway } \\ \text { EMN } & \text { European Migration Network } \\ \text { EU } & \text { European Union } \\ \text { INIS } & \text { Irish Naturalisation and Immigration Service } \\ \text { ISD } & \text { Immigration Service Delivery } \\ \text { NGO } & \text { Non-governmental organisation } \\ \text { Oireachtas } & \text { Irish parliament } \\ \text { PPSN } & \text { Personal Public Service Number } \\ \text { Seanad } & \text { Upper house of the Irish parliament } \\ \text { UN } & \begin{array}{l}\text { United Nations } \\ \text { UNHCR }\end{array}\end{array}$





\section{EXECUTIVE SUMMARY}

This report collates information and data on the acquisition of citizenship through naturalisation in Ireland. Naturalisation, which refers to the acquisition of citizenship after birth on the basis of residence in a country, is the primary means through which migrants and people with a migrant background may acquire citizenship. The Irish Nationality and Citizenship Act 1956 (as amended) governs the acquisition of Irish citizenship, including through naturalisation.

In order to be eligible to apply for citizenship through naturalisation, an applicant must be 18 years of age or born in Ireland, must generally have five years' residence in the State, must be of 'good character', must intend to reside in Ireland, and must make a declaration of fidelity to the nation and loyalty to the State.

\section{DATA}

The number of people applying for naturalisation in Ireland grew rapidly between 2008 and 2011, reflecting the rise in the number of people who had immigrated in the early 2000s becoming eligible to apply for citizenship. The number of naturalisation certificates issued increased significantly between 2011 and 2014, peaking at over 25,000 in 2012, following the introduction of processing improvements that led to a significant backlog of cases being cleared. Since then, the number of applications made, and certificates issued, has decreased steadily. While most people that acquire Irish citizenship through naturalisation are non-EU nationals, the number of EU nationals acquiring citizenship through naturalisation has increased in recent years.

Data on the number of people applying for, and acquiring, citizenship, published by the Department of Justice and Equality (the Department), have become more detailed in line with commitments in the Migrant Integration Strategy 2017-2020. Data were first disaggregated by nationality in 2015, by age in 2017 and by sex in 2018.

\section{AGE CONDITION}

To apply for naturalisation, an applicant must be 18 years of age, or a child born in Ireland. ${ }^{1}$ Children who were not born in Ireland are eligible to apply for naturalisation if they are of 'Irish descent or associations' or their parent has been granted citizenship through naturalisation. An application for a child must be made by the child's parent, legal guardian or a person acting in loco parentis. A recent judgment of the High Court held that while the parent, guardian or person acting 
in loco parentis makes the application, it is the child that must satisfy the conditions for naturalisation. ${ }^{2}$

\section{RESIDENCE CONDITION}

An applicant must have a total 'reckonable' residence of five years during the previous nine years, including one year of 'continuous residence' prior to the application. ${ }^{3}$ Spouses and civil partners of Irish citizens may apply for naturalisation after three years' residence. ${ }^{4}$

A 'six-week rule' operates on an administrative basis, in order to provide for shortterm and temporary absences from the State during the year of continuous residence prior to application. In July 2019, the discretionary six-week rule was found by the High Court to be unlawful. The High Court held in Jones v Minister for Justice and Equality ${ }^{5}$ that 'continuous residence' means unbroken and uninterrupted residence, thus no absence is legally allowed. The judgment was appealed by the applicant, following which the Court of Appeal held that the High Court judgment was 'unworkable, overly literal, unduly rigid and gives rise to an absurdity'. ${ }^{6}$ The Court of Appeal held that the six-week rule was reasonable and pragmatic and 'facilitates flexibility, clarity and certainty' in establishing how the continuous residence requirement must be satisfied by naturalisation applicants. Some practitioners highlight that the application of the six-week rule still lacks clarity.

\section{GOOD CHARACTER CONDITION}

The Minister must be satisfied the applicant is of 'good character'.7 'Good character' is not defined and no guidelines on its interpretation have been published. Applicants must supply information on convictions or civil judgments made against them in the State or any other country and must indicate if they have been the subject of a Garda investigation in Ireland, including where they were not charged with any offence. The Department obtains reports from An Garda Síochána and may obtain reports from other government departments and agencies in assessing the applicant's 'good character'. Research conducted by the Immigrant Council of Ireland highlighted that the application of the 'good character' requirement gives rise to uncertainty for naturalisation applicants (Cosgrave, 2011).

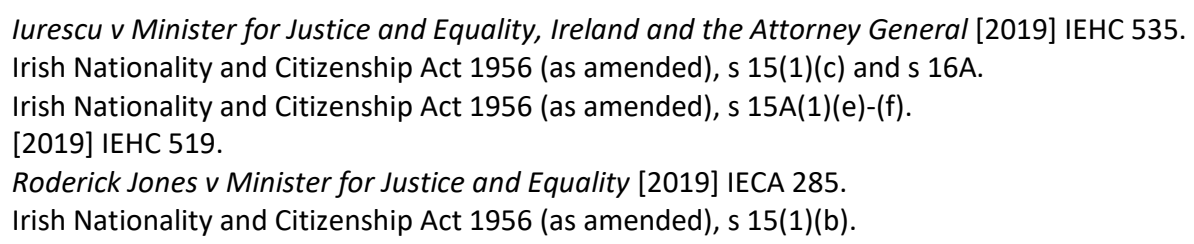




\section{APPLICATION AND FEES}

Application forms must be submitted by post, along with original passports, certified copies and, where necessary, certified translations, of supporting documentation, such as proof of the applicant's identity and nationality, proof of residence and sources of income.

All applicants are required to pay a $€ 175$ application fee and, if granted citizenship, a certification fee: the adult certification fee is $€ 950$, while a reduced fee of $€ 200$ applies for a widow/widower of an Irish citizen and children. Refugees and stateless persons are exempt from paying the certification fee. Out of 24 EU Member States examined in the EMN study on citizenship, Ireland is among the four EU countries that reported the highest naturalisation fees (EMN, 2020a).

\section{DECISION-MAKING PROCESS}

The decision-making process is made up of four stages. First, the identity of the applicant is verified, usually through their passport. The second stage involves assessing whether the applicant has satisfied the residence requirement. Thirdly, the good character assessment is carried out with An Garda Síochána. The final stage of the process is the citizenship ceremony, which facilitates physical verification of the applicant and the applicant's declaration of fidelity to the State.

Concerns around processing delays have been highlighted in parliamentary debate, by NGOs and in the media. Since 2013, the Department has reported that in general it takes six months for an application to be processed from the date it is received to the date a decision is made. In October 2020, the Department reported that it takes 12 months for a straightforward application to be processed, following significant processing delays arising from the outcome of the High Court judgment in Jones v Minister for Justice and Equality in 2019, and restrictions put in place in the context of the COVID-19 pandemic. ${ }^{8}$

\section{NEGATIVE DECISIONS}

The Department reported that failure to satisfy the 'good character' requirement, inability to meet the residence criteria and marriages of convenience are among the top reasons for refusal of a naturalisation application. ${ }^{9}$ Refusals have generally been low in number in recent years, however the ratio of applications refused to certificates issued increased from 6 per cent to 15 per cent in 2018. An appeal

$8 \quad$ Immigration Service Delivery, 'Become an Irish Citizen by Naturalisation: Processing', www.irishimmigration.ie/citizenship/become-an-irish-citizen-by-naturalisation/\#processing (accessed 23 September 2020).

$9 \quad$ Interview with Citizenship Division, Immigration Service Delivery, Department of Justice and Equality, July 2019. 
mechanism for naturalisation decisions does not exist in Ireland, which is unusual in an EU context.

The courts have held that the Minister has a duty to provide reasons to unsuccessful applicants. In September 2020, a Single Person Committee was established to examine the disclosure of material relied upon by the Minister in cases where applications are refused on the basis of national security concerns.

\section{REVOCATION OF CITIZENSHIP}

The State can revoke the citizenship of naturalised Irish citizens in certain circumstances, such as where citizenship was procured by fraud, misrepresentation, or concealment of material facts or where the naturalised citizen is deemed to have failed in their duty of fidelity to the nation and loyalty to the State. The number of revocations is very low, with five revocations reported in the past ten years. In 2018, the Minister established a three-person Committee of Inquiry to consider revocations of naturalised citizens. However, in 2020, the Supreme Court held that the current provisions for revocation of a naturalisation certificate are unconstitutional. ${ }^{10}$ 


\section{CHAPTER 1}

\section{Introduction}

\subsection{OBJECTIVES AND BACKGROUND TO THE STUDY}

Citizenship is a concept that has a variety of meanings in different contexts (Bauböck, 2006), but is generally understood to be a status that marks an individual's legal bond with a State and membership of that community. Access to citizenship provides non-nationals with the full range of rights enjoyed by citizens of the host country. For example, while all residents in Ireland may stand and vote in local elections, regardless of nationality, only Irish and UK citizens have a right to vote in general elections in Ireland, and only Irish citizens have a right to stand in general elections. Access to Irish citizenship has an important European Union (EU) dimension, as granting the citizenship of an EU Member State provides access to EU citizenship, and thus to a range of rights, including the right to move and reside freely within the EU. EU nationals residing in Ireland also have the right to vote and stand as candidates in elections to the European Parliament in Ireland (Coutts, 2018).

Nationals of countries outside the EU or European Economic Area (EEA) ${ }^{11}$ in particular may have a strong incentive to acquire citizenship in Ireland, as citizenship provides security of residence and the freedom to live and work in Ireland without restriction. The majority of public sector jobs are not open to non-EU nationals and are restricted to Irish and EU citizens only (see Arnold et al., 2019). Non-EU nationals resident in Ireland are also subject to international student fees for accessing third-level education.

As citizenship status provides non-nationals with equal rights to participate in democratic and public life, access to citizenship is viewed as an important part of the integration process. Citizenship acquisition is not only a result of integration, but can also further improve social, economic and political integration (Huddleston et al., 2013). Acquisition of citizenship is viewed by some commentators as promoting immigrants' sense of belonging and identification with the host country (Liebig and Von Haaren, 2011; Simonsen, 2017). International research on the labour-market outcomes of naturalised and non-naturalised immigrants has typically found that having the citizenship of the host country is associated with better labour-market outcomes for immigrants (Liebig and Von Haaren, 2011; Hoxhaj et al., 2019). Analysis conducted by McGinnity et al. (2020a) on migrants in

11 The European Economic Area (EEA) comprises the Member States of the EU and Iceland, Liechtenstein and Norway. Different rules concerning immigration and residence permissions apply to persons from within and outside the EEA. For the purposes of this study, reference to EU/non-EU nationals is taken to include/exclude EEA nationals. 
Ireland found that Irish citizenship has a strong and statistically significant effect on occupational attainment and is particularly associated with lower unemployment rates among non-EU nationals.

Policy statements on integration made by the Irish government have highlighted citizenship as a key measure to facilitate the integration of migrants in the host society. In Ireland's first Ministerial statement on integration, Migration Nation A Statement on Integration Strategy and Diversity Management, the government stated that a formal pathway to long-term residence and citizenship is among the key actions required to achieve migrant integration (Office of the Minister for Integration, 2008). Ireland's Migrant Integration Strategy 2017-2020 sets out a series of actions to support the migrant integration process, including actions aimed at supporting access to citizenship and long-term residence (Department of Justice and Equality, 2017).

Naturalisation, which refers to the acquisition of citizenship after birth on the basis of residence in a country, is the primary means through which migrants and people with a migrant background may acquire citizenship. The EU-wide study Pathways to citizenship for third-country nationals in the EU examines naturalisation law and policy in EU Member States. The study found that while naturalisation conditions and procedures vary, naturalisation tends to be a lengthy and costly process, with limited available support, across the EU (EMN, 2020a).

In Ireland, the acquisition of citizenship, including through naturalisation, is governed by the Irish Nationality and Citizenship Act 1956 (as amended). To acquire citizenship through naturalisation an individual must apply to the Minister for Justice and Equality for a certificate of naturalisation. In order to be eligible to apply for citizenship through naturalisation, an applicant must generally have five years' residence in the State, must be of 'good character', must intend to reside in Ireland, and must make a declaration of fidelity to the nation and loyalty to the State.

The eligibility conditions for naturalisation in Ireland are viewed favourably compared to other countries in the EU by international commentators (Goodman, 2010; Bauböck et al., 2013; Huddleston et al., 2015). For example, applicants are not required to renounce citizenship of their country of origin in order to acquire Irish citizenship, nor do they need to 'prove' a certain degree of integration, such as proficiency in the national language or civic knowledge of the country (EMN, 2020a). Goodman (2010) classifies Ireland as among an 'enabling' group of countries, that view citizenship as a means of acquiring equal status and rights and 'enabling' instead of 'rewarding' integration. Nevertheless, NGOs and legal practitioners have raised concerns relating to the naturalisation procedure, particularly the discretionary nature of the decision-making process, long processing delays and application costs, which may hinder access to citizenship 
(Cosgrave, 2011; Becker and Cosgrave, 2013; Migration Policy Group and Immigrant Council of Ireland, 2013; Huddleston et al., 2015).

This report examines the acquisition of citizenship through naturalisation in Ireland. It focuses on the conditions for naturalisation set out in Irish citizenship law and policy, in addition to the application procedure and the decision-making process. Reference to other EU Member States is made throughout the report to provide a comparative overview of policies and practice across the EU. In light of recent developments in Irish law, the report also includes a brief overview of the approach to revocation of citizenship acquired through naturalisation in Ireland.

\subsection{REPORT STRUCTURE}

Section 1.3 sets out the scope of the report and the report's methodology. Chapter 2 discusses EU law and policy relevant to citizenship acquisition and presents some EU data on the acquisition of citizenship in EU Member States. Chapter 3 sets out Irish law and policy on citizenship acquisition, situating naturalisation within the broader citizenship framework. Chapter 4 examines the conditions that apply to the acquisition of citizenship through naturalisation in Ireland and discusses data on naturalisation trends in Ireland. Chapter 5 provides an overview of the naturalisation application and decision-making procedure. Chapter 5 also includes a brief discussion of measures adopted in response to the COVID-19 pandemic in 2020. Lastly, Chapter 6 draws the main conclusions from the study.

\subsection{SCOPE AND METHODOLOGY}

This report collates information and data on the acquisition of citizenship through naturalisation in Ireland. Naturalisation is defined as any mode of acquisition after birth of a citizenship not previously held by the target person that requires an application by this person or their legal agent as well as an act of granting citizenship by a public authority (EMN, 2018).

The EU-wide study Pathways to citizenship for third-country nationals in the EU covers third-country nationals, or nationals of countries outside the EU (EMN, 2020a). However, as naturalisation conditions in Ireland do not generally distinguish between EU and non-EU nationals, reference to naturalisation applications should be interpreted as encompassing all non-Irish nationals. Reference is specifically made to non-EU nationals where relevant, particularly in relation to data on the acquisition of citizenship and procedural requirements, where these differ depending on an applicant's nationality. Where reference is made in this report to EU Member States, this should be interpreted as including the UK, as the UK was an EU Member State at the time of the study's development. 
The scope of the EU-wide study extended to the most recent policy and legislative developments in each Member State, therefore information on developments in Ireland in 2019 and 2020 are included in the report. Data gathered for the EU-wide study cover the period 2014 to 2018, however this report contains some data prior to 2014 in order to provide an overview of trends in citizenship acquisition over time. While data gathered and presented in this study were correct at the time of publication of the original source, minor changes may have occurred subsequently due to data cleansing and efforts to improve data within the Department of Justice and Equality. ${ }^{12}$ Reference to 'the Department' throughout the report should be read as the Department of Justice and Equality, as this was the name of the Department at the time of writing. ${ }^{13}$

The terms citizenship and nationality are often used interchangeably in law and policy. However, citizenship and nationality may be understood as two distinct concepts. Citizenship describes the particular legal bond between an individual and a state that entails specific legal rights and duties under domestic law. ${ }^{14}$ Nationality can be understood to mean the legal relationship between a person and a state as recognised in international law, and is used in the context of international relations between states and the relation of states to the citizens of other states..$^{15}$ This understanding of citizenship and nationality is adopted in this report.

The report is based on information gathered according to commonly agreed EMN study specifications for the EU-wide study Pathways to citizenship for third-country nationals in the EU. As with all EMN studies, a similar report was produced by the EMN National Contact Point (NCP) in each participating Member State. An EU-wide synthesis report collating information from the national reports of 25 participating EMN NCPs was subsequently published (EMN, 2020a).

For the national report, desk research was undertaken at the outset, including a review of policy documents, academic literature and reports by non-governmental organisations. An interview was undertaken with a representative of Immigration Service Delivery's Citizenship Division within the Department of Justice and Equality. Data were obtained from the Department of Justice and Equality's Research and Data Analytics unit for the period 2014 to 2018. Input was also received from the Immigrant Council of Ireland. The report was internally and externally reviewed.

12 Consultation with Research and Data Analytics unit, Department of Justice and Equality, October 2020.

13 The Department of Justice and Equality has undergone several name changes in recent years: Department of Justice, Equality and Law Reform (1997-2009); Department of Justice and Law Reform (2010); Department of Justice and Equality (2011-2020). Since the writing of the report, the Department's name was altered to the Department of Justice, with effect from 1 November 2020. 


\section{EU law, policy context and data}

\subsection{EU LAW AND POLICY CONTEXT}

European Union (EU) citizenship was formally enshrined in the EU treaties in 1992. The Treaty on the Functioning of the European Union states that any person who holds the citizenship of an EU Member State is automatically an EU citizen. ${ }^{16}$ Citizenship of the EU is additional to, and does not replace, national citizenship. ${ }^{17}$

The Court of Justice of the European Union (CJEU) has held that, while it is for each EU Member State to lay down the conditions for the acquisition and loss of citizenship, when exercising powers in the sphere of citizenship, EU Member States must have due regard to EU law. ${ }^{18}$ In particular, the granting of citizenship of a Member State brings with it a set of corresponding EU rights. EU citizens enjoy the right to move and reside freely within the territory of the EU, the right to vote and stand in elections to the European Parliament and municipal elections in the Member State in which they reside, the right to enjoy the protection of the diplomatic and consular authorities of any Member State, and the right to address, and receive a reply from, the EU institutions and bodies in any EU language. ${ }^{19}$

Most EU Member States have signed up to the European Convention on Nationality, which was adopted by the Council of Europe in 1997, and is the main Europe-wide legal instrument relating to citizenship. ${ }^{20}$ The Convention, which entered into force in 2000 , incorporates essential principles applying to nationality, including non-discrimination, the rights of nationals of signatory states and the prevention of statelessness. Ireland is one of only seven EU Member States that have not signed or ratified the 1997 European Convention on Nationality. ${ }^{21}$ Pilgram (2011) suggests Ireland's decision not to sign or ratify the 1997 Convention may be because the Convention's rights-based approach to naturalisation is inconsistent with Ireland's privilege-based principles, and the incompatibility with Irish law of both Article 11 of the 1997 Convention, which prescribes a duty to give reasons for decisions relating to acquisition, retention, loss, recovery or certification of nationality, and Article 12 of the Convention, which prescribes a right to review for decisions on the acquisition and loss of citizenship.

Treaty on the Functioning of the European Union, Article 20(1).

Ibid.

Case C-369/90 Micheletti and Others [1992] ECR I-4329; Case C-135/08 Rottmann [2008] EU:C:2010:104.

Treaty on the Functioning of the European Union, Article 20(2).

The Council of Europe is an international organisation set up to promote democracy and protect human rights and the rule of law in Europe. It comprises 47 countries of Europe, including all EU Member States.

21 Along with Ireland, Belgium, Cyprus, Estonia, Lithuania, Slovenia and Spain have not signed or ratified the European Convention on Nationality. The UK has also not signed or ratified the Convention. 
In its Tampere Council Conclusions in 1999, the EU Council endorsed the objective that long-term legally resident non-EU nationals be offered the opportunity to obtain citizenship of the Member State in which they are resident (Council of the European Union, 1999). The European Commission's Handbook on Integration says that all states have an interest in securing full socio-economic and political inclusion through the recognition of full citizenship for the long-term non-national population, especially for children born in the country (Niessen and Huddleston, 2010).

The European Migration Network study on Pathways to citizenship for thirdcountry nationals in the EU (EMN, 2020a) shows that the conditions and procedures for acquiring citizenship vary widely across EU Member States. It highlights that naturalisation in EU Member States can be a lengthy and costly process, with limited available support, and a positive outcome is not always guaranteed, even where all conditions have been met. Recent years in particular have seen many changes in approach to citizenship policy in a number of EU Member States. An increased focus among EU Member States on the need to facilitate the integration of immigrants has pushed some countries to lower barriers to naturalisation, such as accepting dual citizenship (Mentzelopoulou and Dumbrava, 2018; EMN, 2020a). However, commentators also suggest that citizenship in Europe has become more politicised and citizenship laws are increasingly used to test the integration of immigrants and reinforce official versions of national identity (Mentzelopoulou and Dumbrava, 2018; Vink and de Groot, 2010). The introduction of language and civics requirements attached to citizenship is a particular example of this (Groarke et al., 2020). Such changes tend to reflect the difference in how Member States view citizenship in the context of integration. The EMN (2020a) found that citizenship is expressly seen by nine Member States as the culmination of the integration process, while four Member States, including Ireland, view citizenship primarily as part of, and facilitating, the integration process.

\subsection{EU DATA ON CITIZENSHIP ACQUISITION}

Data on the acquisition of citizenship in EU Member States are reported annually to Eurostat, the statistical office of the EU. EU Regulation 862/2007 on statistics on migration and international protection provides that Member States must provide Eurostat with annual statistics on persons who have acquired citizenship of the Member State, disaggregated by age, sex and former citizenship of the person. ${ }^{22}$

22 Regulation (EC) No 862/2007 of the European Parliament and of the Council of 11 July 2007 on Community statistics on migration and international protection and repealing Council Regulation (EEC) No 311/76 on the compilation of statistics on foreign workers (Regulation 862/2007), Article 3(1)(d). 
Data on citizenship acquisition reported to Eurostat by EU Member States may encompass a variety of modes of citizenship acquisition, including naturalisation. ${ }^{23}$

Figure 2.1 shows the number of persons who acquired citizenship of an EU Member State has gradually increased over the past two decades. ${ }^{24}$ Citizenship acquisition grew by 64 per cent overall from 1998, when 505,481 people acquired citizenship, to 2018 , when 829,274 people acquired citizenship. Acquisition has fluctuated particularly in recent years. In 2012, acquisition of citizenship in the EU totalled 820,826 , which increased by 19 per cent to 979,180 in 2013. Acquisition decreased by 14 per cent to 839,740 in 2015 and increased sharply again by 18 per cent to 993,266 in 2016 . Acquisition subsequently decreased by 17 per cent to 829,274 in 2018.

\section{FIGURE 2.1 ACQUISITION OF CITIZENSHIP OF AN EU MEMBER STATE 1998-2018}

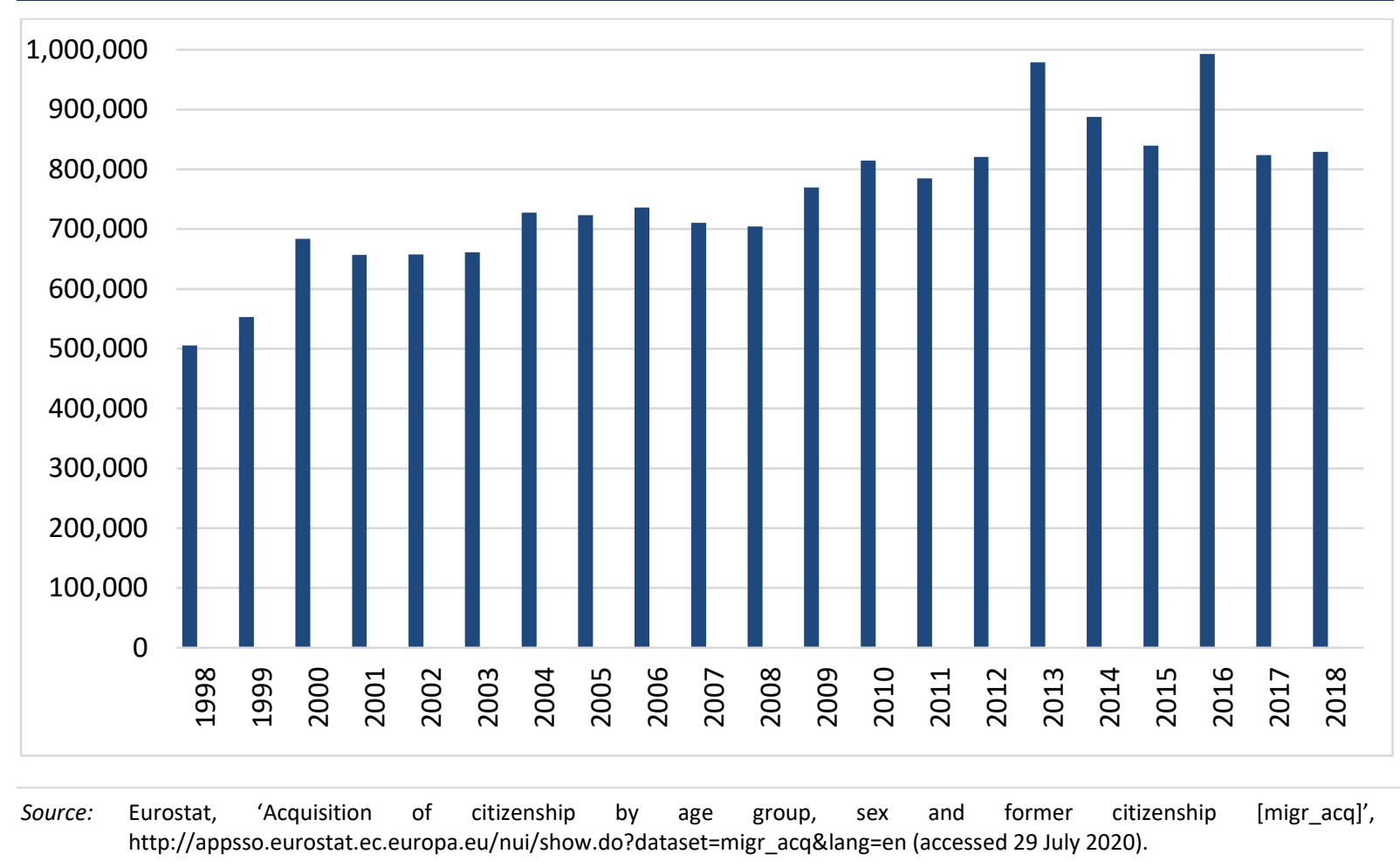

Figure 2.2 shows that the majority of people acquiring citizenship in EU Member States are non-EU nationals. Of those who acquired citizenship of an EU Member State in 2018, 79 per cent were non-EU nationals. However, data show that the number of non-EU nationals acquiring citizenship of an EU Member State

23 Article 2(1)(d) of Regulation 862/2007 defines citizenship as 'the particular legal bond between an individual and his or her State, acquired by birth or naturalisation, whether by declaration, choice, marriage or other means according to national legislation'.

24 Data on EU Member States include data reported by the UK as the UK was an EU Member State during the period in which the data were reported. 
decreased by 16 per cent from 783,270 in 2013 to 656,159 in 2018. ${ }^{25}$ While still low compared to non-EU nationals, the number of EU nationals acquiring citizenship of another EU Member State increased overall by 60 per cent from 95,734 in 2014 to 153,343 in $2018 .^{26}$

\section{FIGURE 2.2 ACQUISITION OF CITIZENSHIP OF AN EU MEMBER STATE BY NATIONALITY 2014-2018}

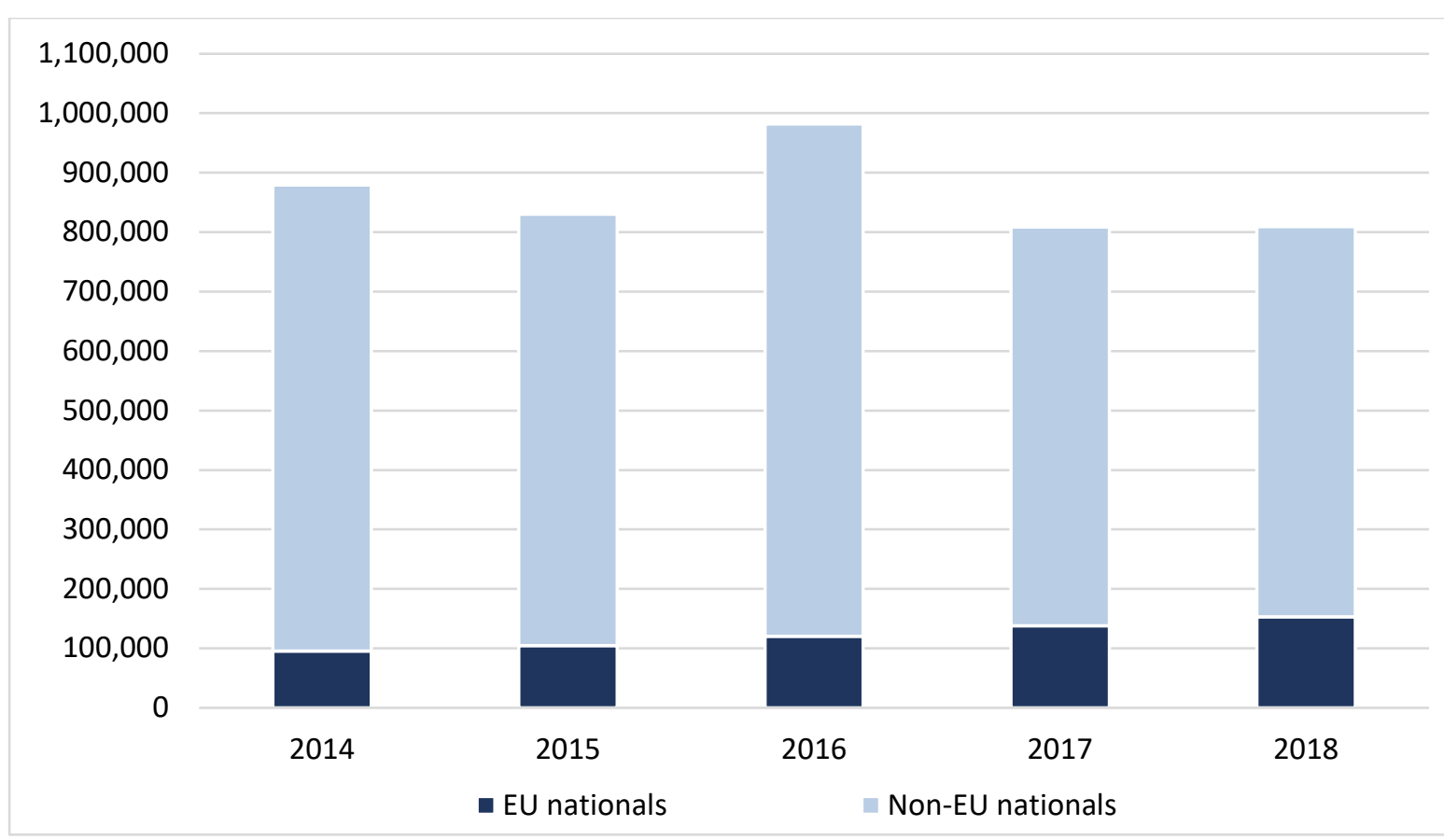

Source: Eurostat, 'Acquisition of citizenship by age group, sex and former citizenship [migr_acq]', http://appsso.eurostat.ec.europa.eu/nui/show.do?dataset=migr_acq\&lang=en (accessed 29 July 2020).

The largest numbers of people acquiring citizenship of an EU Member State between 2014 and 2018 were reported in the UK, Germany, Italy, France, Spain and Sweden. ${ }^{27}$ Citizenship acquisitions in these six countries accounted for 90 per cent of all citizenship acquisitions in EU Member States in $2018 .{ }^{28} \mathrm{~A}$ total of 8,223 people acquired Irish citizenship in 2018, accounting for 1 per cent of all citizenship acquisitions in the EU in 2018. ${ }^{29}$

Eurostat also report on the naturalisation rate of migrants in EU Member States. The naturalisation rate is one of three indicators to measure integration in the active citizenship domain agreed upon in the Zaragoza Declaration conference by EU ministers responsible for integration. ${ }^{30}$ The rates are calculated by Eurostat as

Authors' own calculations using data from Eurostat, 'Acquisition of citizenship by age group, sex and former citizenship [migr_acq]', http://appsso.eurostat.ec.europa.eu/nui/show.do?dataset=migr_acq\&lang=en (accessed 29 July 2020). lbid.

Ibid.

Ibid.

Ibid.

The other two indicators for 'active citizenship' are the share of immigrants holding permanent or long-term residence permits and the share of immigrants among elected representatives (see McGinnity et al., 2019). 
the total number of non-national persons granted citizenship in the reference year, divided by the total estimated resident non-national population. Naturalisation rates capture information on the opportunities to naturalise presented by citizenship policy ${ }^{31}$ and factors such as immigrants' motivation to naturalise (Niessen and Huddleston, 2010; Barrett et al., 2017).

Figure 2.3 shows the naturalisation rate for EU nationals and non-EU nationals acquiring citizenship in EU Member States. Romania (10.9 per cent), Sweden ( 8.78 per cent) and Portugal ( 7.21 per cent) report the highest naturalisation rates among non-EU nationals, while the highest naturalisation rates among EU nationals were reported in Latvia (3.41 per cent), Sweden (3.9 per cent) and Hungary (3.25 per cent).

In Ireland, 1.42 per cent of all non-Irish nationals resident in Ireland acquired Irish citizenship through naturalisation in 2018. As in the majority of other EU Member States, non-EU nationals have a higher naturalisation rate than EU nationals in Ireland, with 3 per cent of non-EU nationals naturalising in Ireland 2018 compared to 0.9 per cent of EU nationals.

One reason put forward for low rates among EU nationals resident in another EU Member State is that EU nationals have relative security of residence and are already entitled to most of the rights granted to national citizens of the host Member State, and thus the incentive to acquire citizenship may be lower than for non-EU nationals (Niessen and Huddleston, 2010; McGinnity et al., 2018a). 
FIGURE 2.3 NATURALISATION RATE OF EU AND NON-EU NATIONALS IN EU MEMBER STATES 2018

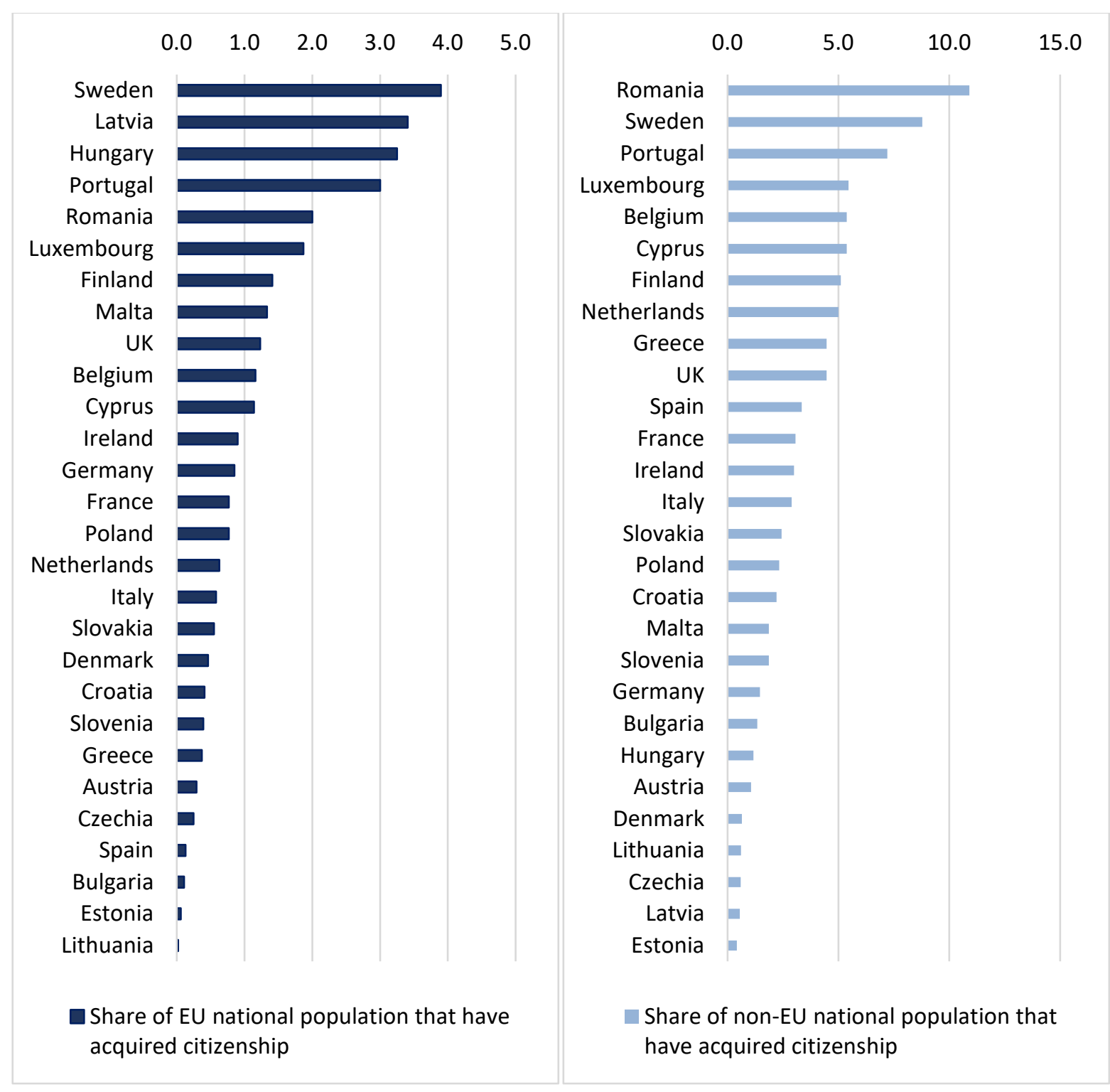

Source: Eurostat, 'Residents who acquired citizenship as a share of resident non-citizens by former citizenship and sex [migr_acqs]', https://appsso.eurostat.ec.europa.eu/nui/show.do?dataset=migr_acqs\&lang=en (accessed 29 July 2020).

The most common countries of origin of non-EU nationals acquiring citizenship in the EU from 2014 to 2018 were Morocco, Albania, Turkey, Brazil, Ukraine, Russia and Algeria (EMN, 2020a). The most common country of origin of EU nationals acquiring the citizenship of another EU Member State in 2018 was Romania, followed by Poland, the UK, Italy, Germany and Bulgaria. ${ }^{32}$

The number of UK nationals acquiring the citizenship of an EU Member State has significantly increased in recent years. Prior to 2016, the total number of UK 
nationals acquiring citizenship of another EU Member State fluctuated between 1,000 and 2,000 per year. However, in 2016 the number of UK nationals that acquired citizenship of another EU Member State increased to 6,689. ${ }^{33}$ The number jumped to 15,054 in 2017 and 16,206 in 2018. ${ }^{34}$ This increase is likely to be related to the outcome of the referendum held in the UK in 2016 to leave the EU.

The number of UK nationals acquiring Irish citizenship through naturalisation also increased during the study period. A total of 51 UK nationals acquired Irish citizenship in 2014, followed by 54 in 2015 and 98 in 2016. The number of UK nationals that naturalised in Ireland significantly increased to 529 in 2017. In 2018, 687 UK nationals acquired Irish citizenship through naturalisation, ${ }^{35}$ representing a sevenfold increase in the number of UK nationals acquiring Irish citizenship through naturalisation since 2016. The proportion of UK nationals acquiring citizenship through naturalisation in Ireland out of all EU Member States also grew, from 1 per cent in 2016 to 4 per cent in 2018. These trends mirror increases in foreign birth registrations and passport applications made by UK nationals since 2016 (McGinnity et al., forthcoming). The number of Irish passport applications made by residents of the UK and Northern Ireland saw a large increase from 2014, when over 23,700 applications were received, to 2018 when over 79,500 applications were received. ${ }^{36}$

33 Authors' own calculations using data from Eurostat, 'Acquisition of citizenship by age group, sex and former citizenship [migr_acq]', http://appsso.eurostat.ec.europa.eu/nui/show.do?dataset=migr_acq\&lang=en.

$34 \quad$ Ibid.

35 Eurostat, 'Acquisition of citizenship by age group, sex and former citizenship [migr_acq]', http://appsso.eurostat.ec.europa.eu/nui/show.do?dataset=migr_acq\&lang=en (accessed 29 July 2020).

36 Parliamentary Question [38983/19], 25 September 2015, available at www.oireachtas.ie/en/debates/question/201909-25/52. 



\section{CHAPTER 3}

\section{Pathways to citizenship in Ireland}

Article 9 of the Constitution of Ireland sets out the basic principles of Irish nationality and citizenship. Article $9.1 .2^{\circ}$ of the Constitution provides that the acquisition and loss of Irish nationality and citizenship shall be determined by law. The Irish Nationality and Citizenship Act 1956 (as amended) (the 1956 Act) governs the acquisition of citizenship in Ireland, including through naturalisation. Citizenship policy is primarily the responsibility of the Department of Justice and Equality (the Department).

This chapter provides an overview of the modes of acquisition of citizenship in Ireland. While the focus of this study is on the acquisition of citizenship by migrants who have no prior ties to Ireland, this chapter situates the naturalisation process within the wider citizenship framework in Ireland.

\subsection{MODES OF CITIZENSHIP ACQUISITION IN IRELAND}

The 1956 Act governs the modes of citizenship acquisition in Ireland. Three primary modes of citizenship acquisition included in the 1956 Act are acquisition of citizenship at birth by descent, acquisition by birth on the island of Ireland, and naturalisation. Additional modes of acquiring citizenship are also provided for in certain circumstances, such as acquisition of citizenship by deserted new-born children, acquisition of citizenship by adopted children, and the granting of citizenship as a token of honour.

This section first addresses the acquisition of Irish citizenship at birth, which is either granted by descent or by birth on the island of Ireland, followed by a discussion of naturalisation and other modes of acquisition.

\subsubsection{Acquisition of Irish citizenship at birth}

\section{The 2004 referendum and the $27^{\text {th }}$ amendment to the Irish Constitution}

The acquisition of citizenship at birth in Ireland is currently premised predominantly on the jus sanguinis principle, which refers to acquisition on the basis of the citizenship of an individual's parents, or acquisition of citizenship by descent. Prior to 2005, citizenship acquisition was based largely on the jus soli principle, which refers to acquisition of citizenship on the basis of the country in which an individual is born. Any person born on the island of Ireland prior to 2005 was thereby automatically entitled to Irish citizenship. This position had been 
incorporated into the Constitution by way of referendum in 1998 to give effect to commitments made under the Good Friday Agreement, and ensured that people born in Northern Ireland could, if they wished, be citizens of Ireland (Honohan, 2010).

In 2004, the government proposed to amend the jus soli entitlement in the Constitution by way of referendum to remove the automatic right to Irish citizenship of children born in Ireland to non-Irish national parents. The reason put forward for this $27^{\text {th }}$ amendment by the then Minister was that:

persons with no substantial links to Ireland, North or South, are arranging their affairs so as to ensure that a child is born within the island of Ireland, thus acquiring, despite the lack of association with either part of the island, an entitlement and birthright to be part of the Irish nation. ${ }^{37}$

The proposal was also made by the government on the grounds of defending the integrity of Irish citizenship and bringing Ireland in line with other EU countries. ${ }^{38}$ The amendment met much opposition, including for a lack of consultation, insufficient consideration of the impact on the rights of a category of children born in Ireland, and absence of statistical evidence of 'citizenship tourism' (see Mullally, 2005; Ryan, 2004; Fanning and Mutwarasibo, 2007; Honohan, 2010). The then Human Rights Commission stated that much of the evidence and rationalisation in support of the proposed amendment was vague or anecdotal and was of the view that the government had not demonstrated that all other means of addressing its concerns, and that were less detrimental to the rights of children, had been exhausted (Human Rights Commission, 2004).

The referendum on the $27^{\text {th }}$ amendment was passed, with 79 per cent of voters in favour of the amendment, and signed into law in June 2004, inserting Article 9.2.1 into the Constitution. Article 9.2.1 $1^{\circ}$ states that a person born in the island of Ireland who does not have at least one parent who is, or is entitled to be, an Irish citizen, is not entitled to Irish citizenship, unless provided for by law. The Irish Nationality and Citizenship Act 2004 was subsequently enacted and provided that any person born in Ireland after 1 January 2005 to non-Irish parents may only obtain citizenship at birth provided at least one of their parents has been legally resident in Ireland for three out of the previous four years prior to their birth. With the focus being on the parents' status prior to the child's birth, the changes to citizenship law represented a shift towards a predominant jus sanguinis approach to citizenship acquisition (Honohan, 2007).

\footnotetext{
37 Houses of the Oireachtas, 'Twenty-seventh Amendment of the Constitution Bill 2004: Second Stage', Dáil Éireann debate, Vol. 583, No. 6, 21 April 2004, available at www.oireachtas.ie/en/debates/debate/dail/2004-04-21/3. 


\section{Current provisions on the acquisition of citizenship at birth by descent}

Acquisition of citizenship by descent is the main basis for the acquisition of Irish citizenship. Irish citizenship law provides that citizenship may be granted to a person whose parent was, or would have been if deceased, an Irish citizen at the time of the person's birth. ${ }^{39}$ The granting of such citizenship is automatic at birth. ${ }^{40}$

Where a person is born outside of Ireland and the parent through whom citizenship is derived was also born outside of Ireland, they are entitled to Irish citizenship provided they register their birth with the Foreign Births Register. ${ }^{41}$ This represents a pathway to Irish nationality among the Irish diaspora, on the condition that each descendant born abroad has their birth registered.

\section{Current provisions on the acquisition of citizenship by birth in the island of Ireland}

Irish citizenship law provides that a child born in the island of Ireland is entitled to Irish citizenship where one or both of their parents is an Irish citizen or a British citizen, or is entitled to live in the Irish State or Northern Ireland without any restriction on their residence. ${ }^{42}$

A child born in the island of Ireland to a parent who is not Irish or British is also automatically entitled to be an Irish citizen if the parent(s) of the child has been resident in Ireland or Northern Ireland for three of the four years before the child's birth. Residence in Ireland illegally, residence as a student and residence as an international protection applicant is not considered 'reckonable' for the purposes of the residence period required.

Such children typically assert their entitlement to Irish citizenship through an application for an Irish passport made on their behalf to the Department of Foreign Affairs and Trade. Non-EU nationals residing in Ireland must submit their child's original birth certificate in the passport application, along with evidence of residence, including their own Residence Permit Card and passport showing residence stamps granting permission to remain in Ireland for three of the four years before the child's birth. ${ }^{43} \mathrm{EU}$ nationals who have resided in Ireland for three years and who wish to apply for an Irish passport for their child born in Ireland, must complete a witnessed 'Form A' declaration of residence and must submit

\footnotetext{
Irish Nationality and Citizenship Act 1956 (as amended), s 7.

Irish Nationality and Citizenship Act 1956 (as amended), s 7(1).

Irish Nationality and Citizenship Act 1956 (as amended), s 7(3).

Irish Nationality and Citizenship Act 1956 (as amended), s 6.

Consultation with Citizenship Division, Immigration Service Delivery, Department of Justice and Equality, January 2020.
} 
evidence of their nationality and residence along with the passport application to the Department of Foreign Affairs and Trade. ${ }^{44}$

A child born in Northern Ireland to a non-EU national who satisfies the three-year residence requirement and wishes to assert their entitlement to citizenship must first apply to the Department of Justice and Equality for a certificate of nationality under section 28A of the 1956 Act. ${ }^{45}$ The child's parent must submit a 'Form C', which is a declaration that the parent was legally resident in Northern Ireland for three out of the four years immediately before the birth of the child. ${ }^{46}$ The parent must also submit the child's birth certificate, the parent's passport showing UK immigration stamps, and two forms of proof of residence for each of the three years of residence claimed. ${ }^{47}$ If the Minister is satisfied that the parent has resided in Ireland for three out of the previous four years, and that the issue of a certificate is necessary in the circumstances of the case, the Minister may issue the applicant a certificate of nationality confirming that the child is entitled to apply for an Irish passport. ${ }^{48}$ As in the case of EU nationals who have resided in Ireland for three years, EU nationals who have resided in Northern Ireland for three years and who wish to apply for an Irish passport for their child born in Northern Ireland, must complete a witnessed 'Form A' declaration of residence and must submit evidence of their nationality and residence along with the passport application to the Department of Foreign Affairs and Trade. ${ }^{49}$ Irish law also provides for the acquisition of Irish citizenship by children born stateless in Ireland. Section 6(3) of the 1956 Act states that a person born in the island of Ireland is an Irish citizen from birth if he or she is not entitled to citizenship of any other country. This provision is in line with the 1961 Convention on the Reduction of Statelessness, which Ireland ratified in $1973 .{ }^{50}$ However, Ireland does not have a formal stateless determination procedure, and the United Nations High Commissioner for Refugees (UNHCR) reported there are significant practical obstacles to establishing a stateless person's entitlement to Irish citizenship under the provisions of the 1956 Act in the absence of a determination procedure (United Nations High Commissioner for Refugees, 2014). Stateless persons may be able to rely on section 28 of the 1956 Act, which provides that any person who claims to be an Irish citizen Act 1956, of residence in the island of Ireland, its islands and seas', available at www.irishimmigration.ie/wpcontent/uploads/2019/11/declaration-form-A.pdf; Irish Nationality and Citizenship Act 1956 (as amended), s 6B(2). Irish Nationality and Citizenship Act 1956 (as amended), s 28A(4).

46 Department of Justice and Equality, 'Form C - Declaration under section 28A of the Act of 1956, by a Parent of a person not of full age in respect of whom a Certificate of Nationality is being sought under section 28 of that Act', available at www.irishimmigration.ie/wp-content/uploads/2019/11/form-CTZ8.pdf. Ibid.

Consultation with Citizenship Division, Immigration Service Delivery, Department of Justice and Equality, January 2020. Department of Justice and Equality, 'Form A - Declaration, under section 6B(2) of the Irish Nationality and Citizenship Act 1956, of residence in the island of Ireland, its islands and seas', available at www.irishimmigration.ie/wpcontent/uploads/2019/11/declaration-form-A.pdf; Irish Nationality and Citizenship Act 1956 (as amended), s 6B(2).

50 Article 1(1) of the 1961 Convention on the Reduction of Statelessness states that a contracting State must grant its nationality to a person born in its territory who would otherwise be stateless. 
may apply to the Minister for a certificate of nationality stating that the applicant is an Irish citizen. ${ }^{51}$

\section{Recent developments related to the acquisition of citizenship by birth}

The acquisition of citizenship by children born in Ireland to non-national parents who have not had three years of 'reckonable' residence in the State, and by children born to undocumented parents has gained renewed attention in recent years. In particular, the issue received much attention following the making of a deportation order against a woman with undocumented status and her nine-year old son who had been born in Ireland. The deportation order was subsequently revoked following campaigns by the public (O'Brien, 2018). Commentators have recently criticised the referendum on the $27^{\text {th }}$ amendment to the Constitution, which removed birthright citizenship from the Constitution in 2004 (O'Toole, 2019). While some commentators critical of the referendum have called for the $27^{\text {th }}$ amendment to be repealed (Fitzgerald, 2018; O'Toole, 2019), Thornton (2018a; 2018b) states that the acquisition of citizenship by minors born in the State to undocumented parents can be addressed by way of legislation, rather than a Constitutional amendment.

Recent efforts have been made by legislators to address the situation of children born in Ireland to non-national parents. The Irish Nationality and Citizenship (Restoration of Birthright Citizenship) Bill 2017, which aimed to restore Irish-born children's right to citizenship, was defeated in early $2019 .{ }^{52}$ The then Minister cited the EU-wide stance against unconditional birthright citizenship as well as the implications of the proposed legislation on acquisition of EU citizenship rights as reasons for his opposition to the legislation. ${ }^{53}$ The Minister stated:

From a European Union point of view, we would be granting not just Irish citizenship but also EU citizenship, and not just to children but, inevitably, to a much wider cohort of people. ${ }^{54}$

It was also stated that:

This would create a major incentive for non-EEA nationals in other EU member states, particularly those there illegally and without lawful authority and those with non-reckonable residency, to come here to have

51 Irish Nationality and Citizenship Act 1956 (as amended), s 28(1). See also Berkeley Solicitors, 'Stateless child born in Ireland granted a certificate of nationality', 28 August 2020, https://berkeleysolicitors.ie/stateless-child-born-inireland-granted-a-certificate-of-nationality.

52 Irish Nationality and Citizenship (Restoration of Birthright Citizenship) Dáil Bill (2017) 36, available at www.oireachtas.ie/en/bills/bill/2017/36.

53 Houses of the Oireachtas, 'Irish Nationality and Citizenship (Restoration of Birthright Citizenship) Bill 2017: Second Stage', Dáil Éireann debate, Vol. 977, No. 6, 17 January 2019, www.oireachtas.ie/en/debates/debate/dail/2019-0117/53.

54 Ibid. 
their child. Such persons could in turn return to the original EU member state as soon as the child is born having secured Irish citizenship, thereby circumventing the immigration laws of any EU member state. ${ }^{55}$

The Minister's arguments echo those put forward by the then Minister for Justice, Equality and Law Reform who argued for the removal of jus soli citizenship in 2004.56

In November 2018, the Irish Nationality and Citizenship (Naturalisation of Minors Born in Ireland) Bill 2018 was tabled in the Seanad. ${ }^{57}$ The 2018 Bill provided that children born in Ireland whose parents are not legally resident, or do not have reckonable residence, would be eligible to apply for naturalisation after three years residence in Ireland, regardless of their parents' legal status. ${ }^{58} \mathrm{~A}$ similar argument to that which was proposed in relation to the Irish Nationality and Citizenship (Restoration of Birthright Citizenship) Bill 2017 was put forward against the Bill by the government. ${ }^{59}$ The Bill had reached the third (or committee) stage in the Seanad, before lapsing with the dissolution of the Dáil and Seanad in light of the general election held in February 2020. ${ }^{60}$ Following the general election, this Bill was restored to the Order Paper at Committee Stage.

In September 2020, the Irish Nationality and Citizenship (Citizenship for Children) Bill 2020 was introduced in Dáil Éireann. ${ }^{61}$ The Bill seeks to restore the eligibility for citizenship of all persons born in the island of Ireland and to extend and enhance eligibility for citizenship of children resident in Ireland for a certain period of time. In particular, the Bill proposes that children resident in Ireland for a total period of three years while a child is entitled to be an Irish citizen. ${ }^{62}$

56 In the course of parliamentary debates prior to the 2004 referendum, the then Minister stated that the judgement by the Court of Justice of the European Union in Chen v UK [2004] ECR I-9925 'upheld the right of Mrs. Chen to deliberately engineer a situation in which her child would acquire Irish citizenship through birth in Northern Ireland in order to secure long-term residence for both herself and her child in the United Kingdom' in arguing for the removal of unconditional jus soli citizenship in Ireland. See: Dáil Éireann, 'Irish Nationality and Citizenship Bill 2004', 9 November 2004, www.oireachtas.ie/en/debates/debate/dail/2004-11-09/18. Irish Nationality and Citizenship (Naturalisation of Minors Born in Ireland) Seanad Bill (2018) 124, available at www.oireachtas.ie/en/bills/bill/2018/124.

58 Houses of the Oireachtas, 'Irish Nationality and Citizenship (Naturalisation of Minors Born in Ireland) Bill 2018: Second Stage', Seanad Éireann debate, Vol. 261, No. 7, 21 November 2018, www.oireachtas.ie/en/debates/debate/seanad/2018-11-21/21. Ibid.

60 Irish Nationality and Citizenship (Naturalisation of Minors Born in Ireland), Seanad Bill 124 of 2018 , www.oireachtas.ie/en/bills/bill/2018/124.

61 Irish Nationality and Citizenship (Citizenship for Children) Dáil Bill (2020) 33, available at www.oireachtas.ie/en/bills/bill/2020/33. Ibid. 


\subsubsection{Naturalisation}

The acquisition of citizenship through naturalisation is the primary pathway to citizenship for migrants who are resident in Ireland and who have no prior ties to Ireland.

Citizenship through naturalisation is granted at the discretion of the Minister for Justice and Equality (the Minister) and is subject to the applicant satisfying certain conditions, including residence for a period of five years in Ireland. ${ }^{63}$ The conditions for naturalisation and the naturalisation procedure are set out in further detail in Chapters 4 and 5. Certain naturalisation requirements may be waived at the discretion of the Minister for certain naturalisation applicants, including applicants of 'Irish descent or associations', children whose parent naturalises, applicants who are, or have been, resident abroad in the public service, and refugees and stateless persons. ${ }^{64}$

Specific naturalisation conditions apply to spouses and civil partners of Irish citizens. ${ }^{65}$ Under now repealed provisions of the 1956 Act, a non-Irish national who married an Irish citizen prior to 30 November 2002 could make a post-nuptial declaration to acquire Irish citizenship after three years of marriage. The postnuptial declaration process was repealed with effect from 30 November 2002 (Department of Justice, Equality and Law Reform, 2003). A transition provision allowed individuals who had married an Irish citizen before 30 November 2002, but had not satisfied the three-year requirement by 30 November 2002, to make a declaration of post-nuptial citizenship on reaching three years' marriage by 30 November 2005 (Department of Justice, Equality and Law Reform, 2006a). Non-national spouses and civil partners of Irish citizens must now apply for naturalisation in order to acquire Irish citizenship.

As the government has acknowledged, however, in previous policy statements on integration, naturalisation may not be an option for some persons residing in Ireland, as some countries require citizens to renounce their citizenship before acquiring the citizenship of another country (Department of Justice, Equality and Law Reform, 1999). Where applying for naturalisation is not an option, non-EU nationals resident in Ireland may be able to apply for permission to remain 'without condition as to time' or long-term residence. Long-term residence status is available on the basis of an administrative scheme, ${ }^{66}$ and is open to non-EU national employment permit holders (and their dependent spouses) and scientific

$63 \quad$ Irish Nationality and Citizenship Act 1956 (as amended), s 15.

64 Irish Nationality and Citizenship Act 1956 (as amended), s 16.

65 Irish Nationality and Citizenship Act 1956 (as amended), s $15 \mathrm{~A}$.

66 Ireland has not opted into EU Directives 2003/109/EC and 2011/51/EU concerning long-term residence, which establish minimum standards on the granting of long-term residence status to non-EU nationals in EU Member States. 
researchers, after a minimum of five years' residence in the State. ${ }^{67,68}$ People that have resided in Ireland for at least eight years on the basis of an eligible residence permission may alternatively apply for permission to remain in Ireland 'without condition as to time'. ${ }^{69}$ However, several categories of migrants residing in the State are excluded under both schemes (EMN, 2020c; Cosgrave, 2011).

As these schemes are limited in scope to certain categories of residence permission, citizenship by naturalisation may be viewed as the primary route for many migrants to secure their residence on a permanent basis in Ireland. This is particularly the case for non-EU nationals, who do not have the freedom enjoyed by EU nationals to live and work in Ireland without restriction.

\subsubsection{Other modes of acquiring Irish citizenship}

\section{Acquisition of citizenship by foundlings (deserted new-born children)}

Every deserted new-born child first found in the State is deemed to have been born in the island of Ireland to parents at least one of whom is an Irish citizen, unless proven to the contrary, and thus is deemed to be an Irish citizen from birth. ${ }^{70}$

\section{Acquisition of citizenship by adopted children}

A child adopted on the basis of an adoption order made by an Irish citizen is an Irish citizen. ${ }^{71}$

\section{Irish citizenship granted as a token of honour}

Irish citizenship may be granted as a token of honour by the President to a person, or child or grandchild of a person who 'in the opinion of the Government has done signal honour or rendered distinguished service to the nation'. ${ }^{72}$ A certificate of Irish citizenship is issued to the person granted citizenship as a token of honour. ${ }^{73}$

67 INIS, 'Long Term Residency', http://www.inis.gov.ie/en/INIS/Pages/Long_Term_Residency.

68 The Migrant Integration Strategy 2017-2020 committed to introducing a statutory scheme for long-term residence. However, the recommendation made in the strategy's mid-term progress report was to opt for an administrative scheme (Department of Justice and Equality, 2019). Department of Justice and Equality, 'Without Condition As To Time Endorsements', www.inis.gov.ie/en/inis/pages/without_condition_as_to_time_endorsements. Irish Nationality and Citizenship Act 1956 (as amended), s 10. Irish Nationality and Citizenship Act 1956 (as amended), s 11. Irish Nationality and Citizenship Act 1956 (as amended), s 12(1). Irish Nationality and Citizenship Act 1956 (as amended), s 12(2). 


\section{Acquisition of citizenship through naturalisation}

The Irish Nationality and Citizenship Act 1956 (as amended) (the 1956 Act) governs the acquisition of citizenship, including through naturalisation. Section 15 of the 1956 Act sets out the conditions for naturalisation. To acquire citizenship through naturalisation an individual must apply to the Minister for Justice and Equality (the Minister) for a certificate of naturalisation. Additional application requirements have been introduced by way of statutory instruments made under the 1956 Act as well as on an administrative, non-statutory, basis.

Specific conditions apply to naturalisation of spouses or civil partners of Irish citizens. Certain categories of non-Irish nationals may also have certain naturalisation conditions waived to facilitate the acquisition of citizenship, including minor children of naturalised Irish citizens, people of Irish descent or associations, and people recognised as refugees and stateless persons.

This chapter examines the conditions that apply to an individual who makes an application for naturalisation in Ireland. It also presents data on naturalisation trends in Ireland, including applications received, and certificates issued, by the Department of Justice and Equality (the Department) in recent years.

\subsection{CONDITIONS FOR THE ACQUISITION OF CITIZENSHIP THROUGH NATURALISATION}

Section 15 of the 1956 Act, as amended (the 1956 Act), sets out conditions that an applicant must satisfy for naturalisation. The Minister may in his absolute discretion grant the application if he is satisfied that the applicant:

- is of full age, or is a minor born in the State;

- is of good character;

- has had a period of one year's continuous residence in the State immediately before the date of the application and, during the eight years immediately preceding that period, has had a total residence in the State amounting to four years;

- intends in good faith to continue to reside in the State after naturalisation; and

- has, before a judge of the District Court in open court, in a citizenship ceremony or in such manner as the Minister, for special reasons, allows, made a declaration, in the prescribed manner, of fidelity to the nation and loyalty to 
the State, and undertaken to faithfully observe the laws of the State and to respect its democratic values. ${ }^{74}$

The Minister has absolute discretion when considering naturalisation applications. ${ }^{75}$ The naturalisation procedure in Ireland is privilege-based rather than rights-based, with naturalisation often referred to as 'a privilege and honour' rather than a right or entitlement. ${ }^{76}$

The absolute discretion afforded to the Minister has been criticised by NGOs and commentators for a lack of transparency in decision-making (Handoll, 2012; Cosgrave, 2011). Findings from the MIPEX project state that while Ireland has relatively favourable eligibility rules for citizenship, Ireland has one of the most discretionary citizenship policies among 38 countries (Huddleston et al., 2015). ${ }^{77}$

\subsubsection{Age condition}

An applicant must be 18 years of age, ${ }^{78}$ or a child born in Ireland, ${ }^{79}$ to be eligible for naturalisation. A child born in Ireland, but who is not entitled to citizenship at the time of birth, ${ }^{80}$ is eligible to apply for naturalisation after five years' 'reckonable residence' in Ireland. When the 1956 Act was adopted, section 15 of the 1956 Act provided that the applicant must be of full age to be eligible for naturalisation. The Irish Nationality and Citizenship Act 2004 amended the 1956 Act to include children born in Ireland among the eligibility conditions for naturalisation. ${ }^{81}$

Children who were not born in Ireland are eligible to apply for citizenship through naturalisation if they are of 'Irish descent or associations' (see Section 4.2.1), ${ }^{82}$ or if their parent has been granted citizenship through naturalisation (see Section 4.2.2) ${ }^{83}$ In practice, the residence requirement is reduced to three years in these cases. Children who migrated to Ireland as a child and do not fall within these two categories must wait until they are 18 years old to apply for citizenship

Irish Nationality and Citizenship Act 1956 (as amended), s 15.

Ibid.

Parliamentary Question [23123/19], 30 May 2019, available at www.oireachtas.ie; Immigration Service Delivery, 'Form 8: Application by a person of full Age for naturalisation as an Irish citizen', www.irishimmigration.ie/wpcontent/uploads/2019/11/form-CTZ3.pdf.

MIPEX is a project that measures integration policies in 38 countries including all EU Member States, Australia, Canada, Iceland, Japan, New Zealand, Norway, South Korea, Switzerland, Turkey, the United Kingdom and the United States.

Irish Nationality and Citizenship Act 1956 (as amended), s 15(1)(a)(i).

Irish Nationality and Citizenship Act 1956 (as amended), s 15(1)(a)(ii).

Section 6A of the Irish Nationality and Citizenship Act 1956 (as amended) provides that children born in Ireland to non-Irish parents who have legally resided in Ireland for three out of the four years immediately prior to the child's birth is entitled to Irish citizenship, provided the residence was reckonable.

Irish Nationality and Citizenship Act 2004, s 8.

Irish Nationality and Citizenship Act 1956 (as amended), s 16(1)(b); Immigration Service Delivery, 'Form 10: Application for a Certificate of Naturalisation by a Parent or Guardian acting on behalf of a minor of Irish decent or Irish Associations', www.irishimmigration.ie/wp-content/uploads/2019/11/form-CTZ5.pdf.

Irish Nationality and Citizenship Act 1956 (as amended), s 16(1)(c). 
independently and an application may not be made on their behalf. The Immigration Council of Ireland notes how these provisions can delay access to citizenship for children (Mannion, 2016). The Migration Policy Group and Immigrant Council of Ireland (2013) observed this approach has an adverse impact on access to funding for third-level education in particular and that many young people are required to pay non-EU rates for third-level education even though they have been living in the country for a significant part of their lives.

In cases where a child wishes to apply for naturalisation, the child is not permitted to make the application for naturalisation by themselves. An application for naturalisation by a child must be made by the child's parent, legal guardian or a person acting in loco parentis to the child. ${ }^{84,85}$

The question as to who is the applicant in cases where children apply for naturalisation has arisen in case law in Ireland. In Iurescu $v$ Minister for Justice and Equality, Ireland and the Attorney General, ${ }^{86}$ the High Court held that while the applicant for the purposes of the making of an application for naturalisation by a child is the parent, guardian or person acting in loco parentis, the applicant that must satisfy the conditions for naturalisation is the child. Nevertheless, some of the information requested in the application on behalf of a child born in Ireland (Form 11) tends to reflect the interpretation that it is the parent, guardian or person acting in loco parentis who must satisfy the conditions for naturalisation (see for example Section 4.1.2 on the good character requirement). ${ }^{87}$

The Immigrant Council of Ireland has highlighted that the provisions of the 1956 Act do not respect children's evolving autonomy and can prevent access to citizenship where the parent or guardian is not available or willing to submit an application for the child (Mannion, 2016). In particular, the Immigrant Council of Ireland stated that it is unclear whether an application for naturalisation can be made by a social worker acting as the guardian of a child in the care of the State. The Immigrant Council of Ireland notes that the Minister does not accept applications made on behalf of children in care under a full care order, ${ }^{88}$ where the application is signed by the child's social worker, as it is the Minister's position that minor born in the State who did not at birth have an entitlement to Irish citizenship under Section 6A of the Act of 1956', www.irishimmigration.ie/wp-content/uploads/2019/11/form-CTZ6.pdf.

86 [2019] IEHC 535.

[2019] IEHC 535 [30].

88 The power to make an application for naturalisation is not among the powers given to the Child and Family Agency in respect of a child in care under a full care order pursuant to Section 18 of the Child Care Act 1991 (as amended). 
a social worker is not a legal guardian for the purpose of such applications. ${ }^{89}$ In respect of migrant children subject to a full care order, the Immigrant Council of Ireland recommended that consideration be given to amending section 18(3) of the Child Care Act 1991 (as amended) to provide the Child and Family Agency with the authority to make naturalisation applications on behalf of minors in care. ${ }^{90} \mathrm{It}$ has further recommended that the 1956 Act be amended to allow children make applications for naturalisation independently on meeting specific criteria and on completion of prescribed lengths of residence (Mannion, 2016). The Immigrant Council of Ireland also indicated that it is unclear whether time spent in the care of the State can be considered reckonable for the purpose of naturalisation regardless of a parent's residence status. It recommended that the time children spend in care be deemed reckonable for naturalisation, regardless of whether a parent held a legal residence permission during that time (ibid.).

\section{Age condition in EU Member States}

In most Member States, children under 18 cannot apply for citizenship on their own accord and acquisition is typically linked to the naturalisation of their parent(s). Certain Member States provide that a child can automatically acquire citizenship on the naturalisation of their parent(s). In France and Greece, citizenship law provides that children will automatically acquire citizenship on the naturalisation of their parent(s), provided the child is a minor and unmarried (EMN France, 2019; EMN Greece, 2019). Children under the age of 18 are granted citizenship on the acquisition of Belgian citizenship by their parent(s), provided their primary residence is in Belgium. ${ }^{91}$ Citizenship law in Luxembourg provides that a minor child whose parent obtains Luxembourg citizenship will become a citizen of Luxembourg (EMN Luxembourg, 2019). A grant of citizenship to an adult in Poland will also apply to children in that person's custody, with the consent of such children being required from the age of 16 (Górny and Pudzianowska, 2013; EMN Poland, 2019). Italian citizenship law provides that minor children of a person who acquires Italian citizenship shall acquire such citizenship where they live with that person (EMN Italy, 2019). Swedish citizenship law provides that in a decision concerning naturalisation of an adult, consideration will be given to whether the applicant's unmarried child under the age of 18 shall acquire Swedish citizenship (Bernitz, 2013).

In the UK, children cannot naturalise; however they can acquire citizenship through other means, including registration. A child born in the UK to a non-UK national who subsequently becomes settled, or children who are born in the UK and live in

89 Submission by the Immigrant Council of Ireland to the Department of Children and Youth Affairs written consultation on the review of the Child Care Act 1991, 23 February 2018, available at www.gov.ie/en/publication/ee2a23submissions-to-the-written-consultation-on-the-review-of-the-child-c. Ibid.

91 Code of Belgian Nationality, 28 June 1984, Belgian Official Gazette, available at www.ejustice.just.fgov.be/cgi_loi/change_lg.pl?language=fr\&la=F\&table_name=loi\&cn=1984062835, Article 12. 
the UK until they are ten years old, may acquire citizenship through registration. In addition, where one or both parents are applying for British citizenship, they may apply for their child who is not automatically British at birth to be registered as citizens as part of a family application at the discretion of the Minister (Home Office, 2019). However, Sawyer and Wray (2014) note access to registration can be difficult to exercise in practice, with high costs for a registration application and lack of awareness of the need to ensure registration occurs when the child is still a minor.

However, some EU Member States provide for the naturalisation of children independently of their parent's naturalisation process (Mannion, 2016). For example, in Sweden, children can acquire citizenship on notification, made on their behalf by their guardian, if the child holds a permanent residence permit and has resided in Sweden for three years. ${ }^{92}$ Prior to 2015, children were required to have five years residence, however the residence required was reduced in order to minimise the instances in which children have widely varying prospects of acquiring citizenship, depending on whether or not the child is born at a time when their parents met the necessary conditions for the child to automatically acquire citizenship at birth (Medborgarskapsutredningen, 2013). In Slovakia, children under 18 that were born or resident in Slovakia are eligible to apply for citizenship, with the eight-year permanent residence requirement reduced to three years (EMN Slovakia, 2019).

Some EU Member States also make express provision for children in care to acquire citizenship (see also Mannion, 2016). Citizenship law in the Czech Republic provides that a child who resides in institutional, foster or other forms of alternative care may acquire citizenship by declaration and an application may be made by the child's legal representative, guardian, or carer, with applications on behalf of children over the age of 15 requiring the child's consent (EMN Czech Republic, 2019). ${ }^{93}$ Similarly, in Slovakia, a child whose legal representative or guardian is a Slovak citizen or a legal entity appointed by a court may apply for citizenship, with the eight-year residence requirement reduced to two years for children over two years of age and waived for children under two years of age (EMN Slovakia, 2019). Children under the age of 15 and assigned a guardian in Estonia may have an application made on their behalf by their guardian, provided the child resides permanently in Estonia (EMN Estonia, 2019). In Portugal, at the request of the Public Prosecutor's Office, children under the age of 18 and cared for by a public, cooperative, social or private institution with a cooperation the Czech Republic), §36, available at

www.mzv.cz/file/2400342/Citizenship_Act_No._186_2013_Sb._o_statnim_obcanstvi_CR.pdf. 
agreement with the State, may apply for naturalisation (Gil and Piçarra, 2020). Children who are in the guardianship, custody or care of a Spanish citizen or institution for two consecutive years may apply for citizenship, with the general ten-year residence requirement reduced to one year for such children (EMN Spain, 2019).

\subsubsection{Good character condition}

The 1956 Act states the Minister must be satisfied the applicant is of 'good character'. ${ }^{94}$ Good character is not defined in the 1956 Act. Commentators note that what constitutes 'good character' is unclear and there is no guidance provided in this regard (Becker and Cosgrave, 2013; Otukoya, 2018).

Revisions to the naturalisation application form in 2011 sought to address the ambiguity by including clearer requirements on the information an applicant must provide in their application form relating to the good character assessment (McGinnity et al., 2012). In the naturalisation application form, applicants must supply details of all convictions in the State or any other country, as well as any civil judgments made against them. Applicants must indicate if they have been the subject of a Garda investigation in Ireland, including where they were not charged with any offence. Applicants must also indicate: if they have been, or were suspected to be, involved in war crimes, crimes against humanity or genocide; if they were associated with, have been a member of, or given support to, a terrorist organisation; or been involved in, supported, or encouraged, terrorist activities. Failure to disclose material information will adversely affect the application and may also affect future applications for up to ten years. ${ }^{95}$

The Department obtains reports from An Garda Síochána and may obtain reports from other government departments and agencies in assessing the good character of the applicant. ${ }^{96}$ All applicants aged 16 years and older are subject to a criminal records check carried out by the National Vetting Bureau of An Garda Síochána. ${ }^{97}$ An applicant's good character is also assessed through clearance by police in the applicant's home country and adherence to laws and regulations in Ireland, including regarding revenue and social welfare matters. ${ }^{98}$ It is expected that evidence of tax compliance will become mandatory as part of the assessment in

94 Irish Nationality and Citizenship Act 1956 (as amended), s 15(1)(b).

95 Immigration Service Delivery, 'Form 8: Application by a person of full Age for naturalisation as an Irish citizen', www.irishimmigration.ie/wp-content/uploads/2019/11/form-CTZ3.pdf.

$96 \quad$ lbid.

97 Parliamentary Question [6986/20], 20 May 2020, available at www.oireachtas.ie/en/debates/question/2020-0520/506.

$98 \quad$ Ibid. 
future. ${ }^{99}$ On occasion, applicants are requested to attend for an interview with officials of the Department of Justice and Equality as part of the assessment. ${ }^{100}$

Research conducted by the Immigrant Council of Ireland highlighted that the application of the good character requirement gives rise to uncertainty for naturalisation applicants and concerns among applicants and their legal representatives regarding transparency and proportionality in the decision-making process (Cosgrave, 2011). Despite not being a statutory requirement, the Minister is also reported to have frequently exercised his discretion in refusing an application on grounds of long-term dependence on the social welfare system (Cosgrave, 2011; Handoll, 2012) (see Section 4.1.6). The Immigrant Council of Ireland suggested that a clear statutory definition of good character should be provided (Cosgrave, 2011). The Immigrant Council of Ireland also recommended that the good character requirement should be deemed to be fulfilled by applicants except in circumstances where they have been charged and convicted of a serious criminal offence or in circumstances where imperative grounds of public security mean an individual should not be deemed to have good character (Cosgrave, 2011). The Immigrant Council of Ireland highlights the lack of a statutory right to appeal of a refusal, including where negative findings have been made in respect of an applicant's character (Cosgrave, 2011) (see Section 5.3).

Some guidance on the interpretation of the good character requirement has been provided by the courts. In $A B v$ Minister for Justice, Equality and Law Reform, ${ }^{101}$ the High Court held that it is for the Minister to determine what criteria to consider when assessing whether the good character requirement has been met. ${ }^{102}$ In Hussain $v$ Minister for Justice and Equality, ${ }^{103}$ the High Court noted that the Minister's assessment of good character is nonetheless amenable to judicial review and that the Minister's conclusion had to be one which was bona fide held and factually sustainable and not unreasonable. The Court noted that there was no settled or fixed interpretation of the words 'good character' but that, interpreted in the statutory context, they meant that the applicant's character and conduct must measure up to 'reasonable standards of civic responsibility as gauged by reference to contemporary values'. ${ }^{104}$ The courts have observed that the Minister cannot demand an applicant meets an 'exalted standard of behaviour that would not realistically be expected of his Irish counterparts'. ${ }^{105}$

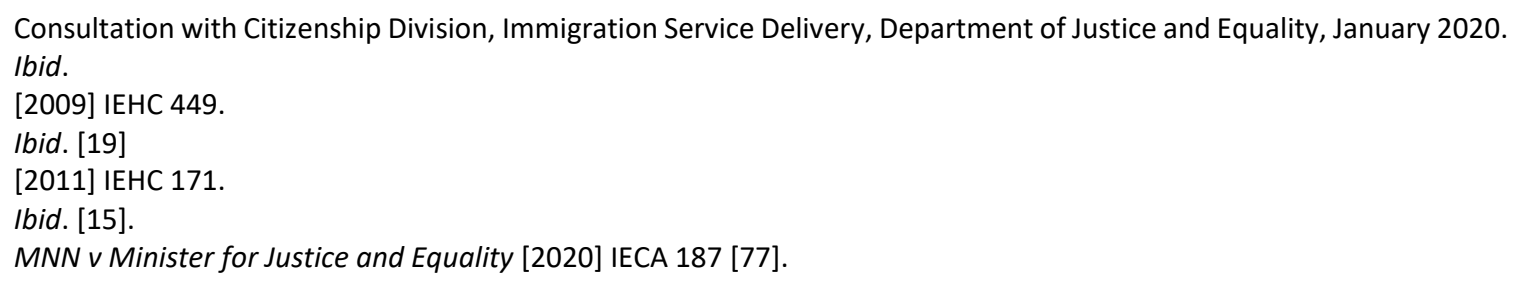


The Court of Appeal in $A A v$ Minister for Justice and Equality ${ }^{106}$ quashed a decision of the Minister to refuse citizenship to an applicant who had in the past successfully sought judicial review of a decision made on appeal of a negative asylum application decision and subsequently withdrew the appeal following her marriage to a naturalised refugee. The Court held that the Minister's refusal on a finding of absence of good character was unreasonable as it was based on conclusions drawn from the negative asylum decision occurring several years earlier and was made without consideration of the information surrounding the asylum application and the facts before the Minister. A negative decision issued by the Minister to an applicant who had been recorded as a witness in An Garda Síochána investigation was also recently struck down by the High Court. ${ }^{107}$

A number of judgments before the Irish courts have involved the interpretation of the good character requirement in relation to criminal offences, including in cases where applicants fail to disclose them. The Criminal Justice (Spent Convictions and Certain Disclosures) Act 2016, which provides that persons are generally not required to disclose a 'spent conviction', does not apply to people applying for Irish citizenship. ${ }^{108}$ Citizenship applicants must disclose all previous convictions, even if they are considered 'spent convictions'. In the past, the Minister stated that while each case is considered on its individual merits, normally a very minor motoring offence of itself would not lead to a refusal on character grounds. ${ }^{109}$ In relation to more serious motoring offences, the Minister has stated that the longer the period of time during which no further offences have occurred, the better the prospects of a positive decision in an application. ${ }^{110}$

The High Court in Hussain $v$ Minister for Justice and Equality, ${ }^{111}$ held that the Minister would be entitled to refuse an application if it could be reasonably concluded the applicant was involved in serious criminal wrong-doing, even in circumstances where the applicant was not convicted or charged with an offence. However, the court held that an applicant cannot be refused citizenship merely because they have come to adverse Garda attention. ${ }^{112}$

[2019] IECA 272.

I v Minister for Justice and Equality [2019] IEHC 515.

Criminal Justice (Spent Convictions and Certain Disclosures) Act 2016, s 8(1). Section 5 of the Criminal Justice (Spent Convictions and Certain Disclosures) Act 2016 provides that certain convictions are regarded as a spent conviction where inter alia seven years have passed since the conviction and the person has served or complied with any sentence or court order in respect of the conviction.

Parliamentary Question [39571/12], 19 September 2012, available at www.oireachtas.ie/en/debates/question/201209-19/168.

Ibid.

[2011] IEHC 171.

Hussain [22]-[23]. 
In GKN v Minister for Justice and Equality ${ }^{113}$ the Court quashed the Minister's decision to refuse to grant citizenship to the applicant, who was deemed to have come to the 'adverse attention' of An Garda Síochána. The applicant had a conviction for hitting a parked, unoccupied vehicle and leaving the scene of the accident under the Road Traffic Act 1961, in respect of which the applicant had paid a fine of $€ 300$. The High Court held that, in order to conduct a proper assessment of an application and information on offences committed by an applicant, regard should be had to the outline facts of the offence, any mitigating factors, the maximum punishment and punishment imposed, as the latter would likely indicate the gravity of the offending behaviour in the eyes of the sentencing courts. ${ }^{114}$ The court also held that if an applicant makes representations to the Minister in connection with an offence or an instance in which the applicant came to the adverse attention of An Garda Síochána that may tend to excuse the applicant's behaviour, the officials should weigh that in the balance in accordance with fair procedures and bring it to the attention of the Minister. ${ }^{115}$

The Court of Appeal adopted the same principles in Talla v Minister for Justice and Equality, ${ }^{116}$ holding that, while it is open to the Minister to determine that a person is not of good character by reason of commission of offences under the Road Traffic Acts, it is the nature of those offences and the circumstances in which they were committed that will demand more attention. ${ }^{117}$ The Talla case concerned a man whose application for naturalisation was refused on the basis that he was not of good character due to having previously committed road traffic offences in the State. The Court of Appeal quashed the decision of the Minister, as the Minister had failed to express the rationale for deciding the nature of the offences committed meant the applicant was not a person of good character. In this case, the court was not satisfied the Minister had considered and weighed all relevant considerations, including submissions made by and on behalf of the applicant, before refusing the application. The Court held that the Minister must undertake a comprehensive assessment of each applicant's character as an individual and, while criminal convictions or the commission of offences are relevant to this assessment, it is wider in scope than that; and the outline facts and any mitigating circumstances, the period of time that has elapsed since the last conviction, and other factors that may be relevant to character, must all be taken into consideration. ${ }^{118}$

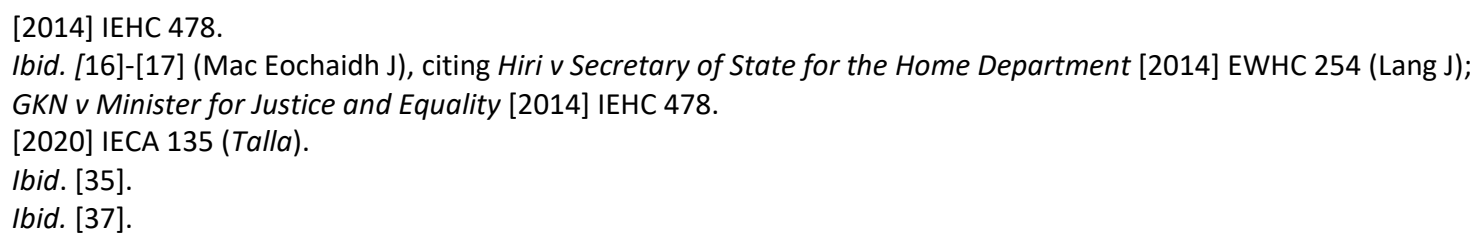


The Court of Appeal in MNN v Minister for Justice and Equality ${ }^{119}$ subsequently summarised the principles relating to the good character requirement, in a case where the court was not satisfied the Minister had considered all relevant information relating to road traffic offences and a domestic dispute in which the applicant was allegedly involved. The Court of Appeal stated that the connection between character and criminality can only be established when the Minister has all relevant information in relation to a crime, including the context and mitigating factors. The information presented in a submission or recommendation to the Minister must be accurately recorded, complete and seen in context, and considered in full by the decision-maker. The Court also held that the Minister must undertake a comprehensive assessment of an applicant as an individual and consider all aspects of character.

The courts have held that the character of adult members of an applicant's family is an irrelevant consideration in assessing the good character of the applicant. In LGH v Minister for Justice, Equality and Law Reform, ${ }^{120}$ the High Court quashed the decision of the Minister to refuse the applicant citizenship, as the Court inferred from the Ministerial examination of the applicant's file that she had been denied naturalisation because her sons had criminal convictions, which the Court viewed as irrelevant considerations. However, the High Court stated that this position may differ where an applicant's children are under the age of 18 and could reasonably be expected to be under the control and significant influence of a parent. ${ }^{121}$

The courts have also held that the good character of a child's parent is not a condition of a minor's application for naturalisation. In Iurescu (a minor) v Minister for Justice and Equality, the High Court quashed the Minister's decision to refuse a child citizenship, as it held the Minister had erred in law in concluding that it was a condition of the naturalisation of the child that the father satisfy the good character requirement. ${ }^{122}$ The Minister had refused the application as he was not satisfied the father was of good character, as the father had come to the attention of An Garda Síochána in relation to a barring order, various motoring offences, intoxication in a public place and assault causing harm. The court held that the correct interpretation of the 1956 Act is that, while the child's parent, guardian or person acting in loco parentis of the child is considered the applicant for procedural purposes, the applicant who must meet the conditions of naturalisation is the child (see also Arnold, 2020). ${ }^{123}$ 
Children aged 16 years old and over are vetted by the National Vetting Bureau. The application forms (Forms 9, 10 and 11) for submission on behalf of child applicants include a section in which the parent, guardian or person acting in loco parentis to the child must consent to vetting for children aged 16 years and above, and provide information that the Minister should be aware of in forming a judgement as to the good character of the child. Currently, applications made on behalf of children who were born in Ireland but are not entitled to citizenship by birth (Form 11) additionally require the parent, guardian or person acting in loco parentis to the child to provide information relating to the parent's/guardian's/person acting in loco parentis' own background, including information on any offences, convictions, civil judgments, criminal charges, investigations by An Garda Síochána, etc. ${ }^{124}$ The same background information relating to good character is not required in respect of the child.

\section{Good conduct requirement in EU Member States}

Applicants for naturalisation in other EU Member States must also satisfy requirements relating to good conduct (EMN, 2020a). In some Member States and the UK citizenship law provides for a general good conduct or character requirement to be met, or a requirement that applicants must not pose a threat to public order or security. ${ }^{125}$ For example, like in Ireland, applicants for UK citizenship must be 'of good character'. ${ }^{126}$ Applicants in the UK must respond to questions relating to criminal convictions, civil judgments or penalties, and involvement in war crimes, genocide, crimes against humanity and terrorism, similar to those asked of naturalisation applicants in Ireland. While not defined in UK citizenship law, guidance for Home Office staff on the assessment of the good character requirement is publicly available. ${ }^{127}$

In the majority of Member States the law specifically states that applicants must respect the laws of the State and/or applicants must not have committed certain criminal offences. ${ }^{128}$ Citizenship law in some Member States sets out the circumstances in which a criminal offence may form the basis for a refusal of citizenship. For example, in Portugal citizenship law states that an applicant must not have been convicted with a final sentence of imprisonment equal to or greater than three years. ${ }^{129}$ In Luxembourg an applicant may be refused citizenship if they have been convicted in Luxembourg or abroad with a criminal sentence or

Immigration Service Delivery, 'Form 11: Application by a parent or guardian of, or person who is in loco parentis to a minor born in the State who did not at birth have an entitlement to Irish citizenship under Section 6A of the Act of 1956', www.irishimmigration.ie/wp-content/uploads/2019/11/form-CTZ6.pdf. 
custodial sentence of 12 months or more, or a suspended sentence of at least 24 months, and the facts underlying a foreign conviction must also constitute a criminal offence under Luxembourg law (EMN Luxembourg, 2019). Citizenship law in Estonia states that an applicant can be refused citizenship if they have committed a criminal offence for which they were sentenced to imprisonment for more than one year, and whose conviction has not been spent, or if they have been repeatedly convicted of intentionally committed criminal offences. However, a discretionary exemption provides that Estonian citizenship may be granted to a person who has been repeatedly convicted of intentionally committed criminal offences and whose convictions have been spent, depending on the circumstances relating to the commission of the criminal offences and the personality of the offender (EMN Estonia, 2019). In Belgium, citizenship law states that an application may be refused if 'serious personal facts' exist in relation to the applicant. ${ }^{130}$ Examples of these include a sentence to a term of five years imprisonment for specific offences including crimes against the King and against the security of the State, crimes against humanity, war crimes or terrorist offences, a sentence imposed on the applicant on the basis of tax or social fraud, or participation in a movement or association that is deemed a threat to State security. ${ }^{131}$

In Austria, Bulgaria, Croatia, Cyprus, Czech Republic, Greece, Italy, Luxembourg, Latvia, Lithuania, Malta, Portugal, Romania, Slovakia, Slovenia and Spain, in addition to the relevant citizenship authorities conducting background checks, the applicant must submit documentation to satisfy the relevant good conduct requirement. ${ }^{132}$ Such documentation may include a copy of their criminal record in the EU Member State and/or country of origin or country/countries of previous residence, or a statement from the relevant authorities relating to the applicant's criminal record in their country of origin.

In Member States such as Croatia, the Czech Republic, Finland, Latvia, Slovakia, Slovenia and the UK, applicants are also assessed as to whether they are tax compliant. ${ }^{133}$ These assessments may be conducted by the citizenship authorities themselves or may require submission of specific documentation by applicants. Applicants in Slovakia must submit confirmation or certification from tax authorities, the relevant local authority, and their employer on the payment of taxes and other fees and payments (EMN Slovakia, 2019). Applicants in the Czech Republic must submit certification from the relevant authorities, including tax and

Code of Belgian Nationality, 28 June 1984, Belgian Official Gazette, available at www.ejustice.just.fgov.be/cgi_loi/change_lg.pl?language=fr\&la=F\&table_name=loi\&cn=1984062835, Article $15 \S 3$. Code of Belgian Nationality, 28 June 1984, Belgian Official Gazette, available at www.ejustice.just.fgov.be/cgi_loi/change_Ig.pl?language=fr\&la=F\&table_name=loi\&cn=1984062835, Article $1 \S 2$. Information retrieved from government websites, GLOBALCIT country profiles, and templates published by EMN National Contact Points for the study Pathways to citizenship for third-country nationals in the EU, available at www.ec.europa.eu/home-affairs/what-we-do/networks/european_migration_network/reports_en.

Ibid. 
Customs authorities, social security authorities and health insurance companies, which confirm there are no outstanding payments on record for the applicant (EMN Czech Republic, 2019).

\subsubsection{Residence condition}

To apply for a certificate of naturalisation an applicant must have a total 'reckonable' residence of five years during the previous nine years, including one year of 'continuous residence' immediately prior to the date of application. ${ }^{134}$ The minimum residence required in EU Member States ranges from three to ten years, with five years being the minimum requirement in ten other EU Member States ${ }^{135}$ and the UK (Mentzelopoulou and Dumbrava, 2018; EMN, 2020a).

\section{Reckonable residence}

The five years an applicant has spent in Ireland must be deemed to be 'reckonable' residence. ${ }^{136}$ Some periods of lawful stay in Ireland are not reckonable for the purpose of naturalisation. Residence for the purpose of a course of education or study is not considered reckonable residence for the purposes of naturalisation. ${ }^{137}$

A period of residence as an international protection applicant under the Refugee Act 1996 is also not reckonable for naturalisation. ${ }^{138}$ The 1956 Act has not been amended to reflect the International Protection Act 2015, which has since repealed the Refugee Act 1996, and therefore does not address whether time spent as an international protection applicant under the International Protection Act 2015 is reckonable for naturalisation purposes. In practice however, the Minister for Justice and Equality accepts time spent in the application process by those subsequently granted refugee status as reckonable residence for naturalisation purposes, ${ }^{139}$ reflecting the declaratory nature of refugee status. The time an individual granted subsidiary protection spends in the international protection application process is not considered 'reckonable' residence for naturalisation purposes. ${ }^{140}$

Citizenship Division stated that Stamp 0 is considered reckonable residence. ${ }^{141}$ Stamp 0, which is described as a 'low level' immigration status to cover persons for a limited and specific stay in Ireland and who are required to be self-sufficient, was previously deemed not reckonable for the purposes of citizenship. Practitioners

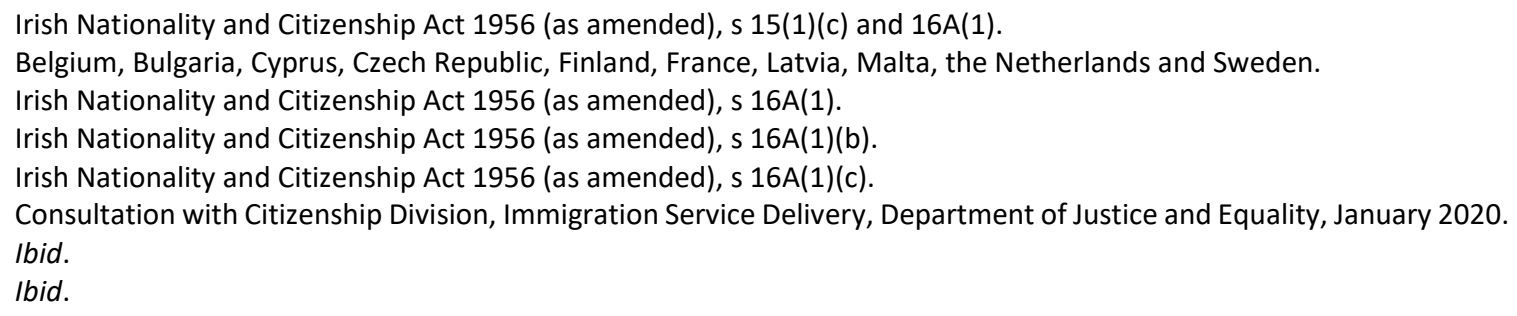


welcomed the granting of citizenship to individuals who have resided in Ireland on the basis of Stamp 0 as a positive development. ${ }^{142}$ The Naturalisation Residency Calculator does not include Stamp 0 as an option for calculating residence, ${ }^{143}$ however the Department stated that proofs of Stamp 0 in a passport can be provided as supplementary documentary evidence. ${ }^{144}$

Residence in Ireland illegally is also not reckonable for the purpose of naturalisation. ${ }^{145}$ Non-EU nationals must provide evidence of the residence permission stamps that are placed in their passport when a residence permission is granted (see Section 5.1.2). The Minister has stated that all non-EU nationals are required to keep their permission to remain in the State up-to-date at all times and to have such permission registered; failure to do so may adversely affect an application for a certificate of naturalisation. ${ }^{146}$ Any gaps between residence permissions are deemed unlawful periods of residence and thus are not counted in assessing the period of residence. Becker and Cosgrave (2013) note that this includes cases where gaps between residence permissions are caused by administrative delay through no fault of the applicant. In recent years, non-EU nationals have reported facing challenges in scheduling appointments to renew their residence permission at the Department on time using the online booking system (Pollak, 2018; Taylor, 2019). A new online registration renewal system was launched in July 2020 to facilitate non-EU nationals based in Dublin to renew their registration in the State. ${ }^{147}$ The Immigrant Council of Ireland states that problems may arise when non-EU nationals subsequently apply for citizenship and may be penalised for delays that arise in relation to registration and renewal of registration that are not the fault of the applicant. ${ }^{148}$

In Sulaimon v Minister for Justice, Equality and Law Reform, ${ }^{149}$ the Supreme Court overturned a decision by the Minister to refuse citizenship to a child on the basis of calculations of the father's residence. While the judgment dealt with birthright citizenship, the issues raised related to the calculation of residence permissions to determine 'reckonable' residence. The father of the child had sought to claim birthright citizenship on behalf of his child, on the basis that the father had resided for three years in Ireland prior to the child's birth. The father had been granted

142 Berkeley Solicitors, 'Client of Berkeley Solicitors Recently Had Their Stamp 0 Permission Accepted as Reckonable Residence for Naturalisation', 22 January 2020, https://berkeleysolicitors.ie/client-of-berkeley-solicitors-recently-hadtheir-stamp-0-permission-accepted-as-reckonable-residence-for-naturalisation. Department of Justice and Equality, 'Naturalisation Residency Calculator', www.inis.gov.ie/en/INIS/Pages/Naturalisation_Residency_Calculator. Comments received from the Department of Justice and Equality, October 2020.

Irish Nationality and Citizenship Act 1956 (as amended), s 16A(1)(a).

Parliamentary Question [18257/19], 18 April 2019, available at www.justice.ie/en/JELR/Pages/PQ-18-04-2019-141. Department of Justice and Equality, 'Minister McEntee announces expansion of online Registration Renewal system to include all Dublin-based non-nationals', Press Release, 7 July 2020, www.justice.ie/en/JELR/Pages/PR20000136. Immigrant Council of Ireland, 'Huge cracks in immigration system magnified during Covid-19', Press Release, 29 July 2020, www.immigrantcouncil.ie/news/huge-cracks-immigration-system-magnified-during-covid-19. 
permission to reside in the State by way of a letter on a date that was more than the three years required prior to the child's birth, however the residence stamps placed in his passport on registration amounted to less than three years. His application was refused on the grounds that he was three days short of three years on the day of the child's birth. The parties to the case disputed the meaning of permission and the date on which the father's permission to remain was deemed to have been granted. The Supreme Court held that the date on which the letter was sent by the Minister, informing the father that the Minister had decided to grant him permission, constituted the date from which permission to remain was granted. This was distinct from the date on which the permission was later registered and a stamp placed in the father's passport.

\section{Continuous residence}

An applicant must have, immediately before the date of the application, one year's 'continuous residence' in the State. ${ }^{150}$ In August 2016, the Department of Justice and Equality adopted a 'six-week rule' on an administrative basis, which allows applicants to be absent from the State for up to six weeks, in order to provide for absences from the State for normal holidays and other short-term and temporary absences, such as for business meetings or a family wedding or bereavement or medical emergency while abroad. ${ }^{151}$ Under this rule applicants who are absent from the State more than six weeks in the year prior to applying for naturalisation are not deemed to have met the necessary 'continuous residence' requirement. The Minister may allow some further discretion where there are wholly exceptional or unavoidable circumstances. ${ }^{152}$

The Department stated that codification of Ministerial policy regarding residence and the six-week rule was published on the Department of Justice and Equality website. ${ }^{153}$ The residence section of Immigration Service Delivery's citizenship website states that applicants must prove one year of 'continuous residence' immediately before the date they apply. Reference is not currently made to the application of the six-week rule. In the application form, applicants are requested to state if they have been absent for longer than six weeks in the five years prior to application and, if so, to provide details of all absences. ${ }^{154}$ It also states that where there are significant absences from the State, further enquiries may be necessary and the application may be refused.

Irish Nationality and Citizenship Act 1956 (as amended), s 15(1)(c).

Consultation with Citizenship Division, Immigration Service Delivery, Department of Justice and Equality, January 2020.

Ibid.

Ibid.

Immigration Service Delivery, 'Form 8: Application by a person of full Age for naturalisation as an Irish citizen', www.irishimmigration.ie/wp-content/uploads/2019/11/form-CTZ3.pdf. 
The six-week rule was defended by the Minister as 'reasonable and generous', ${ }^{155}$ while some practitioners branded the time limit as draconian and potentially unlawful (Hilliard, 2018a). Instances were reported in the media of applicants for citizenship being refused naturalisation due to absences for periods of longer than six weeks in the year prior to application. In one case, an applicant was deemed ineligible for naturalisation due to two separate holidays abroad amounting to a total of seven weeks' absence in the year prior to the application being made (Hilliard, 2018b). The Department subsequently re-examined that applicant's case and granted the applicant citizenship (Hilliard, 2018c).

The interpretation of continuous residence and the six-week rule adopted by the Department was the focus of a significant court case in 2019. In Jones v Minister for Justice and Equality, ${ }^{156}$ the applicant brought judicial review proceedings in respect of a negative decision on the applicant's naturalisation application issued by the Minister in 2018 due to absences from the State amounting to a total of 100 days. The applicant submitted that the Minister had applied the continuous residence rule in an 'overly literal manner' and failed to make any reasonable allowance for temporary absences from the State for valid reasons such as holidays, and argued that the Minister had erred in law by applying a policy that the continuous residence requirement cannot be satisfied where the applicant is absent from the State for over six weeks. ${ }^{157}$ The High Court held that the six-week rule was unlawful and that the Minister had gone beyond what was legally permissible in applying a six-week rule in interpreting the continuous residence requirement. The High Court held that continuous residence means unbroken and uninterrupted residence, thus no absence is legally allowed. ${ }^{158}$ The judgment was met with concern from NGOs and practitioners, with the Immigrant Council of Ireland stating the rule placed an illogical burden on applicants in a globalised society. ${ }^{159}$ Following the judgment, the Department stated that the Minister had received approval from Government for a proposed Bill to address the issues raised in the judgment. ${ }^{160}$ The Department stated that the Bill would be put before the Houses of the Oireachtas for consideration by mid-September 2019. ${ }^{161}$

The judgment was subsequently appealed by the applicant and was heard at the Court of Appeal on 8 October 2019. On 14 November 2019, the Court of Appeal delivered its judgment in which it held that the High Court erred in law in stating

\footnotetext{
155 Parliamentary Question [3981/18], 30 January 2018, available at www.justice.ie.

[2019] IEHC 519.

Roderick Jones v Minister for Justice and Equality [2019] IECA 285 [10].

Ibid.

Immigrant Council of Ireland, 'Citizenship Applications - Continuous Residence Requirement', 18 July 2019, www.immigrantcouncil.ie/news/citizenship-applications-continuous-residence-requirement. 
that naturalisation applicants must have unbroken residence in the year prior to their application, which the Court of Appeal stated was 'unworkable, overly literal, unduly rigid and gives rise to an absurdity'. ${ }^{162}$ The Court of Appeal stated that continuous residence does not require uninterrupted presence in the State nor impose a complete prohibition on travel outside of the State. ${ }^{163}$ The Court of Appeal also held that the Minister's policy of permitting up to six weeks' absence from the State was not rigid or inflexible as put forward by the applicant, and stated that the six-week rule was reasonable and pragmatic and 'facilitates flexibility, clarity and certainty' in establishing how the continuous residence requirement must be satisfied by naturalisation applicants. ${ }^{164}$

NGOs and practitioners welcomed the Court of Appeal judgment for overturning the ruling that applicants cannot leave the State in the year prior to application (McCárthaigh and Carolan, 2019). ${ }^{165}$ However, NGOs and practitioners have highlighted that guidance for applicants is needed from the Department in relation to the application of the six-week rule and the circumstances in which absences may be permitted, such as travel for work, health and family life. ${ }^{166}$ Practitioners suggest that the six-week rule policy and its applications should be freely accessible and easy to understand. ${ }^{167}$

While a common approach to residence requirements for the purpose of citizenship does not exist at EU level, the rules agreed at EU level on residence for the purpose of permanent residence acquired by EU nationals, and for the purpose of long-term residence status acquired by non-EU nationals are informative. EU Directive 2004/38/EC on the right of EU citizens and their family members to free movement in the EU provides that an EU citizen who has resided legally in another Member State for a continuous period of five years shall have the right to permanent residence in that Member State. ${ }^{168}$ The Directive provides that continuity of residence is not affected by specified absences ranging from six to

162 Roderick Jones v Minister for Justice and Equality [2019] IECA 285 [47].

163 Ibid.

164 Roderick Jones v Minister for Justice and Equality [2019] IECA 285 [59] and [66].

165 Immigrant Council of Ireland, 'Citizenship decision a relief for many, but we still need to reform immigration laws', Press Release, 14 November 2019, available at www.immigrantcouncil.ie/news/citizenship-decision-relief-many-westill-need-reform-immigration-laws; Berkeley Solicitors, 'Court of Appeal judgement in the Jones case', 14 November 2019, available at https://berkeleysolicitors.ie/court-of-appeal-judgment-in-the-jones-case; Sinnott Solicitors, 'Roderick Jones v Minister for Justice \& Equality Court of Appeal Judgement', 14 November 2019, https://sinnott.ie/roderick-jones-v-minister-for-justice-and-equality-court-of-appeal-judgement. Ibid.

167 Berkeley Solicitors, 'Court of Appeal judgement in the Jones case', 14 November 2019, available at https://berkeleysolicitors.ie/court-of-appeal-judgment-in-the-jones-case.

168 Directive 2004/38/EC of the European Parliament and of the Council of 29 April 2004 on the right of citizens of the Union and their family members to move and reside freely within the territory of the Member States amending Regulation (EEC) No 1612/68 and repealing Directives 64/221/EEC, 68/360/EEC, 72/194/EEC, 73/148/EEC, 75/34/EEC, 75/35/EEC, 90/364/EEC, 90/365/EEC and 93/96/EEC, Article 16(1). 
twelve months. ${ }^{169}$ While Ireland has opted into EU Directive 2004/38/EC, the provisions concerning temporary absences for the purpose of permanent residence for EU nationals are not reflected in guidance for naturalisation applicants. EU Directive 2003/109/EC on long-term residents provides that absences shorter than six consecutive months, and which do not exceed ten months in total, are not considered to interrupt the five-year continuous residence requirement. ${ }^{170}$ As stated above, Ireland has not opted into the Directive on longterm residents.

\section{Permitted absences in other EU Member States}

The length of permitted absences during the qualifying residence period in other EU Member States and the UK varies. In Belgium, absences of up to six months, with a maximum combined period of up to one year in the five-year required residence period, are permitted. ${ }^{171}$ In Finland, where applicants are required to prove five years of residence, an applicant may be absent for short periods up to no more than one month, a maximum of six periods of absence exceeding one but not exceeding two months, and up to two periods of absence exceeding two but not exceeding six months (EMN Finland, 2019). In Austria, where applicants for naturalisation must satisfy a ten-year residence requirement, applicants may be absent for up to 20 per cent (24 months) of the residence period (Stiller, 2019). In Spain, applicants must satisfy a ten-year residence requirement and can be absent for a maximum of six months (EMN Spain, 2019). In the UK, applicants are not permitted to be absent from the UK for more than 90 days in the 12 months prior to application, and should not have been outside the UK for more than 450 days in the five-year required residence period. A guide for applicants sets out how discretion may be applied in cases where absences exceed the limit. ${ }^{172}$ In Cyprus the final 12 months prior to application must be uninterrupted (Charalambidou, 2013; EMN Cyprus, 2019).

\section{The residence requirement and children}

As stated above, applicants must demonstrate reckonable residence in order to be eligible for citizenship. Only non-EU nationals aged 16 and over are required to apply for a residence permission if residing in the State for longer than 90 days and must register with the Department of Justice and Equality's Immigration Service Delivery or the Garda National Immigration Bureau (GNIB). ${ }^{173}$ Non-EU children

Ibid., Article 16(3). Article 16(3) states that Continuity of residence shall not be affected by temporary absences not exceeding a total of six months a year, or by absences of a longer duration for compulsory military service, or by one absence of a maximum of 12 consecutive months for important reasons such as pregnancy and childbirth, serious illness, study or vocational training, or a posting in another Member State or a third country. Council Directive 2003/109/EC of 25 November 2003 concerning the status of third-country nationals who are longterm residents, Article 4(3).

171 Code of Belgian Nationality, 28 June 1984, Belgian Official Gazette, available at www.ejustice.just.fgov.be/cgi_loi/change_lg.pl?language=fr\&la=F\&table_name=loi\&cn=1984062835, Article 7bis§3. Home Office, 'Guide AN: Naturalisation Booklet - The Requirements', available at www.gov.uk/government/publications/form-an-guidance. 
under the age of 16 and children born in Ireland are currently not required to register. ${ }^{174}$ Children are instead assumed to hold the same residence permission as their parents (Mannion, 2016). Due to the fact that non-EU children aged under 16 or born in Ireland are not required to register, children can face problems proving sufficient reckonable residence in the State for the purposes of making a naturalisation application, and are at increased risk of delays in accessing citizenship (McGinnity et al., 2013; Mannion, 2016; Immigrant Council of Ireland, 2016; 2018; Barrett et al., 2017; McGinnity et al., 2018; Arnold, 2020). The application form for adult applicants provides that dependent children who entered the State with their parent(s) as part of a family unit may be covered by their parent's permission for the purposes of their application if they are in secondary school. ${ }^{175}$ The form states dependent applicants may also be covered up to 23 years of age if they have been continuously dependent on their parents and progressed from secondary school in Ireland directly to third-level education. ${ }^{176}$

The Immigrant Council of Ireland observes that the lack of provision for independent residence permissions for children is especially problematic for children living with parents who do not have a formal residence status and for children in the care of the State. In the case of the latter, challenges also arise in situations where parents are unwilling or unable to cooperate with social workers on immigration and citizenship matters (Immigrant Council of Ireland, 2015; Mannion, 2016). The Immigrant Council of Ireland (2015) highlights the need for children to be able to establish their own independent status that takes account of the fact that they had lived in Ireland.

Section 35(b) of the Employment Permits (Amendment) Act 2014 provides for the removal of the exemption for those under 16 to register with the GNIB, however this provision has not yet been commenced (McGinnity et al., 2018). The Migrant Integration Strategy committed to enabling the registration of children under the age of 16 as a matter of urgency by 2018 (Department of Justice and Equality, 2017). The Department reported it planned to bring children under 16 years of age into the registration system, commencing with children aged 14-16 years by the end of 2019 (Irish Naturalisation and Immigration Service, 2018b). In the Department of Justice and Equality's report on the progress of the Strategy in 2019, the then INIS stated that registration would be introduced for minors in 2022, when responsibility for registration of non-EU nationals is fully transferred from An Garda Síochána to INIS. INIS stated this would ensure children do not have to present to Garda stations to register (Department of Justice and Equality, 2019).

174 Ibid

175 Immigration Service Delivery, 'Form 8: Application by a person of full age for naturalisation as an Irish citizen', www.irishimmigration.ie/wp-content/uploads/2019/11/form-CTZ3.pdf. 
In response to an INIS stakeholder consultation in 2018, the Immigrant Council of Ireland stressed that a child-sensitive approach should be taken to introducing the registration of children (Immigrant Council of Ireland, 2018).

\subsubsection{Intention to reside in Ireland condition}

An applicant must intend in good faith to continue to reside in Ireland after naturalisation. ${ }^{177}$ Applicants must confirm they intend to have their usual or principal place of residence in the State in the application form. In Mishra $v$ Minister for Justice, ${ }^{178}$ the court held the Minister may only consider whether an applicant intends to continue to reside in Ireland based on evidence before him. In Mishra the Minister refused naturalisation based on an assumption that the applicant did not intend to continue residence in Ireland as his doctor's qualifications were not recognised in the State. The court quashed this decision as it was based on an assumption and in contention with evidence before the Minister. ${ }^{179}$

Applicants who take up residence outside of Ireland after naturalisation are required to fill in a declaration of intention to retain Irish citizenship on an annual basis. ${ }^{180}$ As outlined in Chapter 6 of this report, residence outside of the State may form the grounds for revocation of citizenship acquired through naturalisation. Section 19 of the 1956 Act provides that the Minister can revoke the certificate of naturalisation of an individual who has resided outside of the State, or the island of Ireland, for a continuous period of seven years, and has not annually declared their name and intention to retain Irish citizenship without reasonable excuse. ${ }^{181}$ This requirement does not apply to individuals granted naturalisation as a person of Irish descent or associations. ${ }^{182}$

\subsubsection{Declaration of fidelity and loyalty condition}

The 1956 Act states that an applicant must have 'made a declaration, in the prescribed manner, of fidelity to the nation and loyalty to the State', and 'undertaken to faithfully observe the laws of the State and to respect its democratic values', before a judge of the District Court in open court or in a citizenship ceremony. ${ }^{183}$ Reflected in this declaration is the principle enshrined in the Irish Constitution that '[f]idelity to the nation and loyalty to the State are fundamental political duties of all citizens. ${ }^{184}$ The declaration of fidelity to the Irish

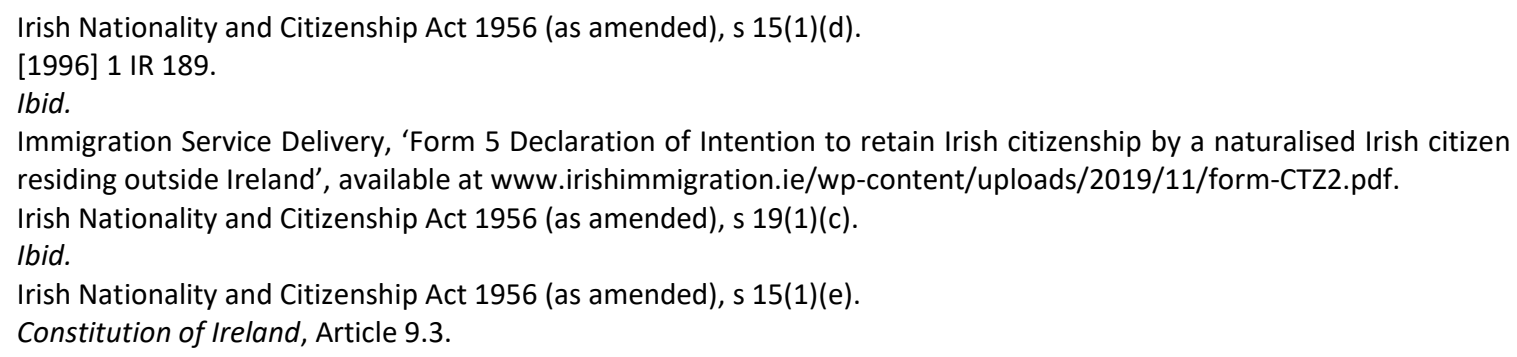


nation and loyalty to the State is typically made as part of a citizenship ceremony, which has become a mandatory part of the citizenship application process (see Section 5.2.3). The declaration is prescribed and provided to the applicant. ${ }^{185}$ The prescribed declaration reads,

\section{I... having applied to the Minister for Justice and Equality for a certificate of naturalisation, hereby solemnly declare my fidelity to the Irish nation and my loyalty to the State. ${ }^{186}$}

An applicant may also make their declaration in another manner, such as in a private ceremony, where the Minister permits for special reasons. ${ }^{187,188}$ Children are not invited to attend a citizenship ceremony and instead receive their certificate of naturalisation by post. ${ }^{189}$

Applicants in 21 other EU Member States ${ }^{190}$ and the UK are also required to make a declaration of allegiance to the State or commit to democratic values. ${ }^{191}$ In most cases, declarations are made in the context of a citizenship ceremony or before national/local authorities. In France, commitment to the State and certain values is made by way of signing the Charter of Rights and Duties of the French Citizen during a mandatory 'assimilation interview' with municipal authorities (EMN France, 2019).

\subsubsection{Other conditions}

\section{Economic requirement}

There is no statutory economic requirement for persons applying for naturalisation. However, applicants are currently required to submit information and documentation in their application on means of income and whether they have received social welfare in the three years prior to application (see Section 5.1.2).

It is reported that in the past applicants were required to have been 'selfsupporting', by showing they had not been dependent on social welfare for three

Irish Nationality and Citizenship Regulations 2011 (S.I. No. 569/2011), Regulation 9(1).

Irish Nationality and Citizenship Regulations 2011 (S.I. No. 569/2011), Form 6 and Form 7.

Irish Nationality and Citizenship Act 1956 (as amended), s 15(1)(e).

Interview with Citizenship Division, Immigration Service Delivery, Department of Justice and Equality, July 2019.

Immigration Service Delivery, 'Become an Irish citizen by naturalisation', www.irishimmigration.ie/citizenship/becomean-irish-citizen-by-naturalisation.

Austria, Belgium, Croatia, Cyprus, Czech Republic, Denmark, Estonia, France, Germany, Greece, Hungary, Italy, Latvia, Lithuania, Malta, the Netherlands, Portugal, Romania, Slovakia, Slovenia, Spain.

Information retrieved from government websites, GLOBALCIT country profiles, and templates published by EMN National Contact Points for the study Pathways to citizenship for third-country nationals in the EU, available at www.ec.europa.eu/home-affairs/what-we-do/networks/european_migration_network/reports_en. 
years prior to application (McGinnity et al., 2012). This requirement was not referred to in legislation or in publicly available guidelines (Cosgrave, 2011; Migration Policy Group and Immigrant Council of Ireland, 2013). In 2010, the then Minister for Justice and Law Reform reported that the main negative factors contributing to refusals of naturalisation applications were where the Minister was not satisfied the applicant was of good character and/or had not demonstrated they were in a position to support themselves and their dependants. ${ }^{192}$ In 2016, the Department of Justice and Equality noted that the requirement for applicants to have been self-supporting featured less strongly in decision-making, stating that a more pragmatic approach has been taken and that social welfare checks are only carried out in cases where specific queries may arise (Barrett et al., 2017). The Department of Justice and Equality stated an applicant's means of financial support forms part of the overall range of information considered by the Minister when deciding on an application. ${ }^{193}$

Citizenship law in 13 other Member States includes a requirement relating to the applicant's economic situation. ${ }^{194,195}$ In Germany applicants are required to prove they have an independent means of financial support for themselves and any dependants, without recourse to social welfare. ${ }^{196}$ In Austria, citizenship law provides that an applicant must have an adequately secure means of subsistence and applicants must demonstrate a minimum level of income to satisfy this requirement (Stiller, 2019). Applicants in Denmark must be self-supporting and cannot have received social assistance in the two years prior to the application, and for more than four months in the five years prior to application. ${ }^{197}$ Applicants in Hungary and Slovenia are required to have a sufficient means of subsistence (Dine, 2013; EMN Hungary, 2019). However, no minimum level is set out in law in Hungary (EMN Hungary, 2019). Pogonyi (2013) reports that there are no publiclyavailable guidelines on the requirement of self-subsistence, and the Hungarian authorities make a discretionary decision on the basis of the submitted documents. Applicants in Estonia are only required to prove they have a 'permanent legal income', which may be from a range of sources including employment, business activity, pension or social welfare, and no minimum income level is required (EMN Estonia, 2019). Similarly in Finland, it is a condition of naturalisation that applicants can provide a reliable account of their livelihood, which may be on the

195 Information retrieved from government websites, GLOBALCIT country profiles, and templates published by EMN National Contact Points for the study Pathways to citizenship for third-country nationals in the EU, available at www.ec.europa.eu/home-affairs/what-we-do/networks/european_migration_network/reports_en. 
basis of employment, business activities or social welfare (EMN Finland, 2019). Applicants in Latvia, Lithuania, Poland and Romania are also required to prove a legal source of income (Barbulescu, 2013; EMN Latvia, 2019; EMN Poland, 2019; Ruškyte, 2013). In Cyprus, France, Greece, Italy and Slovakia the applicant's financial situation is not included as a condition in citizenship law, however it is taken into account as a procedural requirement in the authorities' assessment of the application (EMN Cyprus, 2019; EMN France, 2019; EMN Greece, 2019; EMN Italy, 2019; EMN Slovakia, 2019).

\section{Language and civic requirements}

Ireland does not currently require applicants to meet language or civic requirements to qualify for naturalisation. In expert roundtables conducted by the Immigrant Council of Ireland in 2013 with representatives of NGOs, two academic experts and a citizenship lawyer, it was reported that some were in favour of introducing a language requirement while others were of the view that offering appropriate support to acquire language skills was more important than formal tests. Stakeholders were also of the view that vulnerable groups, such as refugees, should be exempt from language requirements, if introduced (Migration Policy Group and Immigrant Council of Ireland, 2013). A review commissioned by the then Office of the Minister for Integration and Department of Education and Science to assist in the development of a national English language policy and framework for adult immigrants in Ireland reported that, of the 98 organisations consulted, the majority were strongly against the connection between English language proficiency and eligibility for citizenship (Horwath Consulting Ireland et al., 2008). McGinnity et al. (2012) noted that NGOs expressed their concern that a citizenship test would lengthen processing times and such tests would need to be carefully devised. The possibility of introducing language and civics requirements has been raised in parliamentary debate. ${ }^{198}$ The drafts of an Immigration, Residence and Protection Bill published in 2008 and 2010, which were ultimately not enacted, included a requirement to demonstrate 'a reasonable competence for communicating in the Irish or English language' and 'reasonable efforts to integrate into Irish society' for long-term residence.

As part of commitments made under the Migrant Integration Strategy 2017-2020, the Department intends to examine the possibility of introducing a language and civics test for those seeking citizenship (Department of Justice and Equality, 2017; 2019). In a statement made to The Irish Times, the Department stated that a language requirement would help to combat some residents' lack of English after five years in Ireland (Lucey, 2018). To assist with the assessment, the Department commissioned research to examine language and civic requirements for 
naturalisation in EU Member States (Department of Justice and Equality, 2019; Groarke et al., 2020). The report found that 24 EU Member States ${ }^{199}$ and the UK have a language requirement for citizenship applicants, while 18 EU Member States ${ }^{200}$ and the UK currently require applicants to demonstrate civic knowledge or 'integration' as part of the naturalisation process. Countries with a language and/or civics requirement report that no evaluations have been conducted, therefore little is known about the impact of such requirements for naturalisation on integration. As the introduction of language or civic requirements for naturalisation would represent a significant new direction for Ireland, and potential costs are considerable, the report recommended that research into the most appropriate and fair format for requirements, and their potential impact, would be essential prior to any decision being taken on their introduction (Groarke et al., 2020).

\section{Dual citizenship}

Ireland does not require naturalisation applicants to renounce citizenship of another country in order to become an Irish citizen, along with most EU Member States (EMN, 2020a). Currently, 11 EU Member States require citizenship applicants to renounce the citizenship they hold prior to acquiring citizenship of the Member State. ${ }^{201}$

\subsection{NATURALISATION CONDITIONS FOR SPECIFIC GROUPS}

Section 16 of the 1956 Act provides that the Minister may, in his absolute discretion, grant an application for naturalisation, although the conditions for naturalisation have not been complied with, to the following applicants:

- applicants of Irish descent or Irish associations;

- parents or guardians acting on behalf of a minor of Irish descent or Irish associations;

- naturalised Irish citizens acting on behalf of their minor child;

- applicants who are, or have been, resident abroad in the public service; and

- refugees and stateless persons. ${ }^{202}$

Austria, Belgium, Bulgaria, Croatia, Czech Republic, Denmark, Estonia, Finland, France, Germany, Greece, Hungary, Italy, Latvia, Lithuania, Luxembourg, Malta, the Netherlands, Poland, Portugal, Romania, Slovakia, Slovenia and Spain. Cyprus, Ireland and Sweden do not currently have a language requirement.

Austria, Belgium, Bulgaria, Croatia, Czech Republic, Denmark, Estonia, France, Germany, Greece, Hungary, Latvia, Lithuania, Luxembourg, the Netherlands, Romania, Slovakia and Spain. Cyprus, Finland, Ireland, Italy, Malta, Poland, Portugal, Slovenia and Sweden do not currently have a civic knowledge/integration requirement.
Austria, Bulgaria, Croatia, Denmark, Estonia, Germany, Latvia, Lithuania, the Netherlands, Slovenia and Spain.

Irish Nationality and Citizenship Act 1956 (as amended), s 16. 
The application forms state that as a general rule, where section 16 applies, applicants will normally be expected to have a minimum of three years reckonable residence in the State. ${ }^{203}$

\subsubsection{Applicants of Irish descent or Irish associations}

A person is considered 'of Irish associations' if they are related by blood, affinity or adoption to, or are a civil partner of, a person who is, or was at the time of death, an Irish citizen or entitled to be an Irish citizen. ${ }^{204}$

Siblings of minor Irish citizens have not however been able to benefit from the provisions of this section in practice (Migration Policy Group and Immigrant Council of Ireland, 2013; Mannion, 2016). In Borta (a minor) v Minister for Justice and Equality, ${ }^{205}$ a child, whose mother made an application for naturalisation on her behalf, claimed Irish associations by being the sister of an Irish citizen, who was 26 months old at the time of the application. While acknowledging that the child was a person with Irish associations, the Minister did not consider those associations sufficiently strong to grant naturalisation. The Court of Appeal held, in quashing the Minister's decision, that it was incumbent on the Minister to explain why the strength of the child's associations was insufficient to grant naturalisation in circumstances where it was uncontested the child had met the statutory condition.

\subsubsection{Child of naturalised Irish citizen}

There are no provisions in Irish law that enable children to automatically acquire Irish citizenship on the naturalisation of their parent(s). The 1956 Act provides that the Minister may waive certain or all conditions of naturalisation for a child of a naturalised Irish citizen. ${ }^{206}$ The general requirement introduced by the Minister is that children of naturalised Irish citizens must have been legally resident for three years prior to an application for naturalisation being made on their behalf. ${ }^{207}$

\subsubsection{Refugees and stateless persons}

No explicit policy in relation to the waiving of requirements for the naturalisation of refugees has been published by the Department. In practice, the five-year residence requirement is waived, at the discretion of the Minister, for persons with refugee status, who are viewed as eligible to apply for citizenship after three years' 
residence. ${ }^{208}$ Residence is calculated from arrival in the State. ${ }^{209}$ Unlike in the case of refugees, requirements are not waived for beneficiaries of subsidiary protection. ${ }^{210}$

Two of the five years' required residence are also waived for stateless persons in Ireland. ${ }^{211}$ This is in line with Ireland's obligations under the 1954 Convention relating to the Status of Stateless Persons, which provides that the State should facilitate the naturalisation of stateless persons as far as possible, in particular by expediting naturalisation procedures and reducing as far as possible the charge and costs of such proceedings. ${ }^{212}$ However, UNHCR, NGOs and commentators state that the lack of a statelessness determination procedure poses an obstacle to stateless persons applying for naturalisation in practice on the basis of the provisions of the 1956 Act that allow for a waiver specific to stateless persons (Migration Policy Group and Immigrant Council of Ireland, 2013; UNHCR, 2014; Immigrant Council of Ireland, European Network on Statelessness and Institute on Statelessness and Inclusion, 2015; Arnold, 2020; EMN, 2020b).

\subsubsection{Spouses and civil partners of Irish citizens}

Section 15A of the 1956 Act sets out requirements specific to the acquisition of citizenship by spouses or civil partners of Irish citizens. Similar to provisions applicable to all naturalisation applicants, the applicant spouse or civil partner must be of full age, good character, intend in good faith to reside in Ireland after naturalisation, and declare fidelity to the nation and loyalty to the State. ${ }^{213}$ The applicant spouse or civil partner and Irish citizen must also be in a recognised marriage or civil partnership to each other for at least three years and living together. ${ }^{214}$ The residence requirement is however reduced for an applicant spouse or civil partner. An applicant spouse or civil partner must have resided in Ireland for three out of the previous five years, including one year of continuous residence immediately prior to the application. ${ }^{215}$

\subsection{DATA ON NATURALISATION IN IRELAND}

Data on the number of people applying for, and acquiring, citizenship have been reported sporadically by the Department of Justice and Equality (the Department)

Citizens Information, 'Becoming an Irish citizen through naturalisation', www.citizensinformation.ie/en/moving_country/irish_citizenship/becoming_an_irish_citizen_through_naturalisation .html. Ibid.

210 Parliamentary Question [44414/17], 19 October 2017, available at www.oireachtas.ie.

211 Citizens Information, 'Becoming an Irish citizen through naturalisation', www.citizensinformation.ie/en/moving_country/irish_citizenship/becoming_an_irish_citizen_through_naturalisation .html.

2121954 Convention relating to the Status of Stateless Persons, Article 32

213 Irish Nationality and Citizenship 1956 (as amended), s 15A(1)(a), (b), (g) and (h).

214 Irish Nationality and Citizenship 1956 (as amended), s 15A(c) and (d).

215 Irish Nationality and Citizenship 1956 (as amended), s 15A(e) and (f). 
in its annual reports since 2000. The Department published data on the number of applications made in its annual reports in 2000 to 2002, 2005, 2007 to 2011, and application data were published by the Irish Naturalisation and Immigration Service in 2017 and 2018. Data on the number of certificates of naturalisation issued were reported in the Department's annual reports in 2000 to 2002 and 2005 to 2010, and in the Irish Naturalisation and Immigration Service's annual reports from 2015 to 2018.

Reference is made in the following sections to data published by the Department. The Department notes that data were correct at the time of publication, however changes may have occurred to data previously reported in light of data cleansing and efforts to improve data. ${ }^{216}$ In its Service Improvement Plan 2018-2020, the Department observed that:

limited focus on data quality standards and controls has led to trust issues with the current dataset, which is compounded by high volumes of paper handling and paper file management. (Irish Naturalisation and Immigration Service, 2018b)

The Department committed to improve reporting, data analysis and statistical capabilities of the Irish Naturalisation and Immigration Service (ibid.).

Data published by the Department on applications made and granted have become more detailed in recent years. While application numbers for 2015 and 2016 were not reported, the number of citizenship certificates issued and the most common five nationalities that acquired citizenship in those years were reported (Irish Naturalisation and Immigration Service, 2016; 2017). The Migrant Integration Strategy, published in 2017, stipulates in Action 9 that statistics on applications for citizenship disaggregated by age, gender and nationality will be published annually (Department of Justice and Equality, 2017). In the Immigration in Ireland: Annual Review 2017, the number of applications for citizenship made in 2017 disaggregated by top ten nationalities and age group were published. In addition, the total number of citizenship certificates issued and the most common ten nationalities awarded citizenship were reported (Irish Naturalisation and Immigration Service, 2018). In the Immigration in Ireland: Annual Review 2018, data on both applications made and certificates issued in 2018, disaggregated by the most common 20 nationalities, age and sex, were published (ibid.).

In addition to annual reports by the Department and Immigration Service Delivery, data on the number of people granted Irish citizenship by the Department have 
been reported to Eurostat on an annual basis since 1998 by the Department, in line with EU statistics reporting requirements. ${ }^{217}$ Data reported to Eurostat by the Department have been disaggregated by nationality since 2005, by sex since 2008 and by age since 2009. ${ }^{218}$ Supplementary data on the acquisition of citizenship through naturalisation in Ireland have also been reported in the Economic and Social Research Institute's Monitoring Report on Integration since 2010 (McGinnity et al., 2018a) and on an ad hoc basis in response to parliamentary questions. ${ }^{219}$

\subsubsection{Applications made, certificates issued and refusals}

Figure 4.1 shows the trends over time since 2006 in the number of applications received by the Department and the number of naturalisation certificates issued. ${ }^{220}$ Table A.1 included in the Appendix to this report provides a detailed breakdown of figures on applications received by the Department and certificates issued annually since 2006.

Data on naturalisation applications provided by the Department for this study are broken down into 'total applications received' and 'valid applications received'. Valid applications refer to applications that are deemed to be correctly completed, that include the required supporting documentation, and that are therefore accepted for processing. The Department noted that, from 2008 to 2013, significant numbers of applications were returned to applicants as the applications were deemed incomplete for reasons such as a lack of supporting documentation or incorrect declarations. ${ }^{221}$ The figures for 'total applications received' in Figure 4.1 therefore include double-counting of applications in cases where an application was first deemed incomplete and subsequently resubmitted in the same year. ${ }^{222}$ While figures on valid applications may represent a more accurate picture of the number of people that applied for naturalisation in a given year, the figures on total applications provide an insight into the volume of applications the Department receives for processing each year.

Data reported to Eurostat by the Department encompass data on applications for citizenship granted by Immigration Service Delivery. Data reported to Eurostat by the Department of Justice and Equality include data on naturalisation certificates, in addition to very small numbers of post-nuptial certificates and certificates of nationality issued pursuant to Section 28A of the 1956 Act. The vast majority of figures on the acquisition of citizenship reported to Eurostat relate to certificates of naturalisation.

218 See Eurostat, 'Acquisition of citizenship by age group, sex and former citizenship [migr_acq]', http://appsso.eurostat.ec.europa.eu/nui/show.do?dataset=migr_acq\&lang=en.

219 Parliamentary Question [1069/07], 31 January 2007, available at www.kildarestreet.com/wrans/?id=2007-0131.998.0; Parliamentary Question [13761/19], 26 March 2019, available at www.oireachtas.ie/en/debates/question/2019-03-26/554. annual report in 2000. However, due to the subsequent transfer to a new IT system and data cleansing, comparable data on total and valid applications received and certificates issued are not available in the years prior to 2006. 
FIGURE 4.1 NATURALISATION APPLICATIONS RECEIVED AND CERTIFICATES ISSUED IN IRELAND 2006-2018

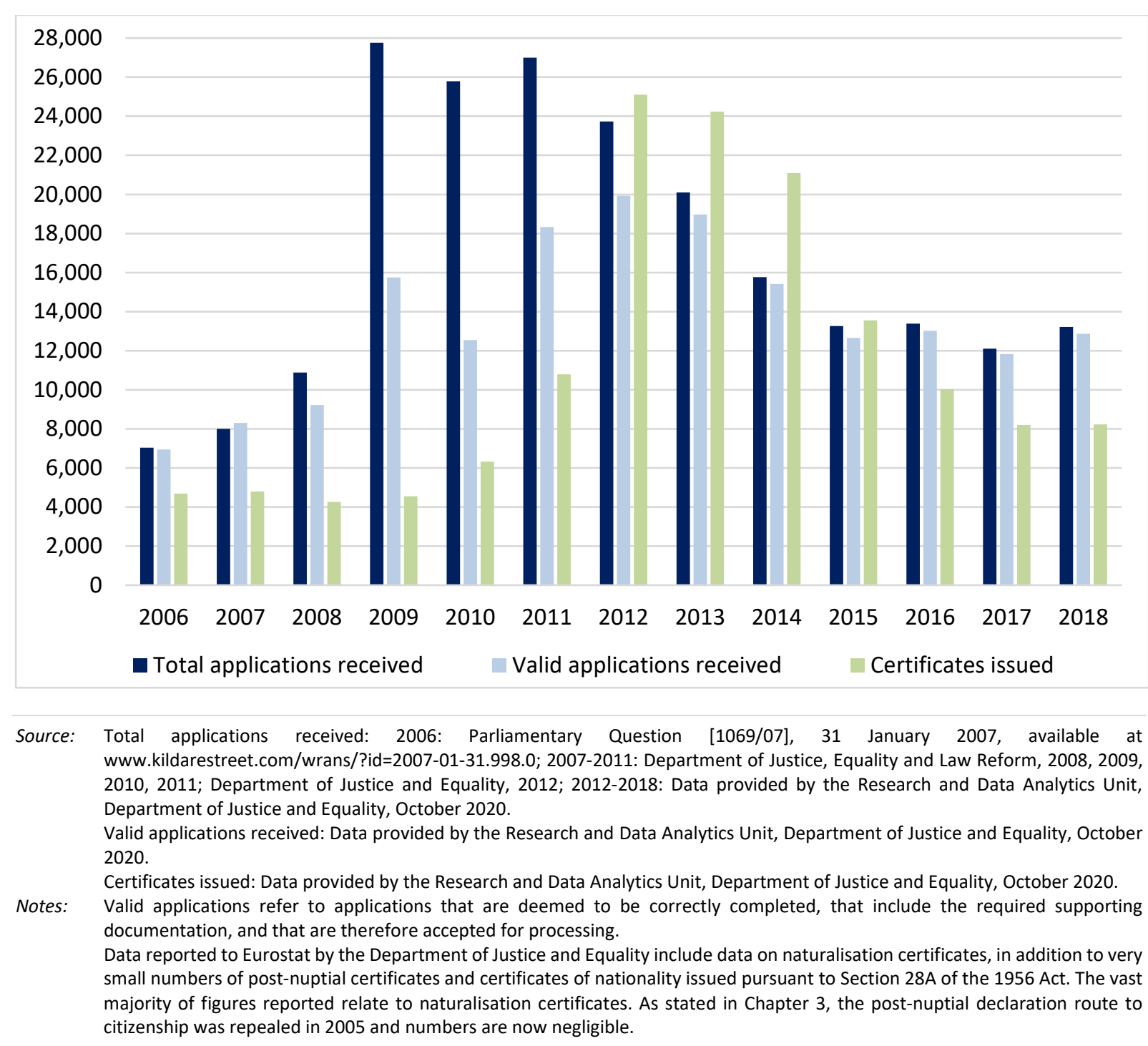

Figure 4.1 (and Table A.1) shows that over 145,800 people acquired Irish citizenship through naturalisation between 2006 and 2018. It is estimated that over 18,100 total applications for naturalisation were made between 2000, when annual data were first published, and $2005 .{ }^{223}$ It is estimated that over 7,200 naturalisation certificates were issued between 2000 and 2005. 224

The number of people who applied for citizenship through naturalisation in Ireland grew steadily in the early 2000s, during a period in which Ireland experienced an unprecedented increase in immigration in the context of EU expansion in 2004 and the economic boom from the mid-1990s. In the early 2000s, the Department reported that the priority attached to developing the asylum system in response

223 Department of Justice, Equality and Law Reform, 2001, 2003, 2006; Parliamentary Question [1069/07], 31 January 2007, available at www.kildarestreet.com/wrans/?id=2007-01-31.998.0.

224 Data provided by the Research and Data Analytics Unit, Department of Justice and Equality, October 2020. 
to increased asylum applications meant sufficient resources were not available to meet increased demand in other immigration services including citizenship. As a result, backlogs in dealing with naturalisation applications and longer processing timeframes arose (Department of Justice, Equality and Law Reform, 2006b).

The total number of applications for naturalisation jumped significantly in the years between 2008 and 2011, reflecting the growth in the number of people who had migrated to Ireland becoming eligible to apply for citizenship.

By 2011, approximately 22,000 citizenship applications were awaiting decision, around 17,000 of which had been awaiting decision for a period of more than six months (McGinnity et al., 2012). The then Minister committed to reducing the backlog in processing and cutting processing times, including by increasing the number of staff, introducing new application forms, introducing streamlined and accelerated checking procedures for certain categories of applicants and the recruitment of interns. ${ }^{225}$ The implementation of more efficient processing procedures contributed to an increase in the number of cases decided and a reduction of the backlog. ${ }^{226}$ The Department reported that the number of cases decided annually had more than tripled from 2010, when fewer than 8,000 applications were decided, to 2012 when some 25,000 applications were decided (Department of Justice and Equality, 2013). More than 30,000 applications were decided in 2013 (Department of justice and Equality, 2014). Figure 4.1 (and Table A.1) shows that the number of naturalisation certificates issued annually jumped from 10,791 in 2011 to 25,098 in 2012.

Improvements in the quality of applications received since 2011 also played a role in the increase in processing and certificates being issued (McGinnity et al., 2013). As stated above, significant numbers of applications deemed incomplete were returned to applicants notably in the period from 2008 to 2013. The Department reported in 2009 that over 12,000 applications submitted were invalid (Department of Justice, Equality and Law Reform, 2010). The then Minister stated application forms were 'unnecessarily complex and obtuse' and therefore introduced new application forms in 2011 in an effort to reduce the numbers of forms incorrectly completed and to contribute to more efficient processing times. $^{227}$ The number of applications submitted and certificates issued subsequently decreased gradually between 2012 and 2017. The decrease may

225 Department of Justice and Equality, 'Minister Shatter introduces major changes to citizenship application processing regime', Press Release, 16 June 2011, www.justice.ie/en/JELR/Pages/PR11000088. follow', 3 January 2012, www.inis.gov.ie; Department of Justice and Equality, 'Immigration in Ireland - 2012 in Review', 2 January 2013, www.inis.gov.ie.

227 Department of Justice and Equality, 'Minister Shatter introduces major changes to citizenship application processing regime', Press Release, 16 June 2011, www.justice.ie/en/JELR/Pages/PR11000088. 
reflect a decline in the number of non-EU nationals residing in Ireland during the 2008-2012 recession and knock-on decline in numbers with sufficient reckonable residence, as well as the clearing of a large part of the backlog following the introduction of processing improvements in 2011 (McGinnity et al., forthcoming). The total number of applications submitted increased by 9 per cent to 13,215 in 2018 , representing the first increase in total applications since 2009. As reflected in Figure 4.1, the Department confirmed that while some invalid applications are still returned to applicants, numbers are not as significant as those returned to applicants in previous years. ${ }^{228}$

Data on the number of refusals issued are not regularly published (Fahey et al., 2019). Refusal data were reported in the 2005, 2009 and 2010 annual reports published by the Department (Department of Justice, Equality and Law Reform, 2006a; 2010; Department of Justice and Law Reform, 2011). In the Monitoring Report on Integration, the Economic and Social Research Institute has reported data provided by the Department on refusals since 2010 .

Updated figures provided by the Department on applications refused during the study period between 2014 and 2018 are shown in Table 4.1. As data on applications disaggregated by nationality are not publicly available, it is not possible to determine the proportion of refusals issued to non-EU nationals compared to EU nationals.

The number of naturalisation applications refused were stable between 2014 and 2017. The ratio of applications refused to certificates issued was also stable between 2014 and 2017, ranging from 3 to 6 per cent. These ratios are significantly lower than ratios in previous years, such as in $\mathbf{2 0 1 0}$ when the ratio of applications refused to certificates issued was reported at 20 per cent (McGinnity et al., 2018a). However, the number of refusals issued more than doubled in 2018, with the ratio of applications refused to certificates issued jumping significantly to 15 per cent. 


\begin{tabular}{|l|r|r|r|r|r|}
\hline & 2014 & 2015 & 2016 & 2017 & 2018 \\
\hline Refusals issued to non-EU nationals & 574 & 414 & 418 & 437 & 920 \\
\hline Refusals issued to EU nationals & 58 & 71 & 63 & 77 & 323 \\
\hline Total refusals issued & 632 & 485 & 481 & 514 & 1,243 \\
\hline
\end{tabular}

Source: Data received from the Research and Data Analytics unit, Department of Justice and Equality, October 2020.

\subsubsection{Profile of people acquiring citizenship through naturalisation}

The Department first published figures on citizenship acquisition disaggregated by nationality in 2015. Since 2005, Eurostat has published data reported to it by the Department on the number of people that acquired citizenship by nationality. Data in Figure 4.2 show that the majority of people acquiring Irish citizenship are non-EU nationals. ${ }^{229}$ However, Figure 4.2 shows that the number of non-EU nationals acquiring Irish citizenship annually has fallen significantly in recent years, while naturalisation has been gradually increasing among EU nationals. The share of non-EU nationals among all persons acquiring Irish citizenship decreased from a peak of 96 per cent in 2011 to 52 per cent in 2018.

FIGURE 4.2 ACQUISITION OF CITIZENSHIP BY EU AND NON-EU NATIONALITY IN IRELAND 2014-2018

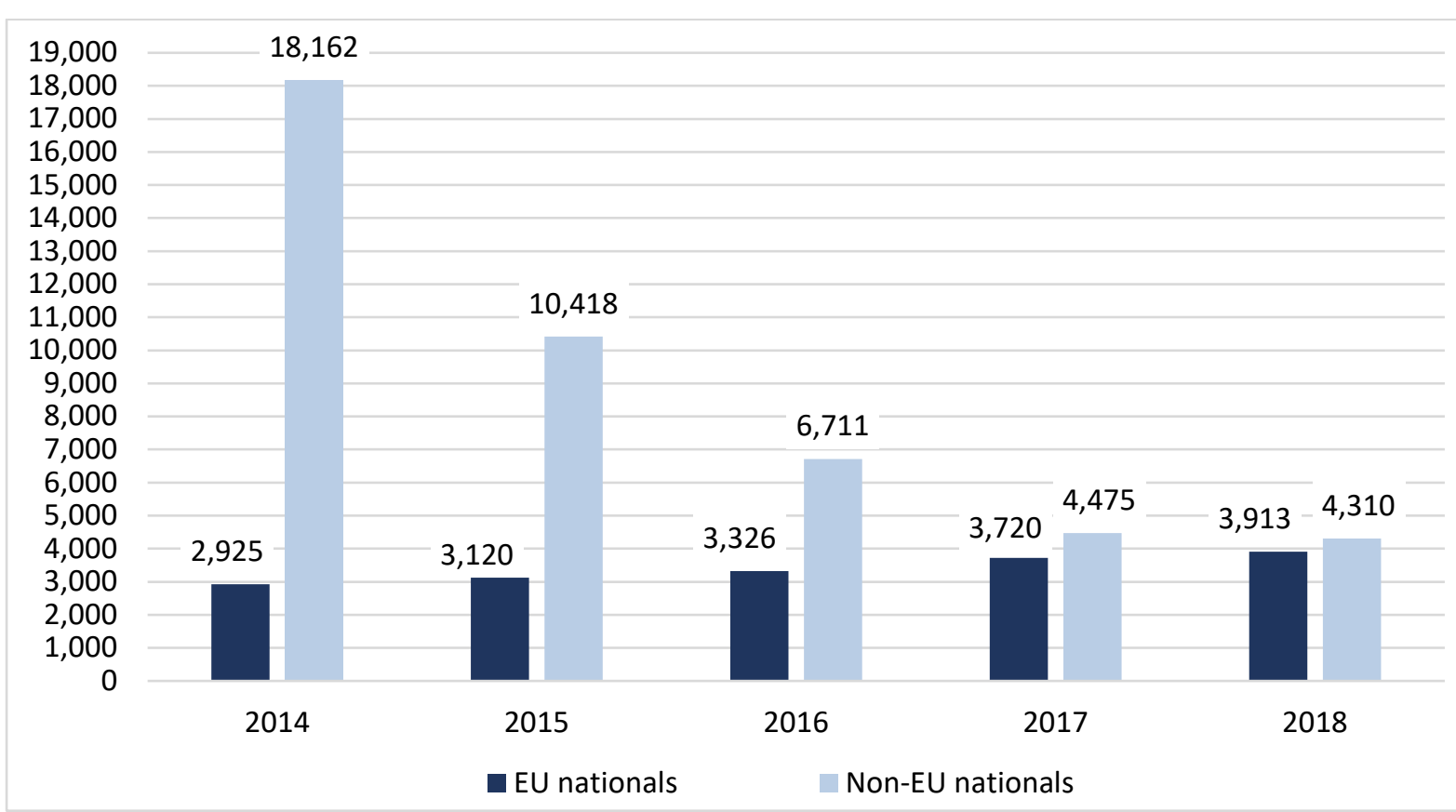

Source: Eurostat, 'Acquisition of citizenship by age group, sex and former citizenship [migr_acq]', http://appsso.eurostat.ec.europa.eu/nui/show.do?dataset=migr_acq\&lang=en (accessed 29 July 2020).

Notes: Data reported to Eurostat by the Department of Justice and Equality include data on naturalisation certificates, in addition to very small numbers of post-nuptial certificates and certificates of nationality issued pursuant to Section $28 \mathrm{~A}$ of the 1956 Act. The vast majority of figures reported relate to naturalisation certificates. 
The most common nationalities among non-EU nationals acquiring Irish citizenship through naturalisation since 2005 are, in order, Nigeria, India, the Philippines, Pakistan, US and China. ${ }^{230}$ The most common nationalities among EU nationals acquiring Irish citizenship through naturalisation since 2005 are, in order, Poland, Romania, UK, Latvia, Hungary and Lithuania. ${ }^{231}$

As stated above, data on naturalisation disaggregated by sex were first published by the Department in its annual reporting in 2018. However, data on the acquisition of citizenship through naturalisation disaggregated by sex have been reported to Eurostat by the Department since 2008.

Figure 4.3 presents updated data provided by the Department for this study on the acquisition of citizenship through naturalisation disaggregated by sex. A slightly higher proportion of people acquiring citizenship through naturalisation were female in most years between 2014 and 2018, though differences are small. However, this varies across broad nationality groups. In recent years a slightly higher proportion of non-EU nationals acquiring citizenship through naturalisation from 2015 to 2018 were male, while a slightly higher proportion of EU nationals acquiring Irish citizenship from 2016 to 2018 were female. ${ }^{232}$ [migr_acq]', http://appsso.eurostat.ec.europa.eu/nui/show.do?dataset=migr_acq\&lang=en (accessed 29 July 2020). 
FIGURE 4.3 ACQUISITION OF CITIZENSHIP BY SEX AND EU/NON-EU NATIONALITY IN IRELAND 2014-2018

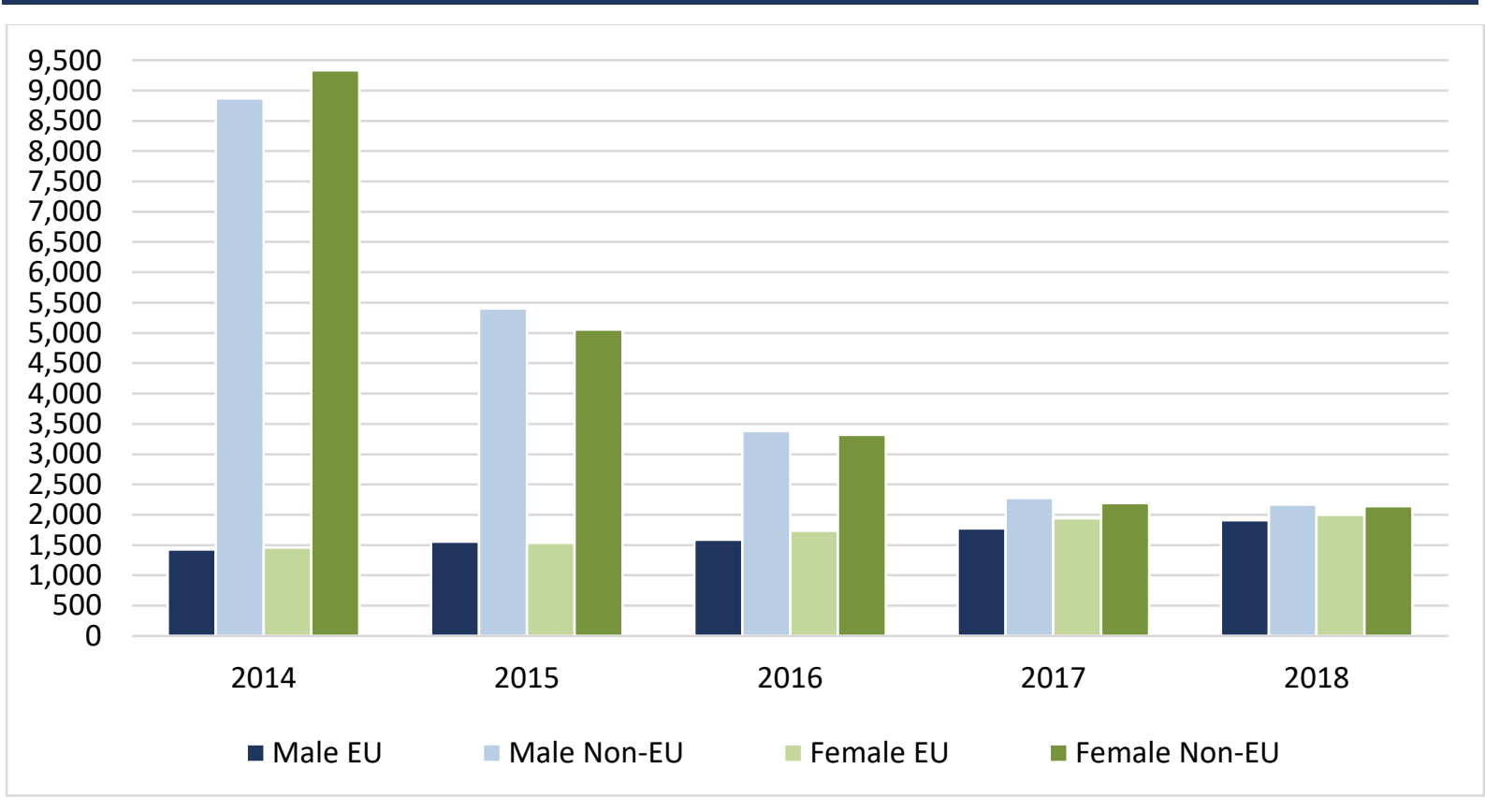

Source: Data received from the Research and Data Analytics unit, Department of Justice and Equality, October 2020.

Data are based on Eurostat reporting parameters: Eurostat, 'Acquisition of citizenship by age group, sex and former citizenship [migr_acq]', http://appsso.eurostat.ec.europa.eu/nui/show.do?dataset=migr_acq\&lang=en.

Notes: Data do not include where gender is not specified. Data reported to Eurostat by the Department of Justice and Equality include data on naturalisation certificates, in addition to very small numbers of post-nuptial certificates and certificates of nationality issued pursuant to Section $28 \mathrm{~A}$ of the 1956 Act. The vast majority of figures reported relate to naturalisation certificates.

The Department first published data on naturalisation disaggregated by age in its annual reporting in 2017. In its Annual Review 2017, INIS reported age by four broad age categories (0-17, 18-34, 35-64 and 65+), while in the Annual Review 2018 age was broken down into two broad categories (0-17 and 18+). The Department has reported data on the acquisition of citizenship through naturalisation disaggregated by age to Eurostat since 2009. Eurostat disaggregates into 20 five-year age categories in addition to five broader age categories (less than 15 years, $15-64,65+, 85+$ and $100+)$. Figure 4.4 presents updated data provided by the Department for this study on the number of people who acquired citizenship disaggregated by age from 2014 to 2018, based on Eurostat age categories. ${ }^{233}$

People aged 35 to 64 represented the largest proportion of people acquiring Irish citizenship through naturalisation in each year. People aged 20 to 34 represented the second largest proportion of people acquiring Irish citizenship in most years apart from 2014, when a slightly larger number of people aged 19 and below acquired Irish citizenship than those aged 20 to 34 . People aged 65 and over

233 Eurostat data for the age groups 0-19, 20-34, 35-64, and 65 and over, are used. The use of these groups was informed by the categories used by the Department in its reporting of data disaggregated by age in the Annual Review 2017. Categories adopted by Eurostat do not provide separate figures on the acquisition of citizenship by children up to the age of 18. The categories 0-19 and 20-34 were therefore used. See: Eurostat, 'Acquisition of citizenship by age group, sex and former citizenship [migr_acq]',

http://appsso.eurostat.ec.europa.eu/nui/show.do?dataset=migr_acq\&lang=en. 
represent the lowest proportion of people acquiring Irish citizenship each year. The number of people in the age groups 19 and below and 20 to 34 decreased gradually from 2014 to 2018. While people in the age groups 35 to 64, and 65 and over, similarly decreased from 2014, the 35 to 64 age group saw a slight increase by 4 per cent in 2018 and the 65 and over age group more than doubled between 2016 and 2017 , and increased by a further 44 per cent in 2018. The number of naturalisations among people aged 65 and over represented less than 1 per cent of all naturalisations in each year up to 2015 , however naturalisations among this age group had increased to 3 per cent by 2018.

A larger proportion of non-EU nationals acquiring citizenship are aged up to 19 years when compared to EU nationals, with 21 per cent of non-EU nationals naturalising in 2018 aged 19 and under, compared to 11 per cent of EU nationals naturalising in $2018 .{ }^{234} \mathrm{~A}$ larger proportion of people aged 65 and over acquiring citizenship are EU nationals: 6 per cent of EU nationals that naturalised in 2018 were aged 65 and over, compared to 1 per cent of non-EU nationals that naturalised in 2018. ${ }^{235}$

FIGURE 4.4 ACQUISITION OF CITIZENSHIP BY AGE AND EU/NON-EU NATIONALITY IN IRELAND 2014-2018

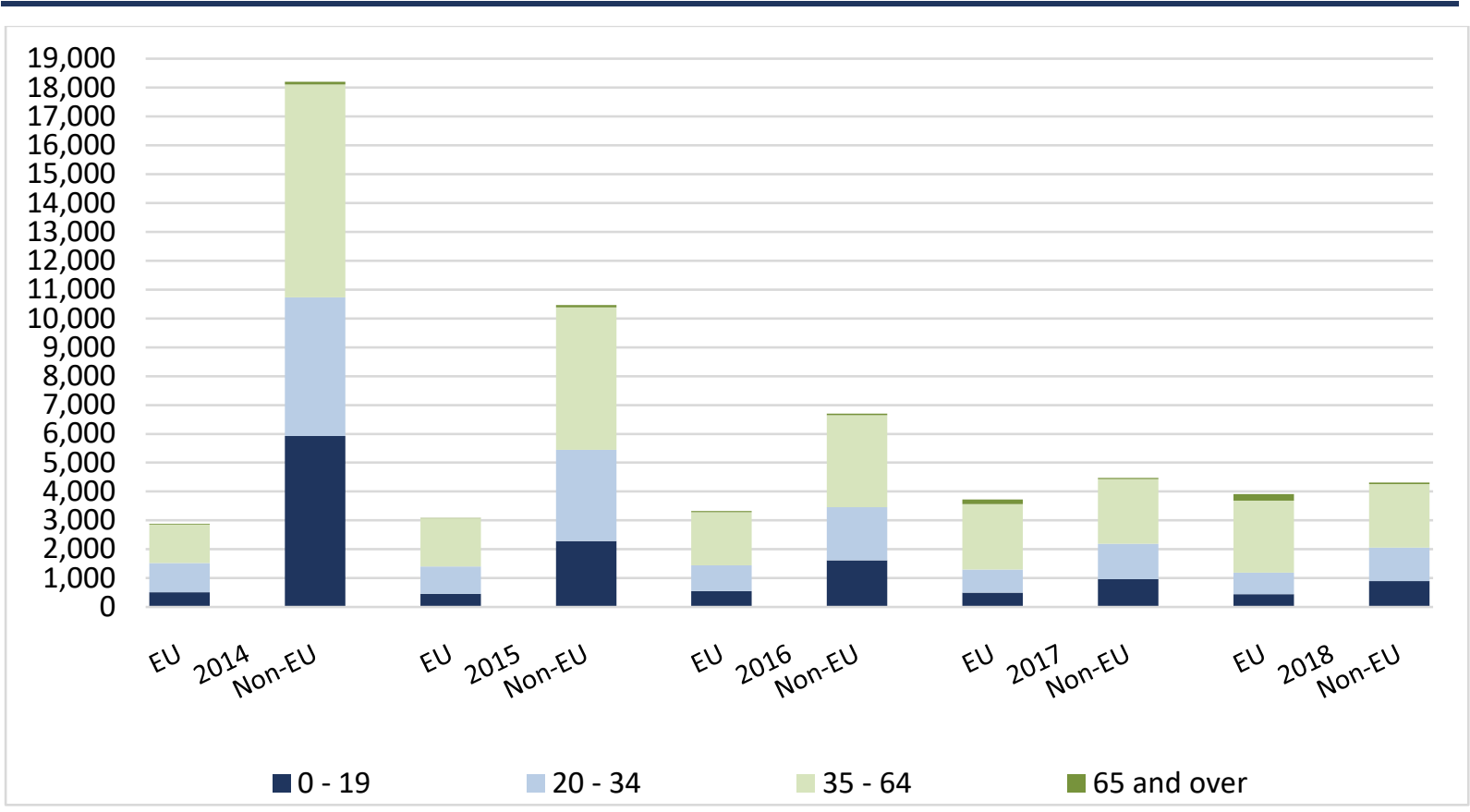

Source: Updated data pursuant to Eurostat reporting parameters was received from the Research and Data Analytics unit, Department of Justice and Equality, October 2020.

Notes: Data do not include where gender is not specified. Data reported to Eurostat by the Department of Justice and Equality include data on naturalisation certificates, post-nuptial certificates in addition to applications for a certificate of nationality made by individuals pursuant to Section 28A of the 1956 Act.

\footnotetext{
234 Authors' own calculations using data on acquisition of citizenship disaggregated by age and nationality provided by the Research and Data Analytics unit, Department of Justice and Equality, October 2020. 


\subsubsection{Modes of naturalisation}

Data published by the Department on applications made and certificates issued are not disaggregated by the mode or type of naturalisation. For example, data on the number of people acquiring citizenship on the basis of marriage or civil partnership to an Irish citizen, and data on the basis on which children under the age of 18 apply for naturalisation, are not regularly published by the Department. Data provided by the Department for the purpose of this study and data reported in other sources provide some information on the modes of naturalisation through which people have acquired citizenship.

As stated in Chapter 3, non-Irish nationals who are the spouse or civil partner of an Irish citizen may apply for naturalisation under Section 15A of the 1956 Act. A significant proportion of people who naturalise do so on the grounds of marriage or civil partnership to an Irish citizen. Table 4.2 provides data provided by the Department for this study on the number of people who have acquired Irish citizenship through naturalisation on the basis of marriage or civil partnership between 2014 and 2018. The majority of people naturalising on the basis of marriage or civil partnership are non-EU nationals. The data also show that more women than men from non-EU countries acquired naturalisation on the basis of marriage or civil partnership in this period. Naturalisation on the basis of marriage or civil partnership represented 15 per cent of total naturalisation certificates issued in 2014. The share increased to 20 per cent of all naturalisation certificates issued in 2015 and 20 per cent in 2016, and reduced again to 18 per cent in 2017 and 2018.

TABLE 4.2 ACQUISITION OF CITIZENSHIP THROUGH NATURALISATION ON THE BASIS OF MARRIAGE OR CIVIL PARTNERSHIP IN IRELAND 2014-2018

\begin{tabular}{|l|r|r|r|r|r|}
\hline & $\mathbf{2 0 1 4}$ & $\mathbf{2 0 1 5}$ & $\mathbf{2 0 1 6}$ & $\mathbf{2 0 1 7}$ & $\mathbf{2 0 1 8}$ \\
\hline Male non-EU nationals & 1,255 & 1,087 & 777 & 481 & 426 \\
\hline Female non-EU nationals & 1,766 & 1,380 & 1,047 & 664 & 674 \\
\hline Total non-EU nationals & 3,031 & 2,467 & 1,824 & 1,145 & 1,100 \\
\hline Total naturalisation through marriage/civil partnership & $\mathbf{3 , 1 6 6}$ & $\mathbf{2 , 6 4 3}$ & $\mathbf{2 , 0 0 4}$ & $\mathbf{1 , 4 5 6}$ & $\mathbf{1 , 4 6 1}$ \\
\hline Total naturalisation certificates issued & $\mathbf{2 1 , 0 9 4}$ & $\mathbf{1 3 , 5 5 2}$ & $\mathbf{1 0 , 0 3 0}$ & $\mathbf{8 , 1 9 2}$ & $\mathbf{8 , 2 2 1}$ \\
\hline
\end{tabular}

Source: Data received from the Research and Data Analytics unit, Department of Justice and Equality, October 2020.

Table 4.3 presents a breakdown of the basis on which children under the age of 18 acquired Irish citizenship through naturalisation between 2014 and 2018. These data were first reported by the Minister for 2017 and 2018 in response to a parliamentary question in $2019 .{ }^{236}$ Updated data were provided by the 
Department for the purpose of this study. These data show that the large majority of children under 18 naturalise on the basis of an application made on their behalf by their parent or guardian who had previously naturalised in Ireland (see Section 4.1.1 of this report).

TABLE 4.3 MODES OF NATURALISATION OF CHILDREN IN IRELAND 2014-2018

\begin{tabular}{|l|r|r|r|r|r|}
\hline \multicolumn{1}{|c|}{ Mode of naturalisation } & $\mathbf{2 0 1 4}$ & $\mathbf{2 0 1 5}$ & $\mathbf{2 0 1 6}$ & $\mathbf{2 0 1 7}$ & $\mathbf{2 0 1 8}$ \\
\hline Applicant with naturalised Irish parent & 5,692 & 2,381 & 1,861 & 1,269 & 1,135 \\
\hline Applicant with Irish associations & 67 & 55 & 44 & 25 & 36 \\
\hline $\begin{array}{l}\text { Applicant born in Ireland after January } \mathbf{2 0 0 5} \\
\text { and not entitled to citizenship at birth }\end{array}$ & 191 & 72 & 102 & 53 & 76 \\
\hline Refugee with naturalised Irish parent & 143 & 55 & 54 & 48 & 12 \\
\hline Refugee with Irish associations & 2 & 1 & 2 & 0 & 2 \\
\hline Total & $\mathbf{6 , 0 9 5}$ & $\mathbf{2 , 5 6 4}$ & $\mathbf{2 , 0 6 3}$ & $\mathbf{1 , 3 9 5}$ & $\mathbf{1 , 2 6 1}$ \\
\hline
\end{tabular}

Source: Data received from the Research and Data Analytics unit, Department of Justice and Equality, October 2020.

Data on the naturalisation of refugees since 2005 were reported by the Minister in response to a parliamentary question in 2019. ${ }^{237}$ Table 4.4 presents the number of people with refugee status in Ireland who naturalised between 2014 and 2018, based on updated data provided by the Department for this study. The proportion of people with refugee status among the total number of non-EU nationals naturalising in each year decreased overall from 3 per cent in 2014 to 1 per cent in 2018.

\begin{tabular}{|l|c|c|c|c|c|}
\hline $\begin{array}{l}\text { Number of people with refugee status acquiring } \\
\text { citizenship through naturalisation }\end{array}$ & 2014 & 2015 & 2016 & 2017 & 2018 \\
\hline
\end{tabular}

Source: Data received from the Research and Data Analytics unit, Department of Justice and Equality, October 2020. 



\section{CHAPTER 5}

\section{The naturalisation procedure}

The legal conditions for naturalisation, as set out in the Irish Nationality and Citizenship Act 1956 (as amended) (the 1956 Act), determine which migrants resident in Ireland may apply for citizenship. Since 2005 the Irish Naturalisation and Immigration Service (INIS), now known as Immigration Service Delivery (ISD), within the Department of Justice and Equality (the Department) is responsible for performing the administrative functions of the Minister for Justice and Equality (the Minister) in relation to citizenship.

Huddleston (2013) highlights that administrative procedures are important for the implementation of legal provisions and guarantee access to citizenship in practice.

This chapter will discuss the naturalisation procedure: how individuals formally apply for naturalisation and how applications are processed by the Department. The chapter will address in particular how applicants must prove they meet the legal requirements for naturalisation, how the Minister comes to a decision on applications, judicial oversight of the decision-making process and the procedure for revoking a naturalisation certificate. It will also discuss recent measures adopted by the Department in response to the COVID-19 pandemic in 2020 in respect of applications for naturalisation.

\subsection{APPLYING FOR NATURALISATION}

Applicants for naturalisation must fully complete the appropriate application form (see Section 5.1.1). Applicants must submit the form with the application fee and all relevant documents by post to the Citizenship Division of the Department of Justice and Equality.

The application procedure for naturalisation is not currently digitised. In its Service Improvement Plan 2018-2020, the Department stated that due to the limited interoperability of ICT systems and a heavy dependency on paper-based processing, processing times were longer than they could be (Irish Naturalisation and Immigration Service, 2018b). The Department made a broad commitment to review all forms within the Irish Naturalisation and Immigration Service with a view to moving to online forms (ibid.). Digitisation of application forms was expected to be rolled out mid-2020, along with online payments. ${ }^{238}$ Applicants for citizenship 
in five EU Member States are currently able to submit applications using an online application form or via email (EMN, 2020a). ${ }^{239}$

\subsubsection{Application forms}

Application forms are available on the Department of Justice and Equality's website. There are four types of application form:

- Application by a person of full age (Form 8);

- Application by a naturalised Irish citizen on behalf of their minor child (Form 9);

- Application on behalf of a minor of Irish descent or associations (Form 10); and

- Application on behalf of a minor born in the State from 1 January 2005 and not entitled to Irish citizenship at birth (Form 11). ${ }^{240}$

\section{Statutory declaration}

The applicant must complete a statutory declaration as part of the application form, the signing of which indicates the applicant understands the application form and that the facts provided in the application form are true and correct to the best of the applicant's knowledge. In the case of adult applicants and an application on behalf of a minor born in the State but not entitled to Irish citizenship at birth, the statutory declaration must be signed in the presence of an authorised person, or witness, such as a solicitor, Peace Commissioner, Notary public or Commissioner for Oaths. Applicants applying on the basis of marriage or civil partnership to an Irish citizen must also have their spouse or civil partner complete the spousal or civil partner declaration in the application form in the presence of the witness. ${ }^{241}$ An application by a naturalised Irish citizen on behalf of their minor child and an application on behalf of a minor of Irish descent or associations must be signed by the parent, guardian or person in loco parentis to the child only. ${ }^{242}$

\subsubsection{Documentation requirements}

Huddleston (2013) noted that documentation requirements may make it easier or more difficult for applicants to prove they meet the eligibility requirements. Most countries in Europe are reported to have complicated requirements for

Estonia, Finland, Italy, Spain, Sweden and the UK. Irish Nationality and Citizenship Regulations 2011 (S.I. No. 569/2011); Immigration Service Delivery, 'Naturalisation Application Forms', www.irishimmigration.ie/citizenship/naturalisation-application-forms.

Immigration Service Delivery, 'Form 8: Application by a person of full Age for naturalisation as an Irish citizen', www.irishimmigration.ie/wp-content/uploads/2019/11/form-CTZ3.pdf; Immigration Service Delivery, 'Form 11: Application by a parent or guardian of, or person who is in loco parentis to a minor born in the state who did not at birth have an entitlement to Irish citizenship under Section 6A of the Act of 1956', www.irishimmigration.ie/wpcontent/uploads/2019/11/form-CTZ6.pdf.

Immigration Service Delivery, 'Form 9: Application for a Certificate of Naturalisation by a naturalised Irish citizen acting on behalf of his/her minor child', www.irishimmigration.ie/wp-content/uploads/2019/11/form-CTZ4.pdf; Immigration Service Delivery, 'Form 10: Application for a Certificate of Naturalisation by a Parent or Guardian acting on behalf of a minor of Irish decent or Irish Associations', www.irishimmigration.ie/wp-content/uploads/2019/11/form-CTZ5.pdf. 
documentation from countries of origin, few alternatives to proving identity, and few legal exemptions from documentation requirements (Huddleston, 2013). Obtaining documents from countries of origin is noted as a particularly cumbersome process that may come at a prohibitive cost, may require travel, as well as translation and certification (Niessen and Huddleston, 2010). Security concerns can also make it impossible for persons from certain countries and stateless persons to contact authorities or travel to their country of origin (ibid.). The European Commission's Handbook on Integration states that flexibility and clear guidelines for exemptions can prevent multiple requests for documents and inter-agency miscommunications that may delay procedures and lead to the expiration of documents with a limited validity before a decision can be taken (Ibid.).

Documentation requirements for applicants for Irish citizenship are not set out in legislation, however the required documentation is set out in the application forms.

In an assessment of $15 \mathrm{EU}$ countries, Ireland was found to have more demanding documentation requirements than most (Migration Policy Group and Immigrant Council of Ireland, 2013). It was noted that, while authorities automatically obtain information on criminal records and investigations involving the applicant, the process of checking previous identity cards, residence permits, and income records can lead to delays. It was also noted that the requirement for birth certificates and passports to be officially translated and certified can result in additional costs and waiting time for applicants (ibid.).

\section{Identity and nationality}

All applicants must provide evidence of their identity and nationality. Applicants must provide their original current passport and any previous passports held during periods of residence in the State. Applicants must also provide a photocopy of the biometric page of each passport. A certified copy of the applicant's birth certificate, ${ }^{243}$ and a copy of a translation into English by a professional translator if the certificate is not in English or Irish, must also accompany the application. ${ }^{244}$ Applicants must also provide two colour passport photographs taken within 30 days of the date of application and signed and dated on the back by the witness who signs the statutory declaration in the application form. ${ }^{245}$ a notary public, commissioner for oaths or peace commissioner, who must make a photocopy of each document and certify that it is a true copy of the original. 
Applicants may experience practical barriers to applying for naturalisation due to difficulties obtaining the required documentation to verify their identity and nationality, including in the case of refugees (see below in this section: 'Refugees') (Cosgrave, 2011; Mannion, 2016). For example, Arnold (2020) highlighted that it can be difficult to obtain a passport for a child who has never lived in their country of citizenship. Where an applicant for naturalisation is unable to provide the required documentation or supporting documents to prove their identity, the application form states an applicant must provide a full explanation, supported by satisfactory evidence of attempts to obtain such documentation and communication with the relevant authorities or embassy responsible for issuing passports and birth certificates in their country. ${ }^{246}$ Where Immigration Service Delivery is satisfied the lack of documentation is genuinely beyond the applicant's control, the application form states it will suggest alternative means for the applicant to assist in establishing their identity and nationality. ${ }^{247}$

Where an applicant cannot provide a birth certificate issued by the authorities in the country where their birth was registered, the application form states that in certain limited and exceptional circumstances a birth affidavit may be accepted in lieu of a birth certificate, where the applicant can show satisfactory evidence that the certificate is not available and cannot be obtained. ${ }^{248}$ Challenges may arise in obtaining a birth certificate from countries where there are administrative issues or a lack of a birth registration system (Arnold, 2020). The Immigrant Council of Ireland highlighted that the 'exceptional circumstances' in which a birth affidavit may be accepted are not defined and appear to be applied inconsistently (Mannion, 2016).

The Immigrant Council of Ireland points to challenges faced by young people in care in particular, who were reported to experience difficulties accessing original documentation to prove identity, such as in cases where parents or carers had left Ireland, were not contactable or did not cooperate (Mannion, 2016). The Immigrant Council of Ireland recommended that the Minister ensure discretion in processing applications, and allow for the use of birth affidavits, in respect of children who have been in the care of the State, where records made by Tusla (the Child and Family Agency) show there has been no contact with a child's parent(s), and reasonable efforts have been made to establish identity and contact parents and relevant embassies to acquire documentation (Mannion, 2016).

\footnotetext{
246 Immigration Service Delivery, 'Form 8: Application by a person of full Age for naturalisation as an Irish citizen', www.irishimmigration.ie/wp-content/uploads/2019/11/form-CTZ3.pdf; Parliamentary Question [30697/19], 11 July 2019, available at www.justice.ie. 


\section{Residence}

All applicants must also provide documentary evidence of residence.

Both EU and non-EU adult applicants must provide three different proofs of residence for each year of claimed residence, showing the applicant's name, address and date of issue. ${ }^{249}$ Such proof of residence may include a mortgage agreement/statement, a tenancy agreement, household bills, bank statements, letters from Revenue or Department of Employment Affairs and Social Protection, and letters from the applicant's employment. ${ }^{250}$ Form 11 states that rent agreements will only be accepted if accompanied by a Residential Tenancies Board letter. ${ }^{251}$ This guidance is not provided in other forms.

Applicants are also required to provide a letter on headed paper from their current employer showing the date of commencement of employment, if applicable, copies of three recent payslips within the previous six months, and copies of their P60 or tax statement from Revenue for each year of residence claimed. ${ }^{252,253}$ Applicants must also provide copies of all bank statements for three of the previous six months. ${ }^{254}$

Non-EU national applicants must also provide additional documentation specific to their residence permission, a requirement which does not apply to EU nationals. Non-EU nationals must provide evidence of residence permissions that cover a continuous period of 365/366 days in the year immediately prior to the date of application and covering periods totalling four years in the eight-year period before that are required. ${ }^{255}$ Residence permissions are evidenced by immigration stamps in the applicant's passport and letters issued by Immigration Service Delivery indicating residence permissions granted may also be used. ${ }^{256}$ In addition to the original of their current passport and any previous passports valid during periods of residence in Ireland, non-EU applicants must provide a copy of their current Immigrant Registration Card issued by Immigration Service Delivery or Garda www.irishimmigration.ie/wp-content/uploads/2019/11/form-CTZ3.pdf. lbid. Immigration Service Delivery, 'Form 11: Application by a parent or guardian of, or person who is in loco parentis to a minor born in the state who did not at birth have an entitlement to Irish citizenship under Section 6A of the Act of 1956', www.irishimmigration.ie/wp-content/uploads/2019/11/form-CTZ6.pdf. Immigration Service Delivery, 'Form 8: Application by a person of full Age for naturalisation as an Irish citizen', www.irishimmigration.ie/wp-content/uploads/2019/11/form-CTZ3.pdf. From 2019, P60s are no longer issued, with an Employment Detail Summary instead being issued by Revenue to employees.

254 Ibid.

255 Immigration Service Delivery, 'Form 8: Application by a person of full Age for naturalisation as an Irish citizen', www.irishimmigration.ie/wp-content/uploads/2019/11/form-CTZ3.pdf. 
National Immigration Bureau (GNIB). ${ }^{257}$ Non-EU applicants, with the exception of refugees and stateless persons, ${ }^{258}$ must also fill out the online Naturalisation Residency Calculator and attach a copy of this to their application form. ${ }^{259}$ The Naturalisation Residency Calculator allows applicants to check if they have sufficient reckonable residence in Ireland to apply for naturalisation, by filling in the online form with the dates of all reckonable immigration stamps held. ${ }^{260}$

\section{Means of financial support}

While there is no statutory economic requirement for persons applying for naturalisation, an applicant's means of financial support forms part of the overall range of information considered by the Minister when deciding on an application (see Section 4.1.6).

Applicants are required to provide information on their economic status, such as whether they are employed, self-employed, unemployed, retired, studying, or other status. Applicants must provide information on their current employment and employment(s) in the past five years. Applicants must provide information on whether they have received social welfare payments or other State support in the previous three years and, if so, the type and duration of payment or support and reason for obtaining such support. ${ }^{261}$

\section{Referees}

Applicants must provide the details and signature of three Irish citizens to act as referees in their application. ${ }^{262}$ The Citizenship Division of the Department of Justice and Equality noted that contact is made with referees for verification purposes when it is deemed necessary. ${ }^{263}$

\section{Spouses or civil partners}

In addition to the above requirements, applicants applying for naturalisation as a spouse or civil partner of an Irish citizen must submit three different proofs of residence for their spouse or civil partner. A certified copy of their marriage certificate or civil registration must also be provided. Applicants must also submit documentary evidence of their spouse or civil partner's entitlement to Irish

\footnotetext{
257 Immigration Service Delivery, 'Form 8: Application by a person of full Age for naturalisation as an Irish citizen', www.irishimmigration.ie/wp-content/uploads/2019/11/form-CTZ3.pdf. Immigration Service Delivery, 'Become an Irish citizen by naturalisation', www.irishimmigration.ie/citizenship/becomean-irish-citizen-by-naturalisation. Immigration Service Delivery, 'Form 8: Application by a person of full Age for naturalisation as an Irish citizen', www.irishimmigration.ie/wp-content/uploads/2019/11/form-CTZ3.pdf.

260 Department of Justice and Equality, 'Naturalisation Residency Calculator', www.inis.gov.ie/en/INIS/Pages/Naturalisation_Residency_Calculator. Immigration Service Delivery, 'Form 8: Application by a person of full Age for naturalisation as an Irish citizen', www.irishimmigration.ie/wp-content/uploads/2019/11/form-CTZ3.pdf. Ibid.

263 Consultation with Citizenship Division, Immigration Service Delivery, Department of Justice and Equality, January 2020.
} 
citizenship, such as a certified copy of the Irish spouse or civil partner's birth certificate if born in Ireland, foreign birth register entry or the spouse or civil partner's parent's birth certificate if their parent(s) was born in Ireland, naturalisation certificate, or passport page with photograph. ${ }^{264}$

\section{Refugees}

In addition to the above requirements, where applicable, refugees must submit a copy of the letter confirming their refugee status, the original of their passport and any other identity document, and the original of their travel document, if they have one. ${ }^{265}$

At the time of applying for refugee status, an individual must submit their passport to the International Protection Office. People who are recognised as refugees do not have their passport returned to them following a grant of refugee status. ${ }^{266}$ The Minister has stated in the past that use by a refugee of a passport issued by their country of origin can be construed as continuing to avail of the protection of that country, and potentially provide a basis for revocation of refugee status, and, as it would not be correct or logical to create the conditions for revocation, the refugee's passport is retained (see also Arnold, 2019). ${ }^{267}$

If an applicant anticipates that their refugee status will present particular difficulties in supplying a current and valid passport, they must provide a detailed note setting out the details of their case and, if appropriate, the Minister may explore other alternatives for applicants to verify their identity. ${ }^{268}$ In practice, refugee applicants are required to swear an affidavit regarding their identity and why they cannot provide evidence of national identity documents. ${ }^{269}$

The website also states that if a refugee's passport is in the possession of Immigration Service Delivery at the time of application, the applicant is asked to include this information with their application, including the specific area within Immigration Service Delivery to which the passport was sent. ${ }^{270}$ In response to a parliamentary question, the Minister has stated that in cases where the applicant

Immigration Service Delivery, 'Form 8: Application by a person of full Age for naturalisation as an Irish citizen', www.irishimmigration.ie/wp-content/uploads/2019/11/form-CTZ3.pdf.

Ibid.

Parliamentary Question [20994/19], 15 May 2019, available at www.oireachtas.ie/en/debates/question/2019-0515/125. Recognised refugees are instead entitled to a refugee travel document in lieu of a passport for travel from and to Ireland.

Ibid.

Immigration Service Delivery, 'Become an Irish citizen by naturalisation', www.irishimmigration.ie/citizenship/becomean-irish-citizen-by-naturalisation; Consultation with Citizenship Division, Immigration Service Delivery, Department of Justice and Equality, January 2020.

Comments received from the external reviewer, October 2020.

Immigration Service Delivery, 'Become an Irish citizen by naturalisation', www.irishimmigration.ie/citizenship/becomean-irish-citizen-by-naturalisation. 
has already submitted a passport to another area of the Irish Naturalisation and Immigration Service (now Immigration Service Delivery), the Citizenship Division will take the necessary steps to secure the passport for appropriate examination and will revert to the applicant if further clarification or documentation is required. ${ }^{271}$

\section{Irish associations}

People applying for naturalisation on the basis of 'Irish associations' must additionally provide certified copies of all documentation proving their Irish associations. These include documents such as a birth certificate and/or marriage certificate or civil partnership agreement, foreign birth registry entry, or naturalisation certificate. ${ }^{272}$

\section{Applications on behalf of children}

A number of residence documentation requirements are common to all applications on behalf of child applicants (Forms 9, 10 and 11). ${ }^{273}$ If applicable, applicants must submit a copy of the letter confirming the child's refugee status. Applications must include original school letters from each school attended by the child from their date of arrival in the State to the date of application, that show details of enrolment dates, periods of attendance and the number of days attended in each school year. If the child has attended school in Ireland for less than three years, applicants must submit a letter from the Department of Employment Affairs and Social Protection stating that the applicant is in receipt of child benefit for their child and the date on which payment commenced, in addition to a letter from their doctor stating that their child is registered with the practice, the date the child was first registered and the dates the child attended the surgery, including the child's Patient Immunisation Record where applicable. If the child is aged 16 and over and a non-EU national, the applicant must submit a copy of the child's current Irish Residence Permit. The applicant must also give their consent in the application to children aged 16 and over being vetted by the National Vetting Bureau. ${ }^{274}$

Parliamentary Question [22699/19], 28 May 2019, available at www.justice.ie/en/JELR/Pages/PQ-28-05-2019-169. Immigration Service Delivery, 'Form 8: Application by a person of full Age for naturalisation as an Irish citizen', www.irishimmigration.ie/wp-content/uploads/2019/11/form-CTZ3.pdf.

Although in the case of applications on behalf of children on the basis of Irish descent or associations, residence documentation requirements only apply if the child is resident in Ireland.

Immigration Service Delivery, 'Form 9: Application for a Certificate of Naturalisation by a naturalised Irish citizen acting on behalf of his/her minor child', www.irishimmigration.ie/wp-content/uploads/2019/11/form-CTZ4.pdf; Immigration Service Delivery, 'Form 10: Application for a Certificate of Naturalisation by a Parent or Guardian acting on behalf of a minor of Irish decent or Irish Associations', www.irishimmigration.ie/wp-content/uploads/2019/11/form-CTZ5.pdf; Immigration Service Delivery, 'Form 11: Application by a parent or guardian of, or person who is in loco parentis to a minor born in the state who did not at birth have an entitlement to Irish citizenship under Section 6A of the Act of 1956', www.irishimmigration.ie/wp-content/uploads/2019/11/form-CTZ6.pdf. 
Additional requirements vary depending on the situation of each child applicant. In an application by a naturalised Irish citizen on behalf of their minor child (Form 9), the naturalised parent, guardian or person acting in loco parentis must submit the original of the child's current passport and any previous passports during residence in the State, together with a photocopy of the biometric page of each passport. A certified photocopy of the child's original birth certificate must be provided. Two colour photographs of the child taken within 30 days of the application must be submitted, with the child's Personal Public Service Number (PPSN) written on the back of the photographs. The applicant must also submit their naturalisation certificate. ${ }^{275}$

In the case of an application on behalf of a child of Irish descent or associations (Form 10), the applicant must submit an original of both the child's and their own current passport. A certified copy of both the applicant and the child's original birth certificate, and a copy of a translation into English if the certificate is in a language other than English or Irish, must be submitted. Two colour passport photographs, with the child's passport number written on the back, must also be submitted. If claiming association by descent, the applicant must provide a certified copy of the birth certificate(s) and marriage certificates, if applicable, of the person(s) through whom they are claiming Irish associations for the child. The applicant must submit a certified copy of either the current passport of the person(s) through whom they are claiming Irish associations for the child if they are alive, or a certified copy of their death certificate if they are deceased. ${ }^{276}$

Applications on behalf of children not entitled to citizenship by birth (Form 11) must include the original of the applicant's current passport and any previous passports that were in date while resident in the State, together with a certified colour photocopy of each passport. The original of the child's current passport and any of the child's previous passports, together with a photocopy of the biometric page of each passport, must be submitted. A certified copy of both the applicant and child's original birth certificate, and a copy of a translation into English if the certificate is in a language other than English or Irish. If a non-EU national, the applicant must submit a copy of their current Irish Residence Permit. Two colour passport photographs of the child, with the child's PPSN on the back of the photographs, must also be included. As in the case of adult applicants, applicants on behalf of children not entitled to citizenship by birth must also submit three different proofs of residence for each year of residence claimed. If the individual applying on behalf of the child is in employment, they must submit a letter from on behalf of his/her minor child', www.irishimmigration.ie/wp-content/uploads/2019/11/form-CTZ4.pdf.

276 Immigration Service Delivery, 'Form 10: Application for a Certificate of Naturalisation by a Parent or Guardian acting on behalf of a minor of Irish decent or Irish Associations', www.irishimmigration.ie/wpcontent/uploads/2019/11/form-CTZ5.pdf. 
their current employer showing the date they started working, copies of three pay slips within the six months prior to the application and copies of their P60 or tax statement from Revenue for each year of residence claimed. For periods of unemployment or study, applicants must submit a letter from the Department of Employment Affairs and Social Protection stating the dates and types of benefits claimed and three recent receipts of payment from the Department of Employment Affairs and Social Protection, if applicable, and a doctor's letter showing the date the applicant first registered with the practice, and dates of attendance for each year. If the applicant is or was attending school, college, or a course, an official letter must be submitted showing the date of registration, periods of attendance and the date education ceased. Non-EU national applicants must also submit a copy of the completed online residence calculator. ${ }^{277}$

\subsubsection{Naturalisation fees}

Naturalisation fees are governed by the Irish Nationality and Citizenship Regulations 2011. ${ }^{278}$ Naturalisation applicants must pay an application fee and certification fee. ${ }^{279}$ Both fees are payable by bank draft only. ${ }^{280}$

Applicants have been required to pay a $€ 175$ application fee since 2011. ${ }^{281}$ Applicants granted citizenship must also pay a certification fee, which varies for different groups. The adult certification fee is $€ 950$. The fee is reduced to $€ 200$ for a widow/widower of an Irish citizen and where an application is made on behalf of a child. The Minister stated that the current level of fees was introduced to reflect the effort and cost involved in processing applications for a certificate of naturalisation. ${ }^{282}$ Applicants may also incur additional costs for certification and translation of documents accompanying the naturalisation application.

The current level of certification fees payable were introduced in 2008, in line with inflation since the last fee change in $1993 .{ }^{283}$ The certification fee for an adult increased from $€ 634.87$ to $€ 950$, while the fee for a minor, spouse of a naturalised

277 Immigration Service Delivery, 'Form 11: Application by a parent or guardian of, or person who is in loco parentis to a minor born in the state who did not at birth have an entitlement to Irish citizenship under Section 6A of the Act of 1956', www.irishimmigration.ie/wp-content/uploads/2019/11/form-CTZ6.pdf. Irish Nationality and Citizenship Regulations 2011 (S.I. No. 569/2011). Immigration Service Delivery, 'Become an Irish citizen by naturalisation', www.irishimmigration.ie/citizenship/become-an-irish-citizen-by-naturalisation; Irish Nationality and Citizenship Regulations 2011 (S.I. No. 569/2011).

280 Immigration Service Delivery, 'Become an Irish citizen by naturalisation', www.irishimmigration.ie/citizenship/become-an-irish-citizen-by-naturalisation. Immigration Service Delivery, 'Become an Irish citizen by naturalisation', www.irishimmigration.ie/citizenship/become-an-irish-citizen-by-naturalisation; Irish Nationality and Citizenship Regulations 2011 (S.I. No. 569/2011). 
Irish citizen, and widow/widower of an Irish citizen increased from $€ 126.97$ to $€ 200$.

Applicants with refugee and programme refugee status, and applicants who are stateless, are exempt from paying the certification fee. ${ }^{284}$ Although Ireland has not signed or ratified the European Convention on Nationality, the Department of Justice and Equality reported that the fee waiver adheres to Ireland's responsibilities under the European Convention on Nationality (Department of Justice and Equality, 2019). ${ }^{285}$ This is also in line with Ireland's obligations under the 1954 Convention relating to the Status of Stateless Persons, which provides that the host State should facilitate the naturalisation of stateless persons as far as possible, in particular by expediting naturalisation procedures and reducing as far as possible the charge and costs of such proceedings. ${ }^{286}$ In spite of the exemptions in place for stateless persons, there is no statelessness procedure in Ireland, which may prevent the recognition of persons as stateless and thus hinder a stateless person's access to fee exemptions for naturalisation in practice (Migration Policy Group and Immigrant Council of Ireland, 2013; UNHCR, 2014; Immigrant Council of Ireland, European Network on Statelessness and Institute on Statelessness and Inclusion, 2015; Arnold, 2020; EMN, 2020b).

Bauböck et al. (2013) note that the cost of applying for citizenship is an indicator of a state's willingness to promote naturalisation among eligible applicants and that high application and certification fees may act as a de facto economic requirement. They found that, at a total cost of $€ 1,125$ for an adult applicant to whom the exceptions do not apply, Ireland charges the third highest fees for an application and grant of citizenship out of 35 European countries examined at the time (ibid.). ${ }^{287}$ Huddleston et al. (2015) also found that Ireland's naturalisation process is one of the most expensive of any major destination country, noting that the fee is higher than in Australia, Canada, New Zealand and the United States. The EMN (2020a) study on Pathways to citizenship for third-country nationals in the EU found that costs associated with applying for naturalisation vary significantly across EU Member States and the UK, ranging from no fee to $€ 1,500$. Of $24 \mathrm{EU}$ Member States examined, Ireland ranks among the four highest in terms of total application and certification fees, along with the UK, Austria and the Netherlands (EMN, 2020).

284 Immigration Service Delivery, 'Become an Irish citizen by naturalisation', www.irishimmigration.ie/citizenship/become-an-irish-citizen-by-naturalisation; Irish Nationality and Citizenship Regulations 2011 (S.I. No. 569/2011). acquisition of its nationality for stateless persons and recognised refugees, among others.

2861954 Convention relating to the Status of Stateless Persons, Article 32.

287 The countries examined include the 27 EU Member States, Iceland, North Macedonia, Montenegro, Norway, Russia, Switzerland, Turkey and the United Kingdom. 
Becker and Cosgrave (2013) stated that the fees in Ireland could act as a deterrent to potential applicants. The media has also highlighted that potential applicants view fees as a barrier to acquiring citizenship (Pollak, 2020a). The Immigrant Council of Ireland recommended a review of fees, paying particular attention to the situation of vulnerable or low income individuals or families who may struggle to meet the financial requirement, and the introduction of the possibility of a fee exemption for such groups (Immigrant Council of Ireland, 2015). Members of parliament have raised the issue of the amount of fees associated with applying for naturalisation in the Oireachtas and have asked the government if it would consider introducing reduced fees, such as for those on low income or senior citizens. $^{288}$

The Migrant Integration Strategy 2017-2020 highlighted that the issue of naturalisation fees arose in the strategy's consultation process. Action 10 of the strategy states that naturalisation fees will be kept under regular review to ensure the costs are reasonable and do not deter qualified applicants (Department of Justice and Equality, 2017). The Progress Report to Government published in 2019 reported that naturalisation fees are reviewed annually, taking into consideration feedback from those who have naturalised and are currently in, or considering entering, the naturalisation process. The Department stated there were no plans to change the fees at that time (Department of Justice and Equality, 2019). ${ }^{289}$ The Department also highlighted the fact that fees have not been raised in almost ten years despite enhancements to the application process, including the introduction of citizenship ceremonies. ${ }^{290}$

\subsubsection{Application supports}

The Department of Justice and Equality provides information on its website concerning applications for citizenship. ${ }^{291}$ The Department reported the website underwent a review to ensure plain English is used and the material available is accessible and understandable. ${ }^{292}$ The Department's Citizenship Division operates an enquiries phone line and an email helpdesk. ${ }^{293}$ The Citizenship Division stated it also provides information and clarification on a daily basis to governmental and non-governmental agencies and public representatives. ${ }^{294}$

Parliamentary Question [48160/17], 14 November 2017, available at www.oireachtas.ie/en/debates/question/201711-14/191/; Parliamentary Question [31668/18], 12 July 2018, available at www.justice.ie/en/JELR/Pages/PQ-12-072018-207; Parliamentary Question [29662/19], 9 July 2019, available at www.justice.ie/en/JELR/Pages/PQ-09-07-2019301.

See also Parliamentary Question [48160/17], 14 November 2017, available at www.oireachtas.ie/en/debates/question/2017-11-14/191; Parliamentary Question [31668/18], 12 July 2018, available at www.justice.ie/en/JELR/Pages/PQ-12-07-2018-207; Parliamentary Question [29662/19], 9 July 2019, available at www.justice.ie/en/JELR/Pages/PQ-09-07-2019-301.

290 Comments received from the Department of Justice and Equality, October 2020.

291 Department of Justice and Equality, 'Citizenship', www.irishimmigration.ie/citizenship.

292 Consultation with Citizenship Division, Immigration Service Delivery, Department of Justice and Equality, January 2020.

293 Ibid.

294 Ibid. 
Supports are provided to naturalisation applicants by a range of NGOs in Ireland. In March 2011, the New Communities Partnership (NCP) set up the Citizenship Application Support Service (CASS), with the assistance of funding from the then Office for the Promotion of Migrant Integration within the Department of Justice. The CASS provides information and a 'one-to-one' advice service for persons wishing to apply for naturalisation. The scheme was established to ensure the submission of high quality applications and reduce delays in processing times through information provision to applicants. ${ }^{295}$ The CASS and supports provided by other NGOs were reported as helping to reduce the error rate among applications (McGinnity et al., 2011; 2013). The Department of Justice and Equality reported that funding to the Service ceased in 2017. ${ }^{296}$ The CASS continues to provide assistance to applicants but reported that it introduced a small fee for people availing of its service since October 2017 (New Communities Partnership, 2019).

\subsection{PROCESSING APPLICATIONS}

When an application has been received, Citizenship Division checks that the applicant has used the correct version of the application form, paid the application fee, completed the statutory declarations, and submitted all required documents. ${ }^{297}$ Once an application is deemed valid, Citizenship Division issues the applicant with an acknowledgment letter stating that the applicant has passed the initial examination stage. ${ }^{298}$ Where documents are missing, the applicant may be given up to 28 days to provide them, otherwise the application will be deemed ineligible or refused. ${ }^{299}$

\subsubsection{Decision-making procedure}

Citizenship Division reported that the decision-making process is broken down into four main stages. First, the identity of the applicant is verified, usually through their passport. ${ }^{300}$ The second stage involves assessing whether the applicant has satisfied the residence requirement. ${ }^{301}$ Residence permissions are examined in the case of non-EU nationals, while employment records and other proofs of residence are the primary source of proof for EU applicants. ${ }^{302}$

New Communities Partnership, 'Irish Citizenship Application Support Service: Aims', www.newcommunities.ie/services2/cass/aims.html. Immigration Service Delivery, 'Become an Irish citizen by naturalisation', www.irishimmigration.ie/citizenship/become-an-irish-citizen-by-naturalisation. Citizens Information, 'Becoming an Irish citizen through naturalisation', www.citizensinformation.ie/en/moving_country/irish_citizenship/becoming_an_irish_citizen_through_naturalisation .html. 
Thirdly, the good character assessment is carried out, primarily through reports obtained from An Garda Síochána. ${ }^{303}$ Other government departments and agencies may be contacted for information on the applicant, if deemed necessary. ${ }^{304}$ The Minister reported that officials from the Department and the Revenue Commissioner's Office have collaborated on facilitating the process, through the provision of a specific citizenship option for naturalisation applicants applying for electronic tax clearance on the Revenue website. ${ }^{305}$ In October 2020, the Department announced it would introduce eTax clearance and eVetting for citizenship applicants as part of the increased digitisation programme across Immigration Service Delivery. ${ }^{306}$ The Department stated that the introduction of eVetting would speed up the application process and free up valuable Garda resources being used for the manual vetting process.

The final stage of the decision-making process is the citizenship ceremony which facilitates physical verification of the applicant and the making by the applicant of the oath of allegiance. ${ }^{307}$ When processing is complete, Citizenship Division prepares a submission on the applicant's application for a decision by the Minister. ${ }^{308}$

Becker and Cosgrave (2013) note that it is not clear whether the various checks are commenced as soon as the application is deemed valid, or at a later stage, and whether the necessary checks are done individually or at the same time.

\subsubsection{Processing times and communication with applicants}

Since 2013, the Department of Justice and Equality has stated in its annual reporting that in general it takes six months for a standard application to be processed (Department of Justice and Equality, 2014; 2015; 2016; 2017; Irish Naturalisation and Immigration Service, 2018; 2019). In response to a parliamentary question in 2019, the Minister reported that the average processing time from the date an application was received to the date a decision was made was 6.7 months in 2016, 7.2 months in 2017 and 6.5 months in 2018. ${ }^{309}$

303 lbid

304 Immigration Service Delivery, 'Become an Irish citizen by Naturalisation', www.irishimmigration.ie/citizenship/become-an-irish-citizen-by-naturalisation.

305 Parliamentary Question [6986/20], 20 May 2020, available at www.oireachtas.ie/en/debates/question/2020-0520/506.

306 Department of Justice and Equality, 'Citizenship applicants to sign affidavit of loyalty under temporary COVID-19 measures announced by Minister McEntee', Press Release, 22 October 2020, www.justice.ie/en/JELR/Pages/PR20000245. 
The Department states that processing times can vary depending on the circumstances. ${ }^{310}$ Reasons put forward by the Department include completion of necessary checks, requirements for further documentation from the applicant, awaiting payment of the certification fee, or the applicant not engaging with the Department. ${ }^{311}$ The Department indicated that in more complex cases, it can take up to a year to carry out the necessary checks (Department of Justice and Equality, 2019).

The general time for a standard application to be processed increased in 2020 due in part to the High Court judgment on 'continuous residence' in 2019 and restrictions put in place in light of COVID-19 in 2020. In October 2020, the Minister reported that in general, it takes 12 months for a straightforward application to be processed from the date it is received to the date a decision is made. ${ }^{312}$ The Minister stated that the judgment by the High Court in 2019 in Jones v Minister for Justice and Equality, which led to the suspension of processing of citizenship applications, resulted in significant delays in the processing of naturalisation applications. ${ }^{313}$ The Department also stated that restrictions introduced in light of the COVID-19 pandemic resulted in significant challenges to the delivery of normal service. ${ }^{314}$ As of 20 May 2020, the Department stated that 17,954 applications were being processed, 3,629 (20 per cent) of which were in the process for 24 months or more. ${ }^{315}$ As of September 2020, the Minister reported that approximately 21,000 applications were being processed. ${ }^{316}$

Average processing times reported prior to 2013 were higher. The average processing time stood at 24 months in 2006, ${ }^{317}$ and at 23 months in 2008 (Department of Justice, Equality and Law Reform, 2009) and 2009 (Joyce, 2010). Research conducted by the Immigrant Council of Ireland reported that some applicants had waited for periods of up to 54 months for a decision (Cosgrave, 2011). ${ }^{318}$ The Department subsequently introduced changes to help expedite the

Immigration Service Delivery, 'Become an Irish citizen by naturalisation: Processing,

www.irishimmigration.ie/citizenship/become-an-irish-citizen-by-naturalisation/\#processing.

311 Parliamentary Question [36989/19], 17 September 2019, available at www.oireachtas.ie/en/debates/question/2019$09-17 / 264$.

312 Immigration Service Delivery, 'Become an Irish citizen by Naturalisation', www.irishimmigration.ie/citizenship/become-an-irish-citizen-by-naturalisation (accessed 23 September 2020 ); Parliamentary Question [29377/20], 8 October 2020, available at www.oireachtas.ie/en/debates/question/2020-1008/231.

313 Parliamentary Question [6986/20], 20 May 2020, available at www.oireachtas.ie/en/debates/question/2020-0520/506/\#pq_506.

314 Ibid.

315 Ibid.

316 Parliamentary Question [22808/20], 10 September 2020, available at www.oireachtas.ie/en/debates/question/2020-09-10/44.

317 Parliamentary Question [1069/07], 31 January 2007, available at www.oireachtas.ie/en/debates/debate/dail/2007-01-31/33.

318 See also Salman v Minister for Justice and Equality [2011] IEHC 481. 
processing of naturalisation applications, and that aimed to deal with applications within a period of six months. ${ }^{319}$ As noted in Section 4.3.1, the Department reported that the measures resulted in a significant increase in the number of cases being decided and a reduction in processing times (Department of Justice and Equality, 2012).

Concerns around delays have been highlighted in parliamentary debate, ${ }^{320}$ by NGOs, ${ }^{321}$ legal practitioners, ${ }^{322}$ and in the media (Pollak, 2020b; McCrave, 2020). The Immigrant Council of Ireland stated in 2020 that citizenship applications made by clients routinely take 12 months and more, with clients often experiencing delays of over 24 months. ${ }^{323}$ Legal practitioners have expressed concern at the increased processing times and called for sufficient resources to be deployed to the Citizenship Division to ensure applications are processed within an acceptable time limit. ${ }^{324}$ Delays in decision-making have also featured in court cases. The High Court has held in two cases concerning delays, in which the applicants had waited for periods of over 45 and 50 months for a decision, that an unexplained delay was unreasonable and justified the awarding of costs to the applicants. ${ }^{325}$

Applicants have also raised concerns about the lack of information provided to applicants on the processing of applications (Cosgrave, 2011; Pollak, 2020b). Research highlights that while applications and documentation submitted have been generally acknowledged promptly in the past, applicants have expressed frustration at the lack of substantive replies to enquiries regarding the status of their applications, particularly where applications were in the system for long periods of time (Cosgrave, 2011).

In response to a parliamentary question on communication by the Department with applicants, the Minister stated that it is not possible to communicate with each applicant with regard to each stage of the process, due to the volume of applications received; but where additional information is required to support the application, the applicant is written to and the requirements are clearly stated. The Minister stated that 'to engage with each applicant as proposed would 
divert valuable resources away from case processing which remains the key priority'. ${ }^{326}$

Delays were also reported across EU Member States as a challenge in the processing of naturalisation applications (EMN, 2020a). Some countries have set maximum time limits for processing, which serve as a benchmark for administrative practice and a guarantee for applicants (Niessen and Huddleston, 2010). Overall time limits in which applications must be processed are set out in legislation in $15 \mathrm{EU}$ Member States, ${ }^{327}$ with maximum time limits ranging from six months in Austria, the Czech Republic and Estonia, to 12 months in Bulgaria, Greece, Latvia, the Netherlands and Spain, and 48 months in Italy. ${ }^{328}$ However some Member States with prescribed maximum time periods reported that the maximum time periods were not always met for all applications, with reasons reported by Member States including the complexity of cases and poor cooperation by applicants (EMN, 2020a).

\subsubsection{Citizenship ceremonies}

The final stage of the decision-making process is the citizenship ceremony. A day of citizenship ceremonies is held periodically throughout each year. ${ }^{329}$ Ceremonies are presided over by a judge and are usually attended by a government minister. At the ceremony, new citizens make a declaration of fidelity to the nation and loyalty to the State, which is prescribed and provided to the applicant (see Section 4.1.5). ${ }^{330}$ New citizens also receive their certificate of naturalisation at the ceremony. ${ }^{331}$ Consideration is currently being given by the Department of Justice and Equality to introducing a form of citizenship ceremony for children, in cooperation with partners in the education sector and other agencies. ${ }^{332}$

Under arrangements prior to the introduction of ceremonies, a person granted citizenship was required to take an oath before a District Court judge and subsequently received their certificate of naturalisation by post. However, in light of concerns that Ireland lacked appropriate arrangements to give proper recognition to the importance of being granted Irish citizenship, citizenship ceremonies were introduced in 2011. ${ }^{333}$

Parliamentary Question [5694/18], 6 February 2018, available at www.justice.ie/en/JELR/Pages/PQ-06-02-2018-98. Austria, Belgium, Bulgaria, Czech Republic, Estonia, Finland, France, Greece, Italy, Latvia, Lithuania, Luxembourg, the Netherlands, Spain and Slovakia.

Information retrieved from templates published by EMN National Contact Points for the study Pathways to citizenship for third-country nationals in the EU, available at www.ec.europa.eu/home-affairs/what-wedo/networks/european_migration_network/reports_en.

Immigration Service Delivery, 'Citizenship ceremonies', www.irishimmigration.ie/citizenship/citizenship-ceremonies. Irish Nationality and Citizenship Regulations 2011 (S.I. No. 569/2011), Regulation 9(1)(a).

Immigration Service Delivery, 'Citizenship ceremonies', www.irishimmigration.ie/citizenship/citizenship-ceremonies. Consultation with Citizenship Division, Immigration Service Delivery, Department of Justice and Equality, January 2020. Department of Justice and Equality, 'Minister Shatter introduces major changes to citizenship application processing regime', Press Release, 16 June 2011, www.justice.ie/en/JELR/Pages/PR11000088. 
The Department states that in addition to allowing new citizens to make the declaration of fidelity to the Irish nation and loyalty to the State, ceremonies ensure the granting of citizenship is marked by a sense of occasion for new citizens (Department of Justice and Equality, 2012; 2013). In addition, ceremonies are viewed as marking the end of the journey towards Irish citizenship and help the continuing integration of new citizens into Irish society (Irish Naturalisation and Immigration Service, 2019). The first ceremony was held in June 2011 and, as of August 2020, 154 ceremonies have taken place. ${ }^{334} \mathrm{~A}$ virtual citizenship ceremony took place for the first time during the COVID-19 pandemic (see Section 5.5). The introduction of citizenship ceremonies has been welcomed as a positive development in the naturalisation process (McGinnity et al., 2012; Becker and Cosgrave, 2013).

An information booklet is given to new citizens at citizenship ceremonies including information on the right to register to vote and applying for an Irish passport, the words of the national anthem and information about the circumstances under which Irish citizenship can be revoked. ${ }^{335}$ The Public Appointments Service reported it has participated in citizenship ceremonies to promote public sector jobs among new Irish citizens (Arnold et al., 2019). Ceremonies, which have received significant media attention, have also been highlighted for their promotional effect and raising public awareness of the naturalisation process (Becker and Cosgrave, 2013).

Citizenship ceremonies are a mandatory part of the naturalisation procedure in 12 other EU Member States ${ }^{336}$ and the UK, representing the stage in these Member States at which applicants make an oath or declaration to abide by the laws and values of the EU Member State of which they have applied to become a citizen. ${ }^{337}$ In other Member States, ceremonies do not take place, or citizenship ceremonies or events are held at local level and are voluntary for people granted citizenship (EMN, 2020a). (Department of Justice and Equality, 2013); 18 were held in both 2013 and 2014 (Department of Justice and Equality, 2014; 2016); 16 were held in 2015 (Department of Justice and Equality, 2016); nine took place in 2016 (Department of Justice and Equality, 2017); 16 in 2017 (Irish Naturalisation and Immigration Service, 2018); three in 2018 (Irish Naturalisation and Immigration Service, 2019); five in 2019 and six in 2020. Austria, Czech Republic, Denmark, Greece, Hungary, Italy, Latvia, Lithuania, the Netherlands, Romania, Slovakia and Slovenia.

337 Information retrieved from government websites, GLOBALCIT country profiles, and templates published by EMN National Contact Points for the study Pathways to citizenship for third-country nationals in the EU, available at www.ec.europa.eu/home-affairs/what-we-do/networks/european_migration_network/reports_en. 


\subsection{NEGATIVE DECISIONS AND JUDICIAL REVIEW}

No data are available on the reasons for which applicants receive a negative decision on a citizenship application. The Department noted that failure to satisfy the good character requirement, inability to meet the residence criteria and applications for citizenship based on marriages of convenience are among the top reasons for refusals. ${ }^{338}$ The EMN (2020a) found that the most common grounds for refusal of a naturalisation application in Member States were insufficient residence, an applicant's criminal record or failure to satisfy the 'good conduct' requirement, the applicant being deemed a threat to public order or security, and inadequate language skills.

Where the Minister issues the applicant with a decision refusing naturalisation, the Department noted that unsuccessful applicants may make a new application, ensuring that the reasons grounding the refusal of their first application are addressed. ${ }^{339}$

Ireland is one of few European countries that do not grant applicants a right to an appeal mechanism for naturalisation decisions (Migration Policy Group and Immigrant Council of Ireland, 2013; EMN, 2020a). Unsuccessful applicants have a right to apply for judicial review of a negative decision in the High Court, which involves a review of whether the correct procedure was followed and does not involve consideration of the merits of an application. While the High Court may issue an order of certiorari quashing a decision if considered unlawful, the Court cannot set aside the decision of the Minister and replace it with its own decision to grant naturalisation (Becker and Cosgrave, 2013). In practice, some applicants apply for internal administrative review of the decision to refuse naturalisation in order to have the matter reconsidered, prior to issuing judicial review proceedings (Cosgrave, 2011). The Immigrant Council of Ireland reported that on some occasions, administrative review of a refusal has been successfully sought on behalf of an applicant (ibid.).

The courts have held that the Minister is under a duty to provide reasons to unsuccessful applicants, as to not give reasons would hinder the applicant's ability to meaningfully reapply or seek judicial review. ${ }^{340}$ However, the Minister may withhold reasons where doing so is considered by the Minister to be justified. ${ }^{341}$ National security has previously been used as justification for not providing reasons for refusal. ${ }^{342}$ The Supreme Court has held that there is however a duty on public

Interview with Citizenship Division, Immigration Service Delivery, Department of Justice and Equality, July 2019.

Comments received from the Department of Justice and Equality, October 2020.

Mallak v Minister for Justice Equality \& Law Reform [2012] IESC 59.

Ibid.

AP v Minister for Justice and Equality (No. 2) [2014] IEHC 241; KA v Minister for Justice and Equality [2016] IEHC 736. 
law decision-makers to justify a decision not to disclose detailed reasons. In AP v Minister for Justice and Equality, the Court stated the primary objective should be to seek the maximum disclosure possible, and to ensure that, in so far as possible, any restriction on disclosure of reasons was demonstrably the least that was necessary. ${ }^{343}$ The Supreme Court suggested that it was possible to put in place an 'enhanced process' whereby an independent assessment could be made as to whether any version of privileged information relied on in refusing an application for naturalisation could be provided in a way which would not affect State interests to the extent that disclosure should not be required at all. ${ }^{344}$ The possibility of an enhanced process or special advocate procedure was welcomed by practitioners. $^{345}$

In September 2020, the Department announced the establishment of a Single Person Committee of inquiry into the disclosure of material relied upon by the Minister in refusing an application where national security concerns arise. ${ }^{346}$ The establishment of the Single Person Committee introduces a process whereby a naturalisation applicant, whose application has been refused in whole or in part on national security concerns, may apply to the Committee for a decision on the disclosure of the material relied upon by the Minister in refusing their application. ${ }^{347}$ The applicant must communicate to the Committee member their request for a decision in writing within three months of the decision to refuse the naturalisation application. Following a review of the material by the member of the Committee, the member will advise the Minister on the disclosure of the material to the applicant. The member may advise the Minister not to disclose, to partially disclose, or to fully disclose the material. In the case of partial disclosure, the Committee member must provide for the Minister's consideration an indicative wording as to the 'gist' of the information that might be shared with the applicant. The Committee member is appointed by the Minister for a three-year term, with retired Justice John Hedigan being the first member appointed by the Minister on 30 September 2020. ${ }^{348}$ The Department stated that reviews by the Committee would only be carried out for decisions that took place after 30 September $2020 .{ }^{349}$

$A P \vee$ Minister for Justice and Equality [2019] IESC 47 [5.12].

$A P \vee$ Minister for Justice and Equality [2019] IESC 47 [5.18].

Berkeley Solicitors, 'Supreme Court Deliver Judgement in P -V- Minister for Justice and Equality [2019] IESC 47', 6 June 2019, www.berkeleysolicitors.ie/supreme-court-deliver-judgment-in-p-v-minister-for-justice-and-equality-2019-iesc47.

Department of Justice and Equality, 'Minister McEntee announces the establishment of the Single Person Committee of Inquiry', Press Release, 30 September 2020, www.justice.ie/en/JELR/Pages/PR20000222.

The Committee does not provide an avenue to appeal the Minister's decision to refuse an application where national security concerns arise.

Department of Justice and Equality, 'Minister McEntee announces the establishment of the Single Person Committee of Inquiry', Press Release, 30 September 2020, www.justice.ie/en/JELR/Pages/PR20000222.

Immigration Service Delivery, 'Single Person Committee of Inquiry set up to review refusals of Irish Citizenship where National Security concerns arise', 30 September 2020, www.irishimmigration.ie/single-person-committee-of-inquiryset-up-to-review-refusals-of-irish-citizenship-where-national-security-concerns-arise. 


\subsection{REVOCATION OF A CERTIFICATE OF NATURALISATION}

Irish citizenship law provides that naturalised Irish citizens may have their citizenship revoked by the State. Citizenship acquired at birth cannot be revoked.

The revocation of citizenship, and particularly the conditions under which a state can legitimately revoke citizenship, has received renewed attention internationally (Lenard, 2016; Honohan, 2020). Legal practitioners have observed an increase in individuals who acquired Irish citizenship through naturalisation receiving notices from the Department of Justice and Equality (the Department) of the intention of the Minister for Justice and Equality (the Minister) to revoke their citizenship.

Section 19 of the Irish Nationality and Citizenship Act 1956 (as amended) (the 1956 Act) states that the Minister may revoke a certificate of naturalisation if satisfied that:

- naturalisation was procured by fraud, misrepresentation, or concealment of material facts or circumstances; or

- the person to whom it was granted has shown himself to have failed in his duty of fidelity to the nation and loyalty to the State; or

- except in the case of naturalisation granted to a person of Irish descent or associations, the person has been ordinarily resident outside the State for a continuous period of seven years without reasonable excuse and has not registered annually their name and declaration of intention to retain Irish citizenship in the prescribed way; or

- the person is also a citizen of a country at war with Ireland; or

- the person has acquired another citizenship, other than through marriage or civil partnership.

Before revoking a certificate of naturalisation, the Minister must give notice to the naturalised citizen of the Minister's intention to revoke the certificate, stating the grounds for the decision and the right of the naturalised citizen to apply to the Minister for an inquiry as to the reasons for revocation. ${ }^{350} \mathrm{On}$ an application for an inquiry, the Minister must refer the case to a Committee of Inquiry appointed by the Minister and the Committee must report its findings to the Minister. ${ }^{351}$ The Committee must consist of a chairman with judicial experience and other persons the Minister considers fit. ${ }^{352}$ 
While an individual may apply for judicial review of a decision made by the Minister to revoke citizenship, there is no right to appeal a decision. ${ }^{353}$

The 1961 Convention on the Reduction of Statelessness provides that State parties must not deprive a person of their nationality if such deprivation would render them stateless. ${ }^{354}$ Ireland has ratified the 1961 Convention; however in accordance with the Convention's provisions, Ireland made a reservation to the Convention stating that Ireland reserves the right to deprive a naturalised Irish citizen of their citizenship where the person has 'by any overt act, shown himself to have failed in his duty of fidelity to the nation and loyalty to the State' ${ }^{355}$ Irish citizenship law does not contain provisions preventing revocation where the individual does not have the right to the citizenship of any other country, and revocation would therefore render them stateless. Legal practitioners have highlighted this to be a flaw in Irish law. ${ }^{356}$ The United Nations High Commissioner for Refugees (UNHCR) recommended the introduction of a provision in Irish citizenship law preventing the revocation of citizenship where this would render a person stateless (UNHCR, 2014). The Immigrant Council of Ireland, European Network on Statelessness and Institute on Statelessness and Inclusion (2015) also recommended the introduction of safeguards to prevent the revocation of naturalisation certificates where this would give rise to statelessness.

\subsubsection{Committee of Inquiry into revocations}

In 2014, the Minister established a Committee of Inquiry to consider revocations of naturalised citizens and make recommendations to the Minister. ${ }^{357}$ The Minister reported that the Committee convened for the first time in 2018. ${ }^{358}$

As of 20 May 2020, the Minister indicated a total of five revocations have taken place since 2010, arising from voluntary revocation or information coming to light regarding identity. ${ }^{359}$ The Minister also stated that seven hearings by the Committee of Inquiry have taken place, and seven reports in respect of eight

353 Damache v Minister for Justice and Equality, Ireland and the Attorney General [2020] IESC 63.

3541961 Convention on the Reduction of Statelessness, Article 8(1).

355 United Nations Treaty Collection, 'Chapter V Refugees and Stateless Persons: 4. Convention on the Reduction of Statelessness', https://treaties.un.org/pages/ViewDetails.aspx?src=TREATY\&mtdsg_no=V-4\&chapter=5.

356 Sinnott Solicitors, 'Revocation of Irish citizenship', 10 June 2020, https://sinnott.ie/revocation-of-irish-citizenship.

357 Parliamentary Question [5575/20], 20 May 2020, available at www.oireachtas.ie/en/debates/question/2020-0520/432/\#pq_432.

358 Parliamentary Question [4199/19], 29 January 2019, available at www.oireachtas.ie/en/debates/question/2019-0129/263.

359 Parliamentary Question [5575/20], 20 May 2020, available at www.oireachtas.ie/en/debates/question/2020-0520/432/\#pq_432. 
applicants have been issued, since the Committee's initial formation in 2014 and its first hearing in December 2018. ${ }^{360}$

\subsubsection{Constitutionality of revocation procedure}

Recent court proceedings have successfully challenged the constitutionality of the procedure to revoke citizenship. In Damache v Minister for Justice and Equality, ${ }^{361}$ the applicant, who became an Irish citizen through naturalisation in 2008, was convicted of conspiring to materially assist a terrorist organisation in 2018 in the United States. As a result of the conviction, the Minister informed the applicant of his intention to revoke the applicant's Irish citizenship, on the grounds that the applicant had shown himself to have failed in his duty of loyalty and fidelity to the State. In 2019, the applicant filed judicial review proceedings, seeking to quash the Minister's notice to revoke his citizenship, seeking an order prohibiting the Minister from revoking his citizenship, and a declaration that section 19 of the 1956 Act is unconstitutional and incompatible with the State's obligations under EU law and the European Convention on Human Rights. The High Court refused the relief sought by the applicant, however put a stay on the revocation of the applicant's citizenship to allow for an appeal. The applicant subsequently appealed to the Supreme Court.

On 14 October 2020, in Damache v Minister for Justice and Equality, Ireland and the Attorney General, ${ }^{362}$ the Supreme Court held that section 19 of the 1956 Act is unconstitutional. The Court observed that that the loss of citizenship is 'a matter of grave significance' to the individuals concerned. ${ }^{363}$ Loss of citizenship entails the loss of constitutional rights to which citizens are entitled, the loss of entitlement to an Irish passport, and entails the risk of deportation due to the person reacquiring their status as a non-national. For non-EU nationals, loss of citizenship also entails loss of EU citizenship and the rights that flow from that status. ${ }^{364}$

The Supreme Court stated that the process provided for in section 19 of the 1956 Act does not provide the procedural safeguards required to meet the high standards of natural justice that apply to a person facing the revocation of their citizenship, due to the absence of an impartial and independent decision-maker. ${ }^{365}$ The Court stated that, due to the importance of the status of citizenship and the consequences that revocation of a certificate of naturalisation may have on an individual, the process by which citizenship may be revoked must be a robust Parliamentary Question [5575/20], 20 May 2020, available at www.oireachtas.ie/en/debates/question/2020-0520/432/\#pq_432. 
process that properly balances the rights of the State to make the decision with the rights of the individual, and must observe minimum procedural standards. ${ }^{366}$

The Department stated that the Minister is carefully considering the detail of the Supreme Court judgment and any issues arising. ${ }^{367}$

\subsection{MEASURES ADOPTED DURING COVID-19 RESTRICTIONS}

As a result of the COVID-19 pandemic many Member State authorities suspended part or all of their normal activities with respect to procedures for citizenship applications. While some Member States, such as Estonia and Sweden, reported that the continuation of services was possible due to fully digitised procedures, delays were reported in processing applications, citizenship ceremonies and holding language/civic exams linked to citizenship, due to restrictions arising from COVID-19 (EMN, 2020a).

The Department reported that restrictions in light of the COVID-19 pandemic resulted in Immigration Service Delivery's Citizenship Division experiencing significant disruption in the delivery of its core functions. ${ }^{368}$ Immigration Service Delivery published a set of frequently asked questions (FAQs), providing information on immigration-related queries, including in relation to citizenship. In initial versions of the FAQs published in April 2020, applicants were told not to send passports or other valuable documentation until further notice (Immigration Service Delivery, 2020a). Later versions of the FAQs published in July 2020 advised applicants to strongly consider delaying submission of citizenship applications until Phase 4 of the Government's Roadmap for Reopening Society and Business, initially set to occur from mid-July 2020 (Immigration Service Delivery, 2020b). The FAQs highlighted that, due to the restrictions imposed by COVID-19, unprecedented delays were occurring in the issuing of acknowledgment receipts and the processing and return of documentation, and it was not possible to guarantee the prompt return of original documents (Immigration Service Delivery, 2020b).

Some legal practitioners submitted it was unacceptable to expect applicants who have accumulated the required residence and are eligible to apply for citizenship to delay the submission of applications and stated Citizenship Division should continue accepting applications. ${ }^{369}$ Practitioners stated that the initial approach of accepting applications for processing but directing applicants not to submit original 
passports was an acceptable approach, and allowed applicants to continue to submit applications in order to take their place in the queue. ${ }^{370}$ The move to Phase 4 was delayed on 15 July to 10 August 2020, further delayed on 4 August to 31 August 2020 and further delayed on 18 August to 16 September. ${ }^{371}$ On 28 August the Immigration Service Delivery website stated 'applicants are asked not to submit passports/application forms'. ${ }^{372}$ On 31 August 2020, updated FAQs were issued, which no longer recommended the postponement of submission of naturalisation applications (Immigration Service Delivery, 2020c). On 10 September, the Minister stated in response to a parliamentary question that the Citizenship Division was accepting new applications. ${ }^{373}$

The FAQs also provided clarification on the impact of COVID-19 on eligibility for citizenship. It was stated that a pragmatic approach would be applied to applications made by persons who were absent from the State due to COVID-19 travel restrictions or isolation measures. The FAQs stated the one- and two-month periods of automatic renewal of residence permissions that were adopted by the Department would count as reckonable residence for citizenship purposes, where the applicant already held a type of residence permission that counted as reckonable residence. The FAQs also stated that temporary unemployment due to COVID-19 or receipt of the COVID-19 Pandemic Unemployment Payment would not affect future applications for immigration permission or citizenship and would not exclude applicants from being granted citizenship. The same applied to persons who sought Jobseekers Allowance because the business they were working for ceased trading (Immigration Service Delivery, 2020b).

In light of the COVID-19 pandemic, the full citizenship ceremonies due to take place in July 2020 were postponed. The FAQs stated officials were:

working hard to investigate alternative mechanisms for delivery that protect public health, comply with current restrictions and guidelines and ensure the event is delivered in the dignified and solemn manner appropriate to such an important milestone (Immigration Service Delivery, 2020b).

A pilot virtual ceremony was held on 10 July for 21 citizenship applicants who had opted not to attend the citizenship ceremonies on 2 and 3 March 2020 due to

Sinnott Solicitors, 'Immigration Service Delivery FAQ Document 28th of May 2020 and Citizenship Applications', 29 May 2020, www.sinnott.ie/immigration-service-delivery-faq-document-28th-of-may-2020-and-citizenship-applications.

371 Citizens 'Public health measures for COVID-19', www.citizensinformation.ie/en/health/covid19/public_health_measures_for_covid19.html.

372 Immigration Service Delivery, 'Emergency Return of Passports - Update', 28 August 2020, www.irishimmigration.ie/emergency-return-of-passports-update, accessed 14 September 2020.

373 Parliamentary Question [23138/20], 10 September 2020, available at www.oireachtas.ie/en/debates/question/202009-10/172. 
COVID-19 concerns. ${ }^{374}$ The Department stated that, while shorter than in-person ceremonies, the virtual ceremonies still ensured legal requirements were met and included 'integrity measures', such as identity checks. ${ }^{375}$ The Department stated that a review of the pilot ceremony would take place and, if the pilot is deemed successful, it would provide an avenue by which applicants can be conferred with citizenship over subsequent months. ${ }^{376}$

Following the review of the pilot ceremony, the Department announced on 22 October 2020 that citizenship ceremonies would be temporarily replaced during COVID-19 with a requirement for citizenship applicants to sign an affidavit declaring loyalty to the State and return it to the Department. ${ }^{377}$ On receipt of the returned declaration, the Department stated it would issue a certificate of naturalisation. The Department stated that while it considered the virtual ceremony a success, it did not view virtual ceremonies as feasible to support the demand for ceremonies, with approximately 3,000 eligible applicants awaiting ceremonies. The Department stated it was examining alternative methods of celebrating the acquisition of citizenship by citizens who receive their certificates during COVID-19.

374 Department of Justice and Equality, 'Minister McEntee hosts Virtual Citizenship Ceremony and welcomes Ireland's Newest Citizens', Press Release, 10 July 2020, available at www.justice.ie/en/JELR/Pages/PR20000143. 


\section{CHAPTER 6}

\section{Conclusions}

The acquisition of Irish citizenship provides access to a wide range of rights enjoyed by citizens in Ireland and the EU, in addition to security of status and supporting a sense of belonging in Ireland. The number of people applying for, and acquiring, citizenship through naturalisation in Ireland in recent years has decreased compared to applications and grants in the late 2000s. This mirrors EU-wide trends, which show an overall reduction in the number of people acquiring the citizenship of an EU Member State since 2016.

From a comparative perspective, research has found that Ireland has more favourable conditions for citizenship applicants than other EU Member States. Applicants are required to have five years' residence in Ireland, situating Ireland in a group of 12 EU Member States that seek residence of five years or less. Ireland does not require applicants to renounce their former nationality in order to acquire Irish citizenship, unlike 11 other EU countries. Similarly, applicants are not required to undertake a language or civics test to 'prove' integration into Irish society, a requirement that is in place in a majority of Member States, although the Migrant Integration Strategy 2017-2020 committed to examining the introduction of such tests in Ireland. The introduction of citizenship ceremonies from 2011 has been welcomed as a positive development in the naturalisation process.

Nevertheless, this report documents a number of challenges in relation to conditions for naturalisation and the application process in Ireland.

In 2019, the six-week administrative rule adopted by the Department of Justice and Equality, which provides that applicants cannot leave Ireland for more than six weeks in the year prior to application, came under scrutiny. Criticised by practitioners for being too restrictive, the rule was challenged in the High Court in Jones v Minister for Justice and Equality. The High Court judgment, which held that the six-week rule was unlawful and continuous residence meant unbroken and uninterrupted residence, gave rise to significant concern and disruption in the processing of applications. The Court of Appeal subsequently overturned the judgment and held that the six-week rule was reasonable and pragmatic. Some practitioners highlight that the application of the six-week rule still lacks clarity.

Children who arrive in Ireland before they reach the age of 18 are only eligible to apply for citizenship if they are of Irish descent or associations, or their parents naturalise. Eligible children are not permitted to apply in their own right. Recent case law has clarified that in the context of an application the child must satisfy the 
conditions for naturalisation. However, this may not always be clear on the relevant form. NGOs and practitioners state that provisions concerning age in citizenship law delay access to citizenship for children, which can have an adverse impact on access to third-level education. Access to citizenship for children in the care of the State is particularly unclear. For example, questions arise as to whether a child's social worker can submit an application on their behalf or whether time spent in care can be considered reckonable.

A reduced residence requirement of two years and a waiver of naturalisation fees applies for stateless applicants, in line with international commitments made by Ireland. However, stateless persons face practical obstacles to relying on such provisions in the absence of a formal stateless determination procedure in Ireland.

Revised application forms introduced in 2011 sought to clarify the information required in assessing the 'good character' of applicants, however the requirement continues to give rise to uncertainty for applicants. Failure to satisfy the 'good character' requirement is among the main reasons for refusal of an application.

An appeal mechanism for naturalisation decisions does not exist in Ireland, which is unusual in an EU context.

While measures adopted by the Department in 2012 assisted in clearing the backlog of cases that arose in the late 2000s, processing times are frequently raised as a concern. The Department reported that recent developments have led to further delays in processing. The High Court judgment in Jones v Minister for Justice and Equality, which was subsequently overturned by the Court of Appeal, led to the processing of applications being put on hold in the latter half of 2019, contributing to an increase in average processing times. The COVID-19 pandemic has also led to reduction in capacity to process applications. The six-month average processing time for standard applications had increased to 12 months by mid-2020, with the Immigrant Council reporting that applicants routinely experience delays of more than 12 months.

The cost of the naturalisation process has also been the focus of debate. Ireland's total naturalisation application and certification fees are among the highest in the EU, although the Department highlighted that fees have not increased in almost a decade. Additional costs may be incurred in the certification and translation of documents that must accompany the naturalisation application. 
Such challenges are not unique to Ireland. The EU-wide EMN (2020a) study found that naturalisation can be a lengthy and costly process, with limited available support for citizenship applicants in EU Member States. Supports provided to citizenship applicants by Member States consisted primarily of information provided through online channels or helpdesks (EMN, 2020a).

Whether viewed by Member States as the culmination of the integration process or as facilitating integration, citizenship is a key aspect of integration and therefore integration policy. As a significant proportion of the population now living in Ireland are non-Irish nationals, the acquisition of citizenship and the challenges migrants may face in applying for naturalisation warrant close attention. 



\section{REFERENCES}

Arnold, S. (2019). Beneficiaries of International Protection Travelling to their Country of Origin: Challenges, Policies and Practices in Ireland, European Migration Network, Dublin: Economic and Social Research Institute. https://doi.org/10.26504/sustat73.

Arnold, S. (2020). Pathways to Irish Citizenship: Separated, Stateless, Asylum Seeking and Undocumented Children, Dublin: Ombudsman for Children's Office.

Arnold, S., E. Quinn, S. Groarke, F. McGinnity and C. Durst (2019). Policy and Practice Targeting the Labour Market Integration of Non-EU Nationals in Ireland, European Migration Network, ESRI Research Series No. 89, Dublin: Economic and Social Research Institute. https://doi.org/10.26504/rs89.

Barbulescu, R. (2013). Naturalisation Procedures for Immigrants: Romania, EUDO Citizenship Observatory: Florence: European University Institute, available at http://hdl.handle.net/1814/29795.

Barrett, A., F. McGinnity and E. Quinn (eds.) (2017). Annual Monitoring Report on Integration 2016, Dublin: Economic and Social Research Institute.

Bauböck, R. (2006). 'Citizenship and migration - concepts and controversies', in Bauböck, R. (Ed.) (2006). Migration and Citizenship: Legal Status, Rights and Political Participation. Amsterdam: Amsterdam University Press.

Bauböck, R., I. Honohan, T. Huddleston, D. Hutcheson, J. Shaw and M.P. Vink (2013). Access to Citizenship and its Impact on Immigrant Integration: European Summary and Standards, EUDO Citizenship Observatory, Florence: European University Institute, available at http://hdl.handle.net/1814/29828.

Becker, H. and C. Cosgrave (2013). Naturalisation Procedures for Immigrants: Ireland, EUDO Citizenship Observatory, Florence: European University Institute, available at http://hdl.handle.net/1814/29786.

Bernitz, H. (2013). Naturalisation Procedures for Immigrants: Sweden, EUDO Citizenship Observatory, Florence: European University Institute, available at http://hdl.handle.net/1814/29799.

Charalambidou, N. (2013). Naturalisation Procedures for Immigrants: Cyprus, EUDO Citizenship Observatory, Florence: European University Institute, available at http://hdl.handle.net/1814/29777.

Cosgrave, C. (2011). Living in Limbo: Migrants' Experiences of Applying for Naturalisation in Ireland, Dublin: Immigrant Council of Ireland.

Council of the European Union (1999). 'Presidency Conclusions: Tampere European Council 15 and 16 October 1999', available at www.consilium.europa.eu.

Coutts, S. (2018). Report on Political Participation of Mobile EU Citizens: Ireland, Global Citizenship Observatory, Robert Schuman Centre for Advanced Studies, Florence: European University Institute, available at http://hdl.handle.net/1814/59569.

Department of Justice and Equality (2012). Annual Report 2011, Dublin: Department of Justice and Equality, available at www.justice.ie. 
Department of Justice and Equality (2013). Annual Report 2012, Dublin: Department of Justice and Equality, available at www.justice.ie.

Department of Justice and Equality (2014). Annual Report 2013, Dublin: Department of Justice and Equality, available at www.justice.ie.

Department of Justice and Equality (2016). Annual Report 2014, Dublin: Department of Justice and Equality, available at www.justice.ie.

Department of Justice and Equality (2016). Annual Report 2015, Dublin: Department of Justice and Equality, available at www.justice.ie.

Department of Justice and Equality (2017). The Migrant Integration Strategy: A Blueprint for the Future, Dublin: Department of Justice and Equality, available at www.justice.ie.

Department of Justice and Equality (2018). Annual Report 2016, Dublin: Department of Justice and Equality, available at www.justice.ie.

Department of Justice and Equality (2019). The Migrant Integration Strategy 2017-2020: Progress Report to Government, Dublin: Department of Justice and Equality, available at www.justice.ie.

Department of Justice and Law Reform (2011). Annual Report 2010, Dublin: Department of Justice and Law Reform, available at www.justice.ie.

Department of Justice, Equality and Law Reform (1999). Integration: A two way process. Report to the Minister for Justice, Equality and Law Reform by the Interdepartmental Working Group on the Integration of Refugees in Ireland, Dublin: Department of Justice, Equality and Law Reform.

Department of Justice, Equality and Law Reform (2001). Annual Report 2000, Dublin: Department of Justice, Equality and Law Reform, available at www.justice.ie.

Department of Justice, Equality and Law Reform (2002). Annual Report 2001, Dublin: Department of Justice, Equality and Law Reform, available at www.justice.ie.

Department of Justice, Equality and Law Reform (2003). Annual Report 2002, Dublin: Department of Justice, Equality and Law Reform, available at www.justice.ie.

Department of Justice, Equality and Law Reform (2006a). Annual Report 2005, Dublin: Department of Justice, Equality and Law Reform, available at www.justice.ie

Department of Justice, Equality and Law Reform (2006b). Report on Review of Asylum and Immigration, Dublin: Department of Justice, Equality and Law Reform, available at www.inis.gov.ie/en/inis/vfmreport.pdf/files/vfmreport.pdf.

Department of Justice, Equality and Law Reform (2007). Annual Report 2006, Dublin: Department of Justice, Equality and Law Reform, available at www.justice.ie.

Department of Justice, Equality and Law Reform (2008). Annual Report 2007, Dublin: Department of Justice, Equality and Law Reform, available at www.justice.ie.

Department of Justice, Equality and Law Reform (2009). Annual Report 2008, Dublin: Department of Justice, Equality and Law Reform, available at www.justice.ie.

Department of Justice, Equality and Law Reform (2010). Annual Report 2009, Dublin: Department of Justice, Equality and Law Reform, available at www.justice.ie. 
Dine, M.K. (2013). Naturalisation Procedures for Immigrants: Slovenia, EUDO Citizenship Observatory: Florence: European University Institute, available at http://hdl.handle.net/1814/29797.

EMN (2018). Asylum and Migration Glossary 6.0, Brussels: European Migration Network.

EMN (2020a). Pathways to citizenship for third-country nationals in the EU: EMN Synthesis Report for the EMN Study 2019, Brussels: European Migration Network, available at www.emn.ie.

EMN (2020b). Statelessness in the European Union: EMN Inform, Brussels: European Migration Network, available at www.emn.ie.

EMN (2020c). Long-term resident status in the EU: EMN Inform, Brussels: European Migration Network, available at www.emn.ie.

EMN Bulgaria (2019). Pathways to citizenship for third-country nationals in the EU Member States: Common Template for EMN Study 2019, available at www.ec.europa.eu/emn.

EMN Cyprus (2019). Pathways to citizenship for third-country nationals in the EU Member States: Common Template for EMN Study 2019, available at www.ec.europa.eu/emn.

EMN Czech Republic (2019). Pathways to citizenship for third-country nationals in EU Member States: Czech Republic, Prague: Ministry of Interior of the Czech Republic, available at www.ec.europa.eu/emn.

EMN Estonia (2019). Pathways to citizenship for third-country nationals in the EU Member States: Estonian National Report, Tallinn/Brussels: Tallinn University/European Migration Network, available at www.ec.europa.eu/emn.

EMN Finland (2019). Pathways to citizenship for third-country nationals in the EU Member States: National Contribution from Finland, available at www.ec.europa.eu/emn.

EMN France (2019). Parcours des ressortissants de pays tiers vers la nationalité (Pathways to citizenship for third-country nationals in France). Paris: Ministry of the Interior, available at www.immigration.interieur.gouv.fr/Europe-et-International/Lereseaueuropeen-des-migrations-REM3/Le-reseau-europeen-desmigrationsREM2/Etudes.

EMN Greece (2019). Pathways to citizenship for third-country nationals in the EU Member States. National report: Greece. Brussels: European Migration Network, available at https://ec.europa.eu/homeaffairs/sites/homeaffairs/files/12_greece_pathways_t o_citizenship_en.pdf.

EMN Hungary (2019). Pathways to citizenship for third-country nationals in EU Member States: Hungary. Prague/Brussels: Ministry of Interior/European Migration Network, available at www.ec.europa.eu/emn.

EMN Italy (2019). Percorsi di cittadinanza in Italia per i cittadini di paesi terzi: Studio del Punto di Contatto Italiano European Migration Network (EMN). Rome/Brussels: Ministry of Interior/European Migration Network, available at www.emnitalyncp.it. 
EMN Latvia (2019). 'Pathways to citizenship for third-country nationals in the EU Member States: Common Template for EMN Study 2019', available at www.ec.europa.eu/emn

EMN Luxembourg (2019). Pathways to citizenship for third-country nationals in Luxembourg, Esch-Belval: University of Luxembourg, available at www.ec.europa.eu/emn.

EMN Poland (2019). Pathways to citizenship for third-country nationals in the EU Member States: Common Template for EMN Study 2019, Brussels: European Migration Network, available at www.ec.europa.eu/emn.

EMN Slovakia (2019). Pathways to citizenship for third-country nationals in EU Member States: EMN Study - Questionnaire Form, Bratislava: International Organization for Migration Office in Slovakia, available at www.ec.europa.eu/emn.

EMN Spain (2019). Pathways to citizenship for third-country nationals in the EU Member States: National Contribution from Spain, available at www.ec.europa.eu/emn

Fahey, É., F. McGinnity and E. Quinn (2019). Data for Monitoring Integration: Gaps, Challenges and Opportunities, Dublin: Economic and Social Research Institute and Office for the Promotion of Migrant Integration. https://doi.org/10.26504/bkmnext373.pdf.

Falvey, D. (2019). 'Ireland's citizens in waiting: 16,000 people now in limbo', The Irish Times, 5 October 2019, available at www.irishtimes.com.

Fanning, B. and F. Mutwarasibo (2007). 'Nationals/non-nationals: immigration, citizenship and politics in the Republic of Ireland', Ethnic and Racial Studies, Vol. 30, No. 3, pp. 439-460. https://doi.org/10.1080/01419870701217506.

Fitzgerald, E. (2018). 'The next referendum should be about the nationless born here', Cork Independent, 20 June 2018, available at www.corkindependent.com.

Gil, A.R. and N. Piçarra (2020). Report on Citizenship Law: Portugal, Global Citizenship Observatory, Florence: European University Institute, available at http://hdl.handle.net/1814/66204.

Goodman, S.W. (2010). 'Integration Requirements for Integration's Sake? Identifying, Categorising and Comparing Civic Integration Policies', Journal of Ethnic and Migration Studies, Vol. 36, No. 5, pp. 753-772. https://doi.org/10.1080/13691831003764300.

Górny, A. and D. Pudzianowska (2013). Country Report: Poland, EUDO Citizenship Observatory, Florence: European University Institute, available at http://hdl.handle.net/1814/19631.

Groarke, S., M. Polakowski, E. Quinn and F. McGinnity (2020). Supporting integration? International practices on civics and language requirements linked to naturalisation: Policy implications for Ireland, Dublin: Economic and Social Research Institute and Department of Justice and Equality. https://doi.org/10.26504/bkmnext398.

Handoll, J. (2012). Country Report: Ireland, EUDO Citizenship Observatory, Florence: European University Institute, available at http://hdl.handle.net/1814/19618. 
Hilliard, M. (2018a). 'Six-week rule disqualifying Irish citizenship 'could be unlawful', The Irish Times, 27 January 2019, available at www.irishtimes.com.

Hilliard, M. (2018b). 'Woman is denied Irish citizenship over holiday in France', The Irish Times, 12 January 2018, available at www.irishtimes.com.

Hilliard, M. (2018c). 'Government rethinks case of mother denied citizenship over family holidays', The Irish Times, 27 April 2018, available at www.irishtimes.com.

Home Office (2019). 'MN1 Registration as a British citizen - A guide about the registration of children under 18', available at www.gov.uk/government/publications/formmn1-guidance.

Honohan, I. (2007). 'Bounded Citizenship and the Meaning of Citizenship Laws: Ireland's Ius Soli Citizenship Referendum', in Brown, N. and L. Cardinal (eds) (2007). Managing Diversity: Practices of Citizenship in Australia, Canada and Ireland, Ottawa: University of Ottawa Press.

Honohan, I. (2010). 'Citizenship Attribution in a New Country of Immigration: Ireland', Journal of Ethnic and Migration Studies, Vol. 36, No. 5, pp. 811-827. https://doi.org/10.1080/13691831003764359.

Honohan, I. (2020). 'Just what's wrong with losing citizenship? Examining revocation of citizenship from a non-domination perspective', Citizenship Studies, Vol. 24, No. 3, pp. 355-370. https://doi.org/10.1080/13621025.2019.1700045.

Horwath Consulting Ireland, Rambøll Management and Matrix Knowledge Group (2008). Final report to Office of the Minister for Integration and the Department of Education \& Science: Development of a national English language policy and framework for legally-resident adult immigrants, available at www.education.ie.

Hoxhaj, R., M. Vink and T. Prokic-Breuer (2019). Immigrant Naturalisation, Employment and Occupational Status in Western Europe, Robert Schuman Centre for Advanced Studies, EUI Working Paper RSCAS 2019/16, Florence: European University Institute, available at http://hdl.handle.net/1814/61165.

Huddleston, T. (2013). The naturalisation procedure: Measuring the ordinary obstacles and opportunities for immigrants to become citizens, RSCAS Policy Paper 2013/16, EUDO Citizenship Observatory, Florence: European University Institute, available at http://hdl.handle.net/1814/28122.

Huddleston, T., J. Niessen and J. Dag Tjaden (2013). Using EU Indicators of Immigrant Integration: Final Report for Directorate-General for Home Affairs. Brussels: European Commission.

Huddleston, T., Ö. Bilgili, A. Joki and Z. Vankova (2015). Migrant Integration Policy Index 2015, Barcelona/Brussels: Barcelona Centre for International Affairs and Migration Policy Group, available at www.mipex.eu.

Human Rights Commission (2004). Observations on the Proposed Referendum on Citizenship and on the $27^{\text {th }}$ Amendment to the Constitution Bill 2004, available at www.ihrec.ie.

Immigrant Council of Ireland (2015). Submission to Chairman of EU Affairs Dominic Hannigan: Realising integration through access to rights, justice and services. Dublin: Immigrant Council of Ireland, available at www.immigrantcouncil.ie. 
Immigrant Council of Ireland (2016). Submission to the Migrant Workers' Committee and Committee on the Rights of the Child Joint General Comment on the Human Rights of Children in the Context of International Migration. Dublin: Immigrant Council of Ireland, available at www.ohchr.org.

Immigrant Council of Ireland (2018). INIS Consultation on the Immigration Registration of Foreign National Children. Dublin: Immigrant Council of Ireland, available at www.immigrantcouncil.ie.

Immigrant Council of Ireland, European Network on Statelessness and Institute on Statelessness and Inclusion (2015). Joint Submission to the Human Rights Council at the 25th Session of the Universal Periodic Review: Ireland, available at www.immigrantcouncil.ie.

Immigration Service Delivery (2020a). 'Impact of COVID-19 on Immigration and International Protection: Frequently Asked Questions', version accessed 27 April 2020, Dublin: Department of Justice and Equality.

Immigration Service Delivery (2020b). 'Impact of COVID-19 on Immigration and International Protection: Frequently Asked Questions', version accessed 8 July 2020, Dublin: Department of Justice and Equality.

Immigration Service Delivery (2020c). 'Impact of COVID-19 on Immigration and International Protection: Frequently Asked Questions', version updated 31 August 2020, Dublin: Department of Justice and Equality.

Irish Human Rights and Equality Commission (2020). 'Damache $v$ Minister for Justice and Equality, Ireland and the Attorney General: Outline Submissions on behalf of the Amicus Curiae', available at www.ihrec.ie.

Irish Naturalisation and Immigration Service (2016). Immigration in Ireland: Annual Review 2015. Dublin: Department of Justice and Equality, available at www.justice.ie.

Irish Naturalisation and Immigration Service (2017). Immigration in Ireland: Annual Review 2016. Dublin: Department of Justice and Equality, available at www.justice.ie.

Irish Naturalisation and Immigration Service (2018a). Immigration in Ireland: Annual Review 2017. Dublin: Department of Justice and Equality, available at www.justice.ie.

Irish Naturalisation and Immigration Service (2018b). Service Improvement Plan 2018-2020. Dublin: Department of Justice and Equality, available at www.inis.gov.ie.

Irish Naturalisation and Immigration Service (2019). Immigration in Ireland: Annual review statistics 2018. Dublin: Department of Justice and Equality, available at www.inis.gov.ie.

Joyce, C. (2010). Annual Policy Report on Migration and Asylum 2009: Ireland. European Migration Network, Dublin: Economic and Social Research Institute.

Kelly, E., S. McGuinness, P. O' Connell, A. González Pandiella and D. Haugh (2016). 'How did Immigrants fare in the Irish Labour Market over the Great Recession?' OECD Economics Department Working Papers, No. 1284, Paris: OECD Publishing. https://doi.org/10.1787/18151973.

Kelly, F. (2019). 'Government 'loath' to strip citizenship, Varadkar says', The Irish Times, 26 February 2019, available at www.irishtimes.com. 
Lenard, P.T. (2016). 'Democracies and the Power to Revoke Citizenship', Ethics and International Affairs, Vol. 30, No. 1, pp. 73-91.

Liebig, T. and F. Von Haaren (2011). 'Citizenship and the Socio-Economic Integration of Immigrants and their Children: An Overview across European Union and OECD Countries' in OECD (2011). Naturalisation: A Passport for the Better Integration of Immigrants, Paris: OECD Publishing. https://dx.doi.org/10.1787/97892640991044-en.

Lucey, A. (2018). 'Language test for would-be citizens "under consideration", The Irish Times, 17 May 2018, available at www.irishtimes.com.

Mannion, K. (2016). Child Migration Matters: Children and Young People's Experience of Migration. Dublin: Immigrant Council of Ireland, available at www.immigrantcouncil.ie.

McCárthaigh, S. and M. Carolan (2019). 'Overturning of citizenship ruling hailed as "very important"', The Irish Times, 15 November 2019, available at www.irishtimes.com/news/crime-and-law/overturning-of-citizenship-rulinghailed-as-very-important-1.4083451.

McCrave, C. (2020). "'Since I got the letter, it's just silence": Citizenship delays now a "disincentive" for doctors to stay in Ireland', TheJournal.ie, 9 May 2020, available at www.thejournal.ie.

McGinnity, F., E. Quinn, P. O'Connell and N. Donnelly (2011). Annual Monitoring Report on Integration 2010. Dublin: Economic and Social Research Institute and The Integration Centre.

McGinnity, F., E. Quinn, G. Kingston and P. O'Connell (2012). Annual Monitoring Report on Integration 2011. Dublin: Economic and Social Research Institute and The Integration Centre.

McGinnity, F., E. Quinn, G. Kingston and P. O'Connell (2013). Annual Monitoring Report on Integration 2012. Dublin: Economic and Social Research Institute and The Integration Centre.

McGinnity, F., É. Fahey, E. Quinn, S. Arnold, B. Maître and P. O' Connell (2018a). Monitoring Report on Integration 2018. Dublin: Economic and Social Research Institute and Department of Justice and Equality. https://doi.org/10.26504/bkmnext364.

McGinnity, F., R. Grotti, S. Groarke and S. Coughlan (2018b). Ethnicity and Nationality in the Irish Labour Market. Dublin: Economic and Social Research Institute and Irish Human Rights and Equality Commission. https://doi.org/10.26504/bkmnext369.

McGinnity, F., I. Privalko, É. Fahey, S. Enright and D. O'Brien (2020a). Origin and Integration: A Study of Migrants in the 2016 Irish Census. Dublin: Economic and Social Research Institute and Department of Justice and Equality.

McGinnity, F., S. Enright, E. Quinn, B. Maître, I. Privalko, M. Darmody and M. Polakowski (forthcoming). Monitoring Report on Integration 2020. Dublin: Economic and Social Research Institute and Department of Justice and Equality.

Medborgarskapsutredningen (2013). Det svenska medborgarskapet: Betänkande av Medborgarskapsutredningen [Swedish citizenship: Report of the Citizenship Inquiry], SOU 2013:29, Stockholm: SOU, available at www.regeringen.se/rattsligadokument/statens-offentliga-utredningar/2013/04/sou-201329. 
Mentzelopoulou, M.M. and C. Dumbrava (2018). Acquisition and loss of citizenship in EU Member States: Key trends and issues. Brussels: European Parliamentary Research Service.

Migration Policy Group and Immigrant Council of Ireland (2013). Access to citizenship and its impact on immigrant integration: Handbook for Ireland. EUDO Citizenship Observatory, Florence: European University Institute, available at http://hdl.handle.net/1814/29768.

Mullally, S. (2005). 'Citizenship and family life in Ireland: Asking the question 'Who belongs'?', Legal Studies, Vol. 25, No. 4, pp. 578-600. https://doi.org/10.1111/j.1748-121X.2005.tb00685.x.

New Communities Partnership (2013). Citizenship Application Support Service: Resource pack, available at www.newcommunities.ie.

New Communities Partnership (2019). New Communities Partnership: Annual Activity Report 2018, available at www.newcommunities.ie.

Niessen, J. and T. Huddleston (2010). Handbook on integration for policy-makers and practitioners. Brussels: European Communities. https://doi.org/10.2758/15387.

O'Brien, C. (2018). 'Primary school campaigns to prevent deportation of nine-year-old pupil', The Irish Times, 17 October 2018, available at www.irishtimes.com.

O'Toole, F. (2019). 'The 2004 referendum on citizenship was a disgrace to Irish democracy', The Irish Times, 16 July 2019, available at www.irishtimes.com.

Office of the Minister for Integration (2008). Migration nation: Statement on integration strategy and diversity management. Dublin: Department of Justice, Equality and Law Reform.

Otukoya, B. (2018). 'Super-Citizens: Defining the 'Good Character' Requirement for Citizenship Acquisition by Naturalisation', Hibernian Law Journal, Vol. 17, No. 1, pp. 73-90.

Pilgram, L. (2011). International Law and European Nationality Laws, EUDO Citizenship Observatory, Florence: European University Institute, available at http://hdl.handle.net/1814/19455.

Pogonyi, S. (2013). Naturalisation Procedures for Immigrants: Hungary, EUDO Citizenship Observatory: Florence: European University Institute, available at http://hdl.handle.net/1814/29785.

Pollak, S. (2018). "Bots' used to block immigrants in Ireland from making visa appointments', The Irish Times, 7 September 2018, available at www.irishtimes.com.

Pollak, S. (2020a). 'Citizenship costs hurt young voter participation, says student chief', The Irish Times, 3 February 2020, available at www.irishtimes.com.

Pollak, S. (2020b). 'Over 3,600 people waiting two years for citizenship application to be processed', The Irish Times, 26 May 2020, available at www.irishtimes.com.

Ruškyte, R. (2013). Naturalisation Procedures for Immigrants: Lithuania. EUDO Citizenship Observatory: Florence: European University Institute, available at http://hdl.handle.net/1814/29789. 
Ryan, B. (2004). 'The Celtic Cubs: The Controversy over Birthright Citizenship in Ireland', European Journal of Migration Law, Vol. 6, No. 3, pp. 173-193. https://doi.org/10.1163/1571816043020057.

Sawyer, C. and H. Wray (2014). Country Report: United Kingdom, EUDO Citizenship Observatory, Florence: European University Institute, available at http://hdl.handle.net/1814/19642.

Simonsen, K. (2017). 'Does Citizenship always further immigrants' feeling of belonging to the host nation? A study of policies and public attitudes in 14 Western democracies', Comparative Migration Studies, Vol. 5, No. 3. https://doi.org/10.1186/s40878-017-0050-6.

Stanley, J. (2017). Immigration and Citizenship Law. Dublin: Roundhall.

Stiller, M. (2019). Pathways to Citizenship for Foreigners in Austria. National Contact Point Austria in the European Migration Network, Vienna: International Organization for Migration, available at www.ec.europa.eu/emn.

Taylor, C. (2019). 'Immigrants still facing issues using INIS online booking system', The Irish Times, 17 December 2019, available at www.irishtimes.com.

Thornton, L. (2018a). 'Citizenship and Belonging in Ireland: \#Repealthe27th?', 19 October 2018, available at www.liamthornton.ie.

Thornton, L. (2018b). 'Why it's time for a new approach to Irish citizenship rights', RTÉ Brainstorm, 29 November 2018, available at www.rte.ie.

United Nations High Commissioner for Refugees (2014). 'Scoping paper: Statelessness in Ireland', available at www.refworld.org.

United Nations High Commissioner for Refugees (2019). Handbook on Procedures and Criteria for Determining Refugee Status under the 1951 Convention and the 1967 Protocol relating to the Status of Refugees, Geneva: United Nations High Commissioner for Refugees, available at www.unhcr.org.

Vink, M. and G.-R. de Groot (2010). 'Citizenship Attribution in Western Europe: International Framework and Domestic Trends', Journal of Ethnic and Migration Studies, Vol. 36, No. 5, pp.713-734. https://doi.org/10.1080/13691831003763914. 

TABLE A.1 NATURALISATION APPLICATIONS RECEIVED AND CERTIFICATES ISSUED IN IRELAND 2006-2018

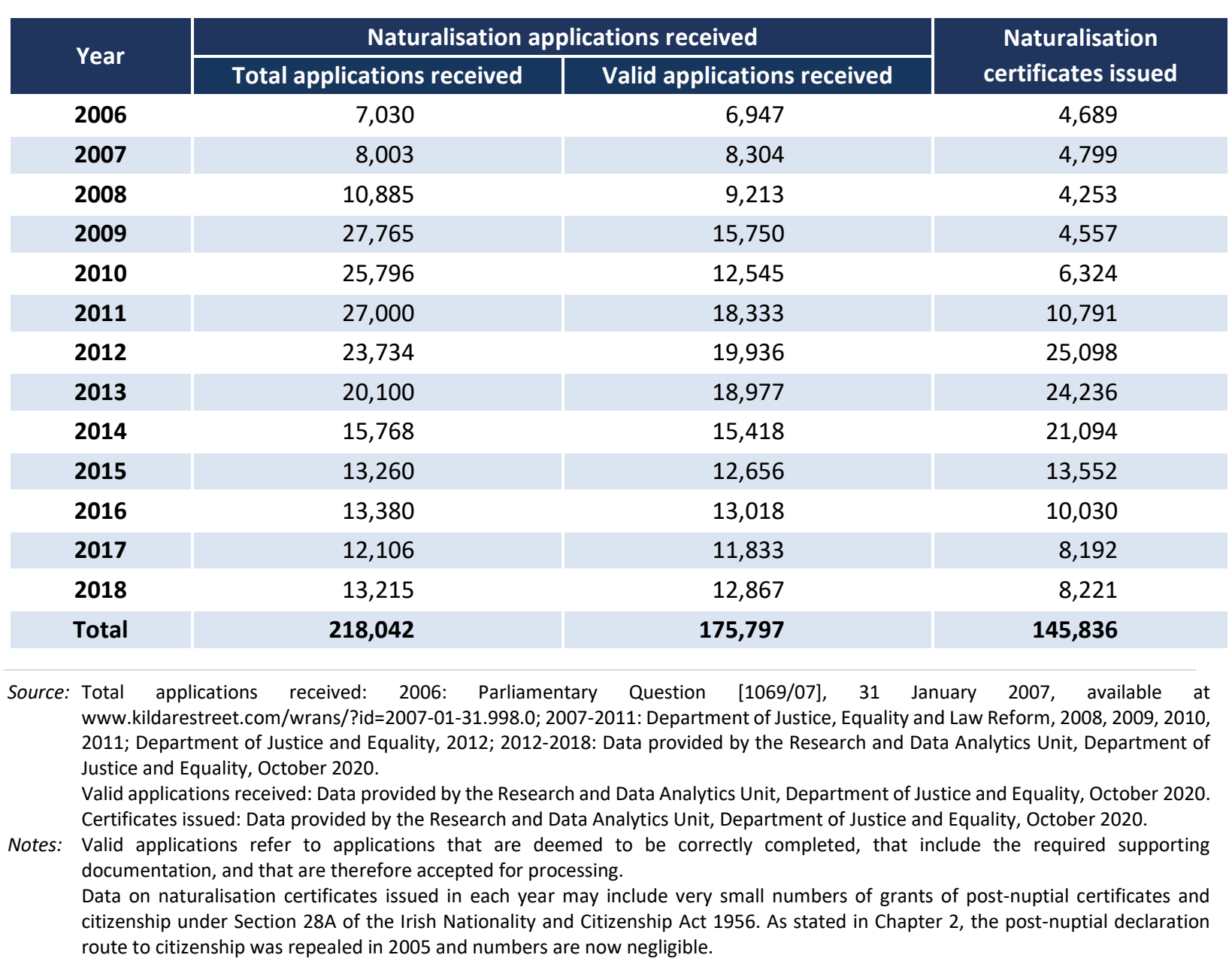


EMN Ireland,

Economic and Social

Research Institute,

Whitaker Square,

Sir John Rogerson's Quay,

Dublin 2, Ireland

Telephone +35318632000

Email emn.irelanddesri.ie

Web www.emn.ie / www.esri.ie

Twitter AEMNIreland

ISBN: 978-0-7070-0549-2

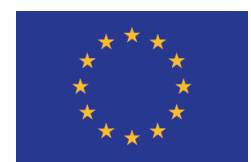

EMN Ireland is funded by the European Union's

Asylum, Migration and

Integration Fund and cofunded by the

Department of Justice
An Roinn Dlí agus Cirt Department of Justice

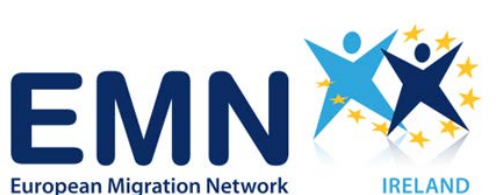

IRELAND
ECONOMIC \& SOCIAL RESEARCH INSTITUTE 